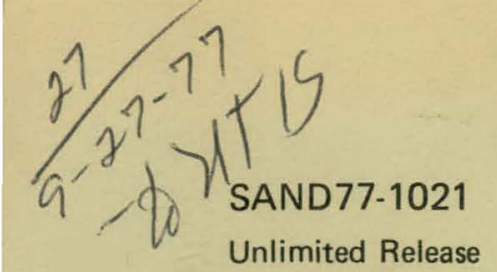

\title{
Environmental Monitoring at the WIPP Site CY 1976
}

Lial W. Brewer, James H. Metcalf

Prepared by Sandia Laboratories, Albuquerque New Mexico 87115

and Livermore, California 94550 for the United States Energy Research

and Development Administration under Contract AT (29-1) 789

Printed August 1977

\section{Sandia Laboratories}




\section{DISCLAIMER}

This report was prepared as an account of work sponsored by an agency of the United States Government. Neither the United States Government nor any agency Thereof, nor any of their employees, makes any warranty, express or implied, or assumes any legal liability or responsibility for the accuracy, completeness, or usefulness of any information, apparatus, product, or process disclosed, or represents that its use would not infringe privately owned rights. Reference herein to any specific commercial product, process, or service by trade name, trademark, manufacturer, or otherwise does not necessarily constitute or imply its endorsement, recommendation, or favoring by the United States Government or any agency thereof. The views and opinions of authors expressed herein do not necessarily state or reflect those of the United States Government or any agency thereof. 


\section{DISCLAIMER}

Portions of this document may be illegible in electronic image products. Images are produced from the best available original document. 
Issued by Sandia Laboratories, operated for the United States Energy Research \& Development Administration by Sandia Corporation.

\section{NOTICE}

This report was prepared as an account of work sponsored by the United States Government. Neither the United States nor the United States Energy Research \& Development Administration, nor any of their employees, nor any of their contractors, subcontractors, or their employees, makes any warranty, express or implied, or assumes any legal liability or responsibility for the accuracy, completeness or usefulness of any information, apparatus, product or process disclosed, or represents that its use would not infringe privately owned rights.

Printed in the United States of America

Available from

National Technical Information Service

U. S. Department of Commerce

5285 Port Royal Road

Springfield, VA 22161

Price: Printed Copy $\$ 5.00 ;$ Microfiche $\$ 3.00$

62 
SA ND77-1021

Unlimited Release

Printed August 1977

ENVIRONMENTAL MONITORING AT THE WIPP SITE CY 1976

Lial W. Brewer

Industrial Hygiene Division, 3311

James H. Metcalf

Instrumentation, Dosimetry and

NTS Projects Division, 3313

Sandia Laboratories, Albuquerque, NM 87115

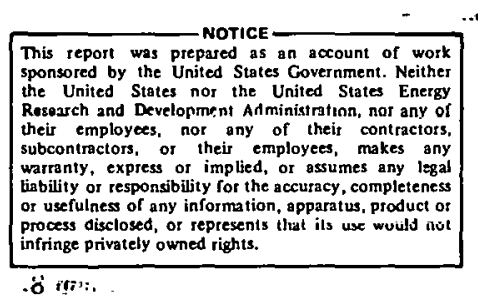

\section{ABSTRACT}

A preliminary study of the radiation background and air quality of the area proposed for the possible construction and operation of a Waste Isolation Pilot Plant was begun early in CY 1976. Measurements of direct radiation and airborne radioactivity are being made, and the levels of air pollutants are being determined to ascertain the present air quality at the site. A description of the monitoring methods used and the data obtained during CY 1976 are presented. 


\section{ACKNOWLEDGMENTS}

The authors wish to express their appreciation to all the personnel who assisted in the acquisition and analysis of the data included in this report:

J. T. Mcllmoyle (1125) and his staff for the fielding and maintenanee of the equipment ueed in this etudy.

Dixie Williams (Fenix and Scisson) and Helen Wolfe (New Mexico Environmental Research Institute) for the acquisition and chemical analysis of the air-quality samples.

T. N. Simmons (3312) for his assistance in data presentation.

D. J. Thompson (3313) for the preparation and evaluation of the thermoluminescent dosimeters used for the background radiation measuremenț,

Al Faychak (9652) for drafting support.

D. Q. Matejka (1151), A. E. McIntyre (1336) and E. J. Meyer (1336) for their assistance in preparation and presentation of the data.

Dr. Marvin H. Wilkening (New Mexico Institute of Mining and Technology), George Werkema (ERDA/ALO), Mel Merritt (1151) Palmer Nelson (1142), and all the Department 3310 personnel who read and commented on the draft version of this report. 
CONTENTS

\begin{tabular}{|c|c|}
\hline & Page \\
\hline Summary & 7 \\
\hline Introduction & 9 \\
\hline Radiation Monitoring Program & 14 \\
\hline Reuter-Stokes Ionization Chamber & 14 \\
\hline Thermoluminescent Dosimeters & 25 \\
\hline Gross Beta Concentrations in Air & 29 \\
\hline Assessment of Dose to Public & 32 \\
\hline Evaluation & 34 \\
\hline Air-Quality Program & 39 \\
\hline Analysis of Samples & 41 \\
\hline Calibration & 43 \\
\hline Results & 44 \\
\hline Discussion & 80 \\
\hline Appendix A - Determination of Sulfur Dioxide & 81 \\
\hline Appendix B - Determination of Nitrogen Dioxide & 87 \\
\hline Appendix C - Determination of Hydrogen Sulfide & 91 \\
\hline Appendix D - Air-Quality Standards & 95 \\
\hline References & 97 \\
\hline Bibliography & 97 \\
\hline
\end{tabular}


Measurements made in the WIPP study area indicate background exposure levels of $8-9 \mu \mathrm{R} / \mathrm{hr}$. These measured data are in good agreement with calculated exposure rates (7.5-9.6 $\mu \mathrm{rad} / \mathrm{hr}$ ). Airborne gross beta concentrations, which were low $\left(0.02 \mathrm{pCi} / \mathrm{m}^{3}\right)$, confirmed the presence of global fallout from the Chinese nuclear tests conducted in the atmosphere during the fall.

The air-quality measurements, except for a few unexplained excursions, were less than State and/or Fereral air-quality standards. 
ENVIRONMENTAL MONITORING AT THE WIPP SITE CY 1976

\section{INTRODUCTION}

The U.S. Energy Research and Development Administration (ERDA) is evaluating a site in southeastern New Mexico for the possible construction and operation of a Waste Isolation Pilot Plant (WIPP). The purpose of this facility would be to test and demonstrate the operational and technical principles of a permanent repository in bedded salt for ERDA-generated low-level transuranic (TRU) and intermediatelevel TRU radioactive waste. High-level waste or waste from commercial sources is excluded from the mission; however, there will be experiments in the WIPP with limited quantities of high-level waste.

The WIPP site is $42 \mathrm{~km}$ (26 miles) east of Carlsbad, New Mexico, and is reached from State Highway 128 (see Figure 1). All the land is Federal or State 1and. In appearance, the site is a gently rolling plain covered by windblown sand and by desert vegetation such as mesquite, sand sage, shinnery oak, and forbs and grasses. The climate is cool in the winter and hot in the summer. Rainfall is about $33 \mathrm{~cm}$ (13 inches) per year. There are no perennial streams in the immediate area; the nearest is the Pecos River $24 \mathrm{~km}$ ( 15 miles) to the west and southwest. The customary surface use of the land is for grazing cattle at a density of about nine head per section.

Early in 1976, measurements of air quality and of background radioactivity were started in the vicinity of the WIPP site. From January 1976 to June 1976, measurements were made at the AEC \#8 drilling pad in Section 11, T 22S, R $31 \mathrm{E}$. In June the station was relocated to the old Badger well site in Section 15 (see Figure 2). At each of these locations a meteorological station was established that consisted of instrumentation for measuring such parameters as wind, temperature, barometric pressure, precipitation; a trailer for recording equipment; and portable diesel generators to provide electrical power for the station. As a part of this on-site meteo- 
rological program, radiation background and air-quality measurements are being made. These background studies, which are only preliminary at present, will be expanded in the years before the facility becomes operational so that we may develop a better understanding of the natural variability of the radiation background and the regional air quality. Figure 3 is a photograph of the present station. 


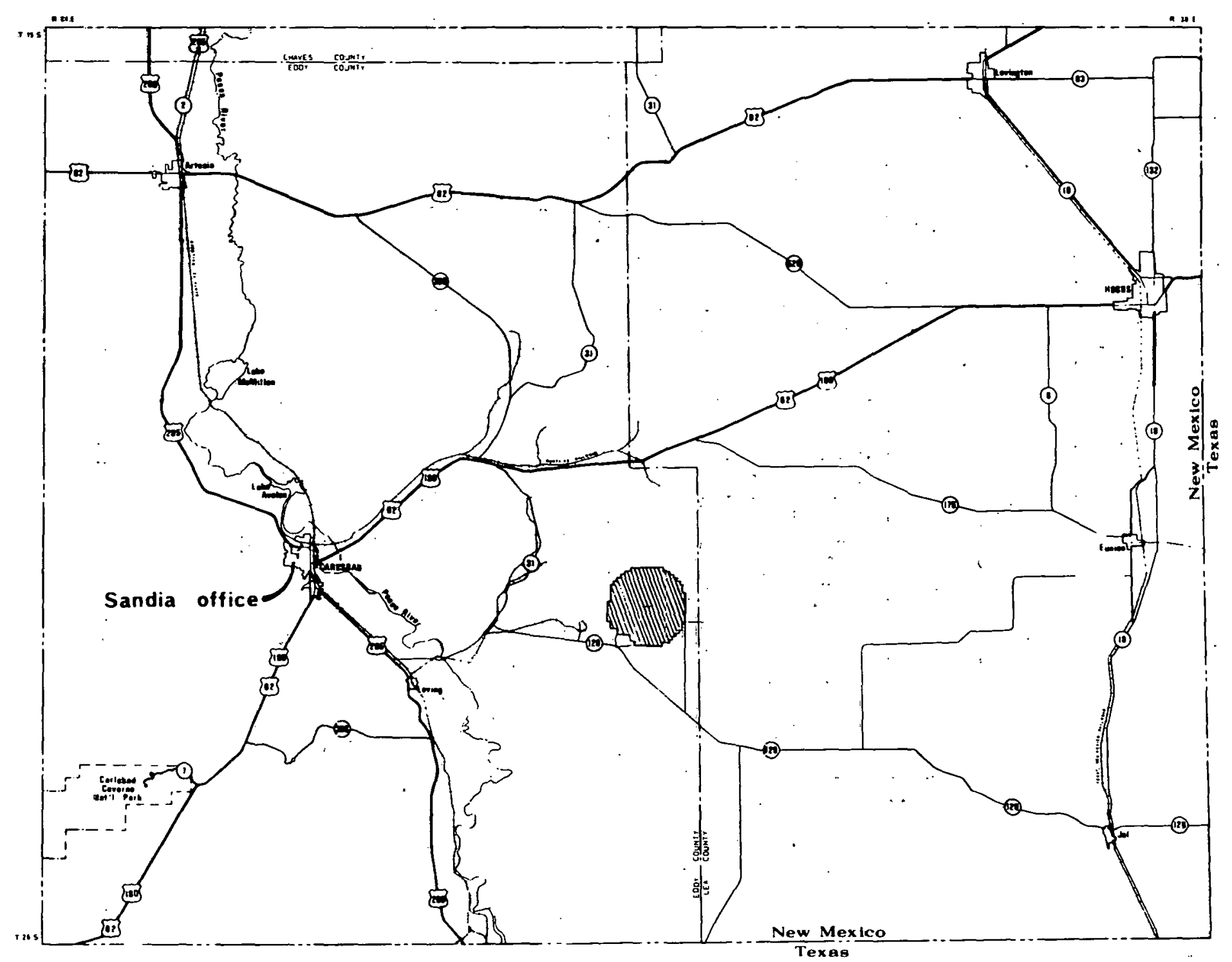

Figure 1. General Location of WIPP Land Withdrawal 


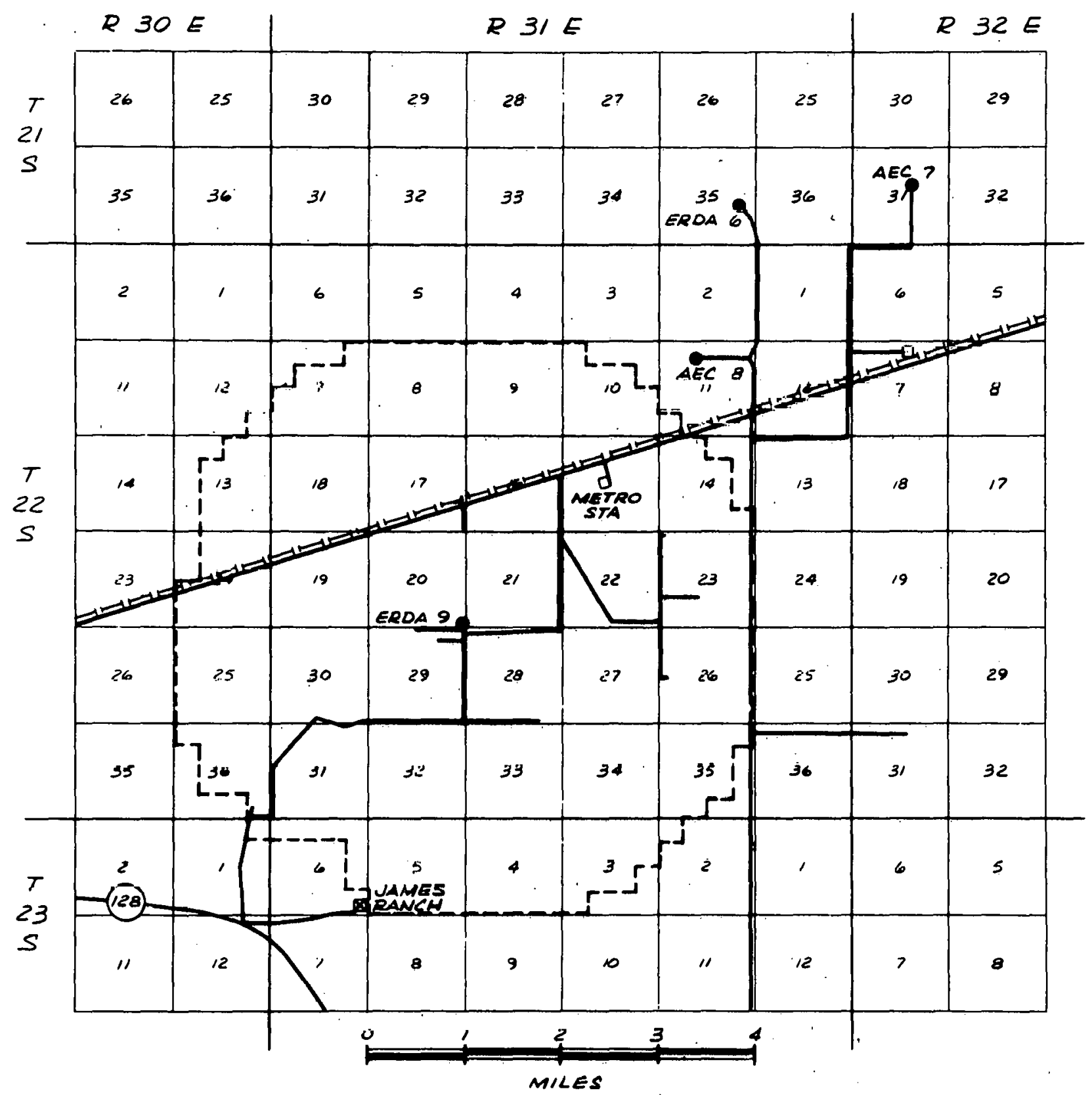

EXISTING ROADS

FE8. 77

Figure 2. WIPP Study Area 


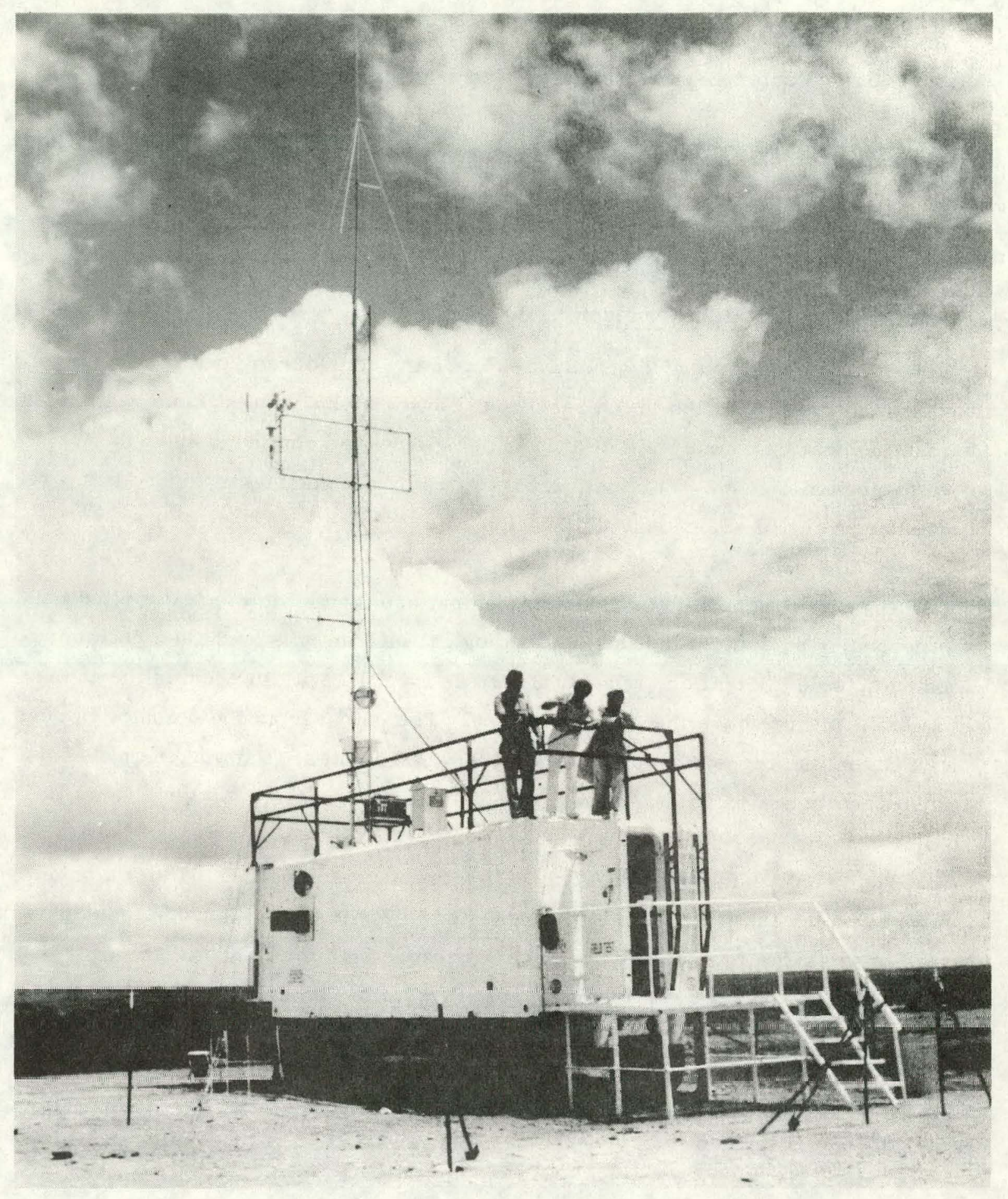

Figure 3. Present Meteorological Station at WIPP Site 


\section{RADIATION-MONITORING PROGRAM}

Direct radiation measurements are being made at the WIPP meteorological station with a Reuter-Stokes pressurized ionization chamber. Also, a limited number of thermoluminescent dosimeters have been fielded in the area. Sampling to determine average gross beta concentrations in air has been initiated. Summaries of the analytical procedures and the data collected are presented in the following sections.

\section{Reuter-Stokes Ionization Chamber}

Natural radiation background rates can vary considerably with time. In order to document this variation in the background in the study area, a Reuter-Stokes pressurized ionization chamber (RSS-111) is being operated continuously at the WIPP meteorological station. This unit is calibrated by the manufacturer and has a reported accuracy of \pm 5 percent at $10 \mu \mathrm{R} / \mathrm{hr}$.

The power supply and readout equipment are located in the trailer that houses the recording equipment for the meteorological instruments. The ion chamber, located outside the trailer, is about 3 metres from it, with the centerline of the chamber 1 metre above the ground surface. The output from the detector is recorded on an Esterline Angus 2020 data logger every 20 minutes. Data taken on the hour are transferred to IBM cards for data processing and storage.

The hourly data obtained from the ion chamber during CY 1976 have been averaged on a weekly basis and are presented in Table I and Figure 4. The data obtained at the same time of day have been averaged on a monthly basis to provide an average diurnal variation of the background radiation for each muntlı. These data are presented in Figures 5-12. 
TABLE I

CY 1976 Radiation Background at WIPP Site as Meașured With a Reuter-Stokes Pressurized Ion Chamber

Exposure Period

Begin

$04 / 26$

$05 / 03$

$05 / 10$

$05 / 17$

$05 / 24$

$05 / 31$

$06 / .03$

$07 / 14$

$07 / 19$

$07 / 26$

$08 / 02$

$08 / 09$

$08 / 16$

$08 / 23$

$08 / 30$

$09 / 06$

$09 / 13$

$09 / 20$

$09 / 27$

$10 / 04$

$10 / 11$

$10 / 18$

$10 / 25$

$11 / 01$

$11 / 08$

$11 / 12$

$11 / 15$

$11 / 22$

$11 / 29$

$12 / 06$

$12 / 13$

$12 / 20$

$12 / 27$

End

$05 / 02$

$05 / 09$

$05 / 16$

$05 / 23$

$05 / 30$

$06 / 03$

$07 / 14$

$07 / 18$

$07 / 25$

$08 / 01$

$08 / 08$

$08 / 15$

$08 / 22$

$08 / 29$

$09 / 05$

$09 / 12$

$09 / 19$

$09 / 26$

$10 / 03$

$10 / 10$

$10 / 17$

$10 / 24$

$10 / 31$

$11 / 07$

$11 / 15$

$11 / 21$

$11 / 28$

$12 / 05$

$12 / 12$

$12 / 19$

$12 / 26$

$12 / 31$
$11 / 12$
Radiation Exposure $(\mu \mathrm{R} / \mathrm{hr})$

\begin{tabular}{ccc}
\hline Average & Maximum & Minimum \\
8.29 & 12.88 & 6.80 \\
8.32 & 13.83 & 6.84 \\
8.13 & 11.55 & 6.76 \\
8.08 & 11.10 & 6.61 \\
8.08 & 9.92 & 6.46 \\
7.98 & 9.46 & 6.50 \\
Off the line & & \\
7.92 & 10.56 & 5.93 \\
8.33 & 10.34 & 6.61 \\
9.21 & 14.78 & 6.84 \\
9.39 & 14.78 & 6.84 \\
10.00 & 19.68 & 7.07 \\
8.81 & 11.10 & 6.69 \\
9.05 & 16.07 & 7.07 \\
8.74 & 12.24 & 6.65 \\
8.65 & 12.08 & 6.12 \\
8.72 & 12.62 & 6.80 \\
8.58 & 13.38 & 7.11 \\
8.32 & 11.32 & 6.46 \\
7.96 & 10.07 & 6.19 \\
8.13 & 11.51 & 6.61 \\
8.11 & 10.94 & 6.69 \\
8.59 & 15.16 & 6.12 \\
8.03 & 10.41 & 6.38 \\
8.36 & 12.62 & 6.76 \\
8019 & 19 &
\end{tabular}

No data - lost power on met station 7.93

7.89

9.96

8.55

9.88

8. 75

11.25

8.83

10.94

10.75

8.64

11.89

8.80

10.60

6.00

6.12

6.51

7.37

7.41

7. 18

7.33

Yearly Average - 8.48 


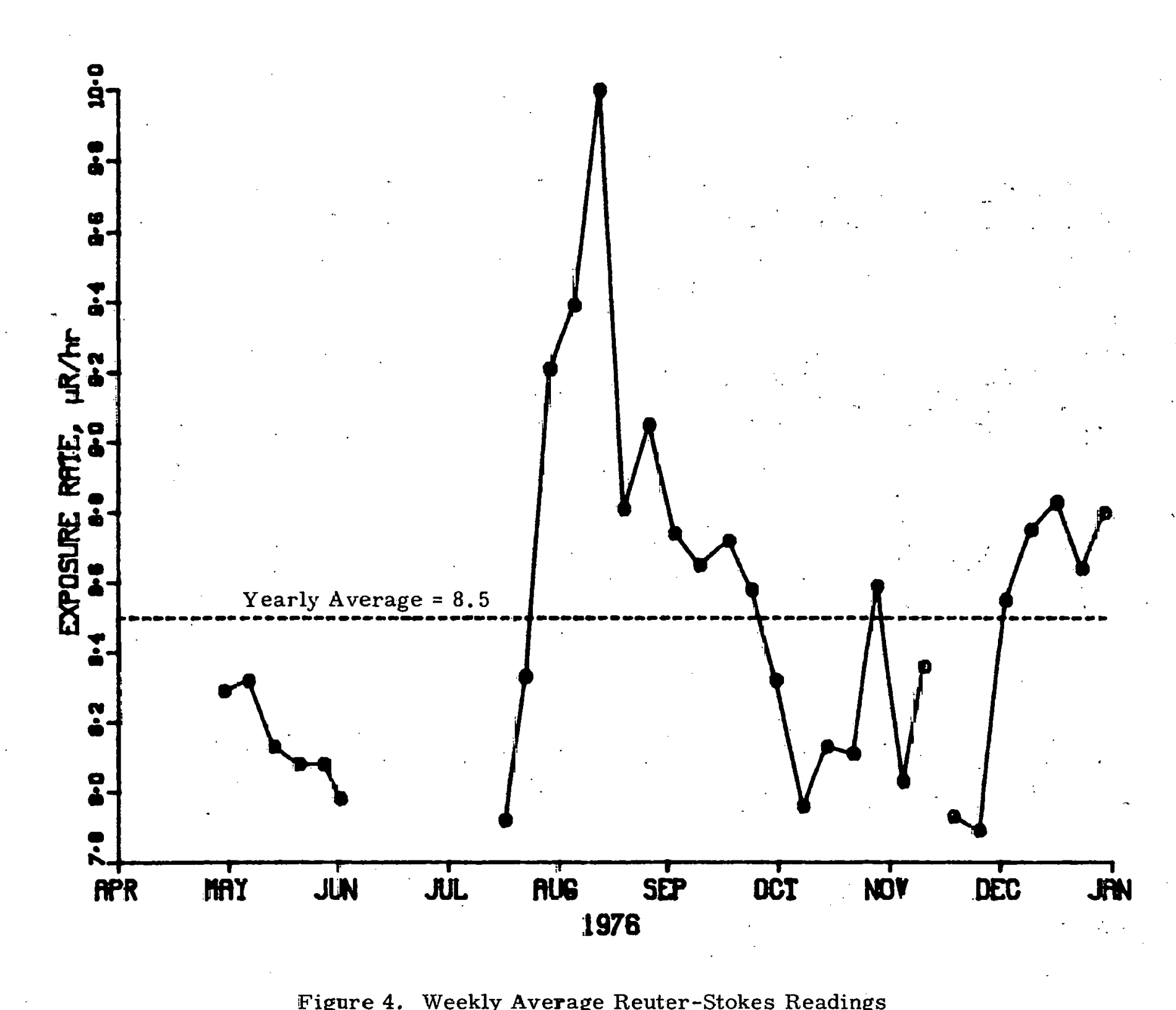




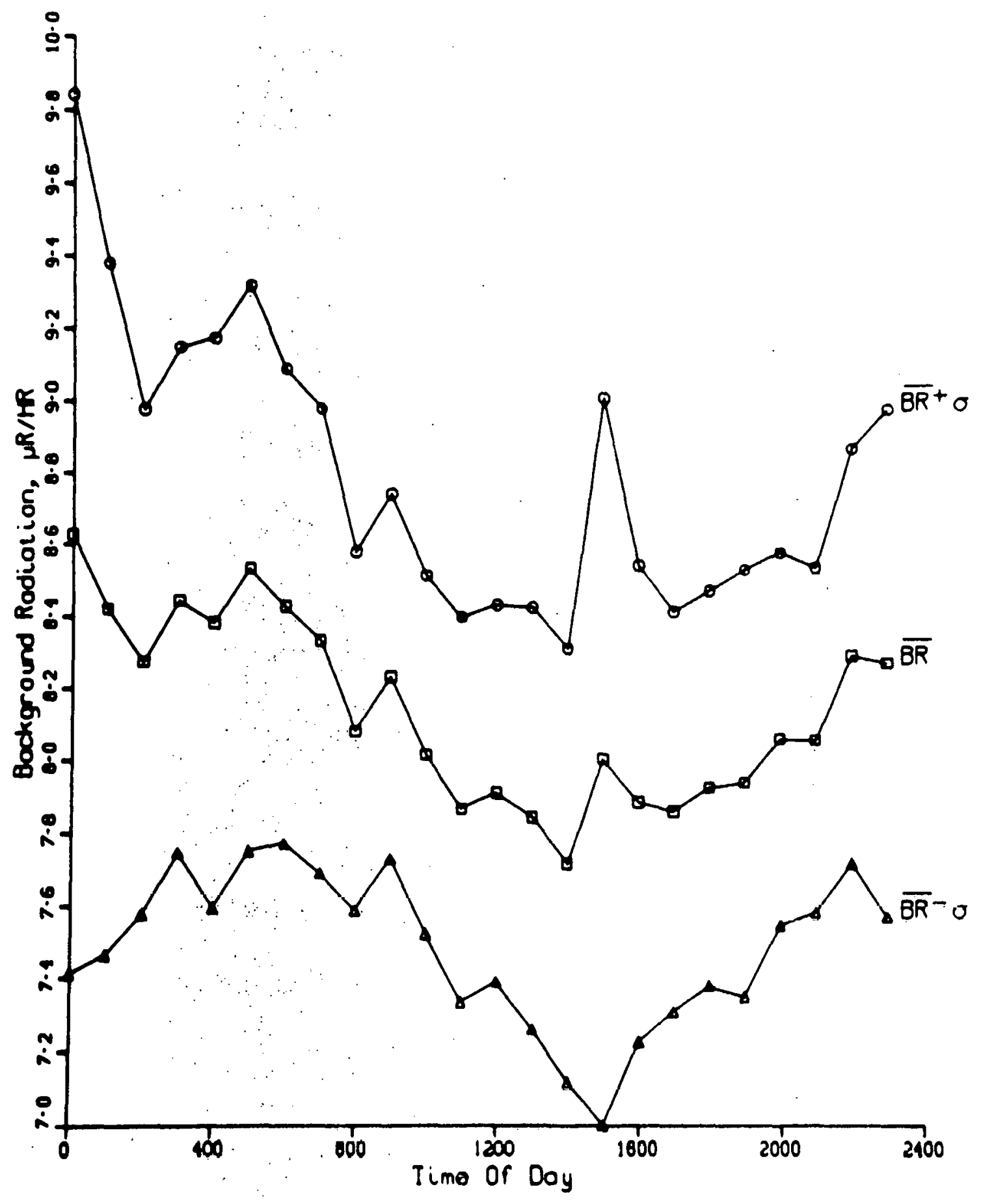

Figure 5. Diurnal Variation in Background Radiation, May 1976 


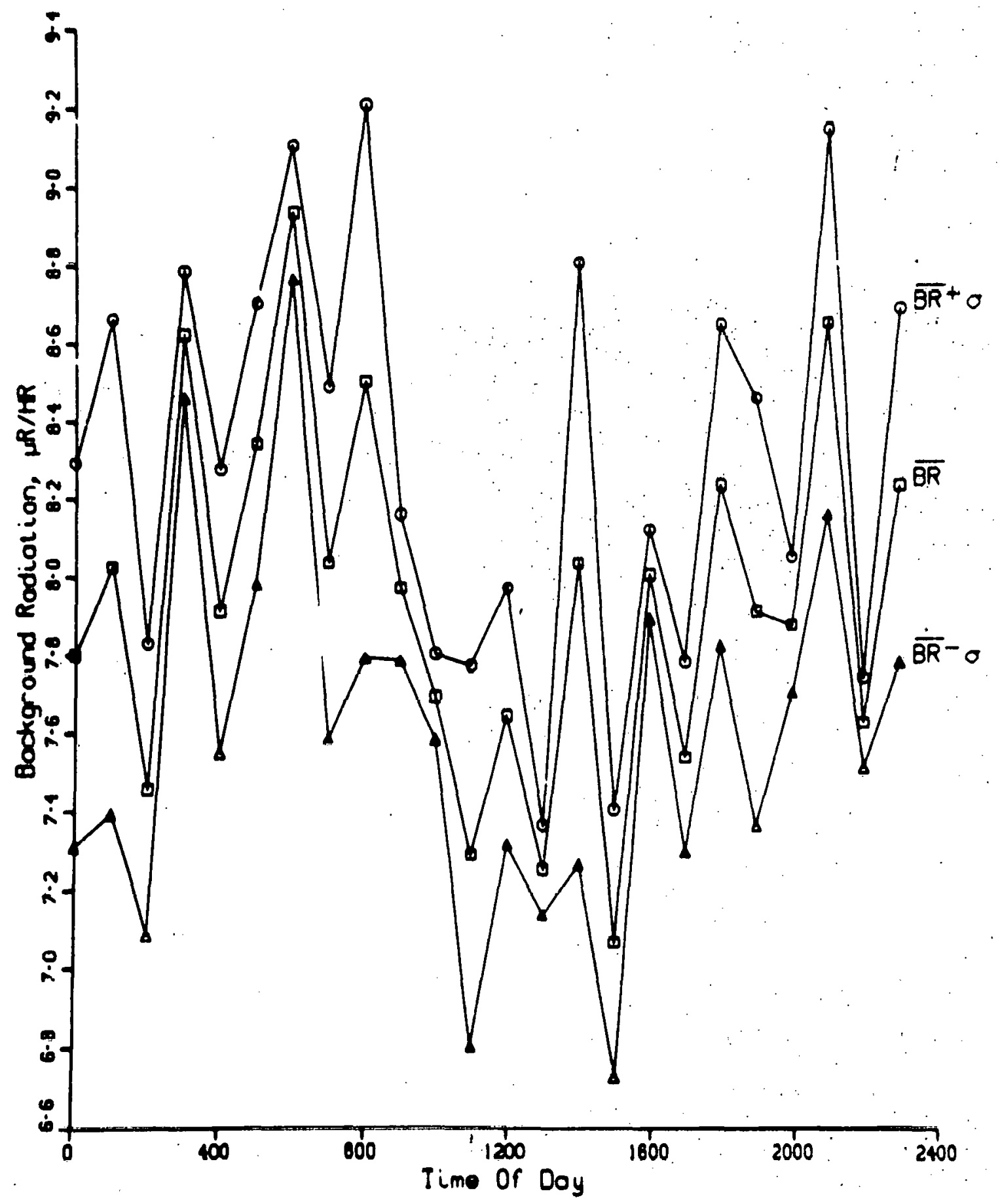

Figure 6. Diurnal Variation in Background Radiation, June 1976 


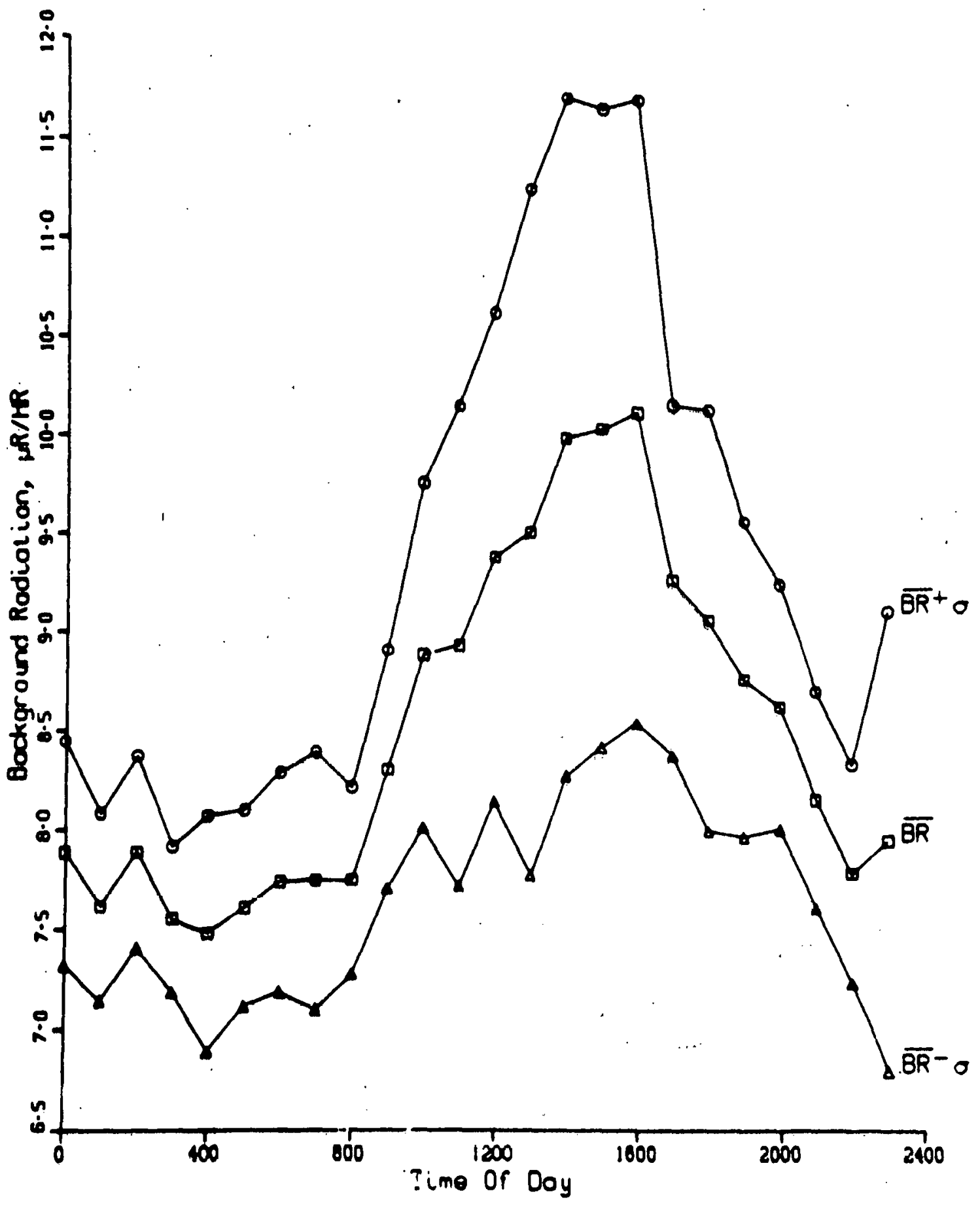

Figure 7. Diurnal Variation in Background Radiation, July 1976 


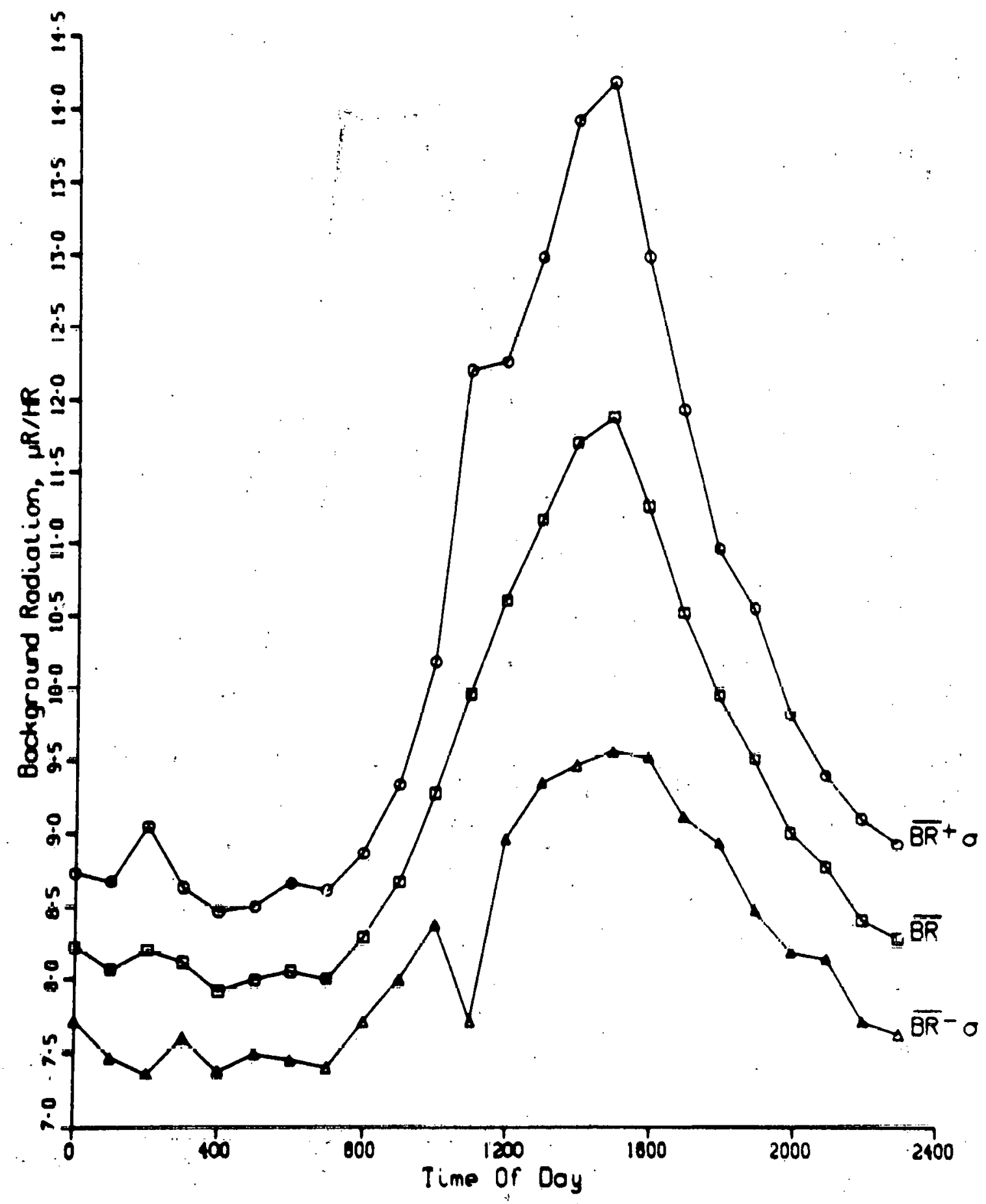

Figure 8. Diurnal Variation in Background Radiation, August 1976 


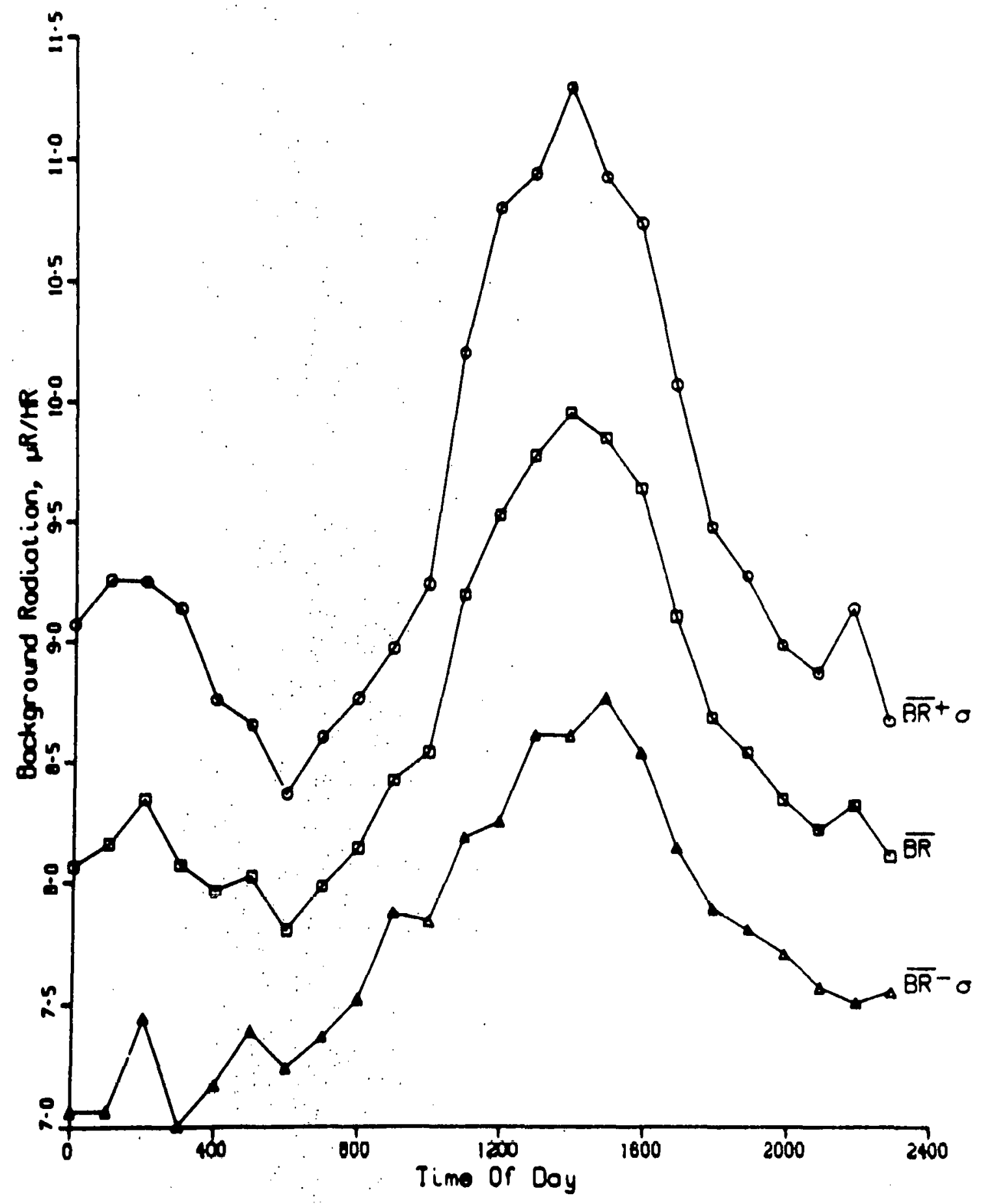

Figure 9. Diurnal Variation in Background Radiation, September 1976 


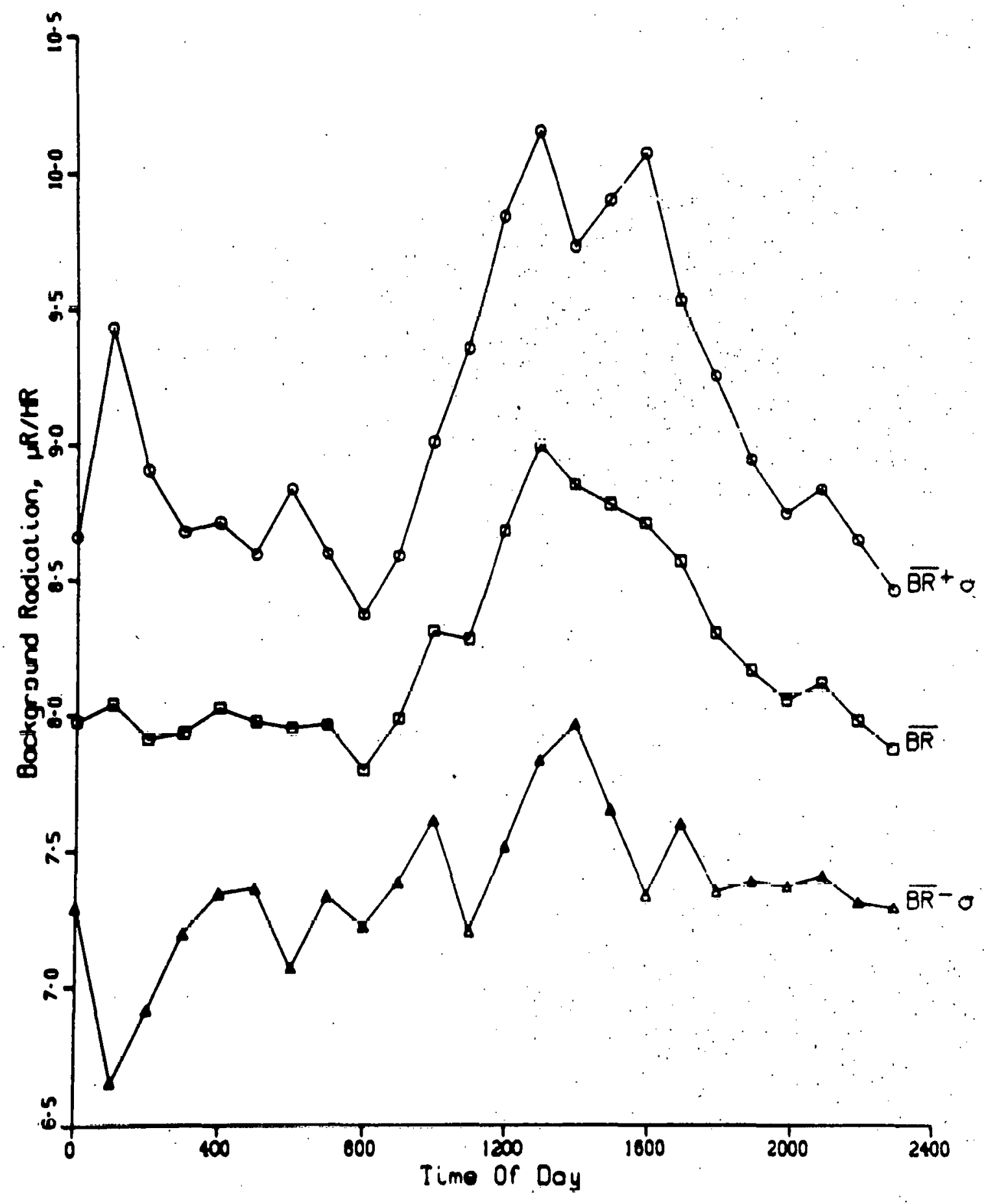

Figure 10. Diurnal Variation in Background Radiation, October 1976 


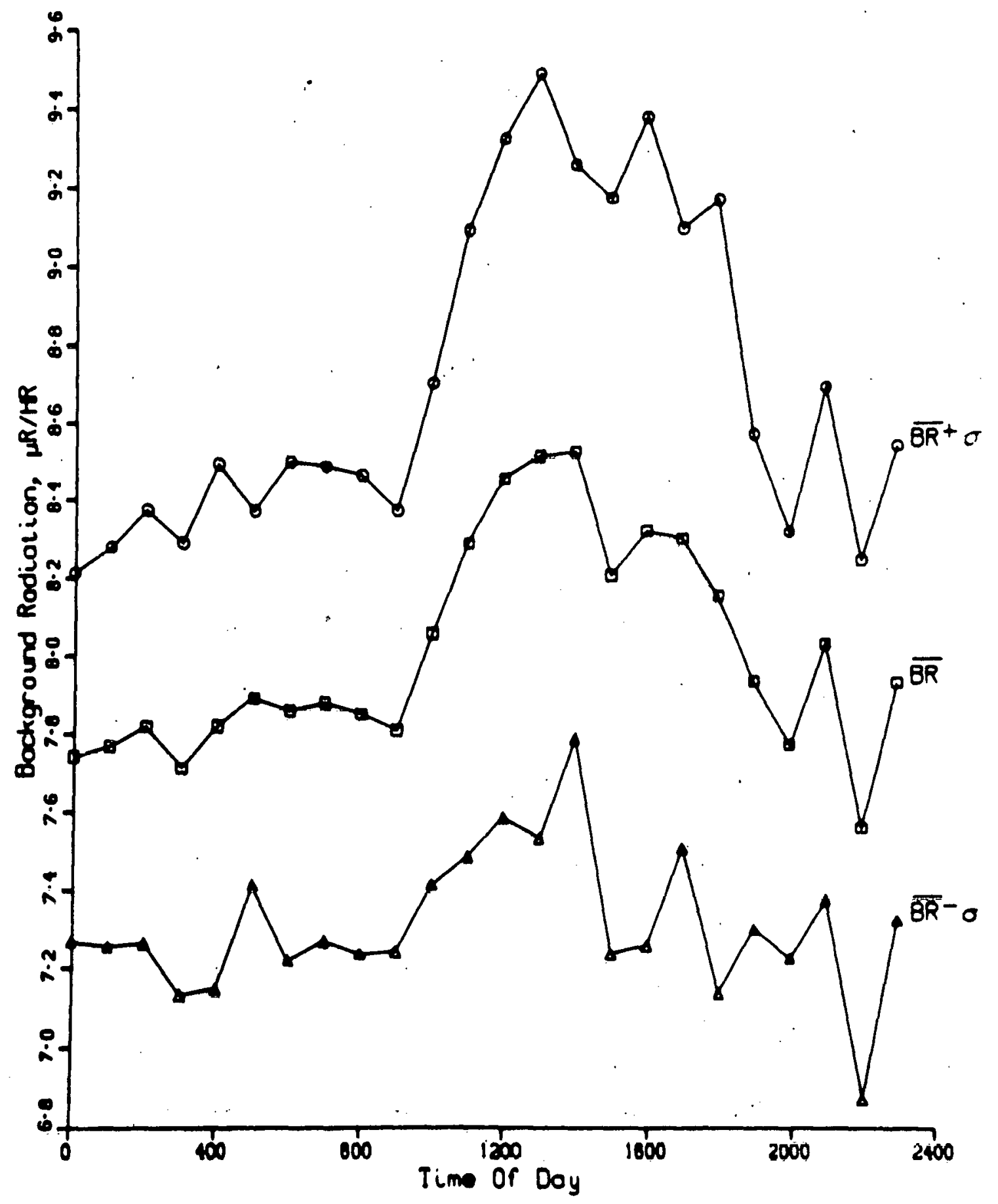

Figure 11. Diurnal Variation in Background Radiation, November 1976 


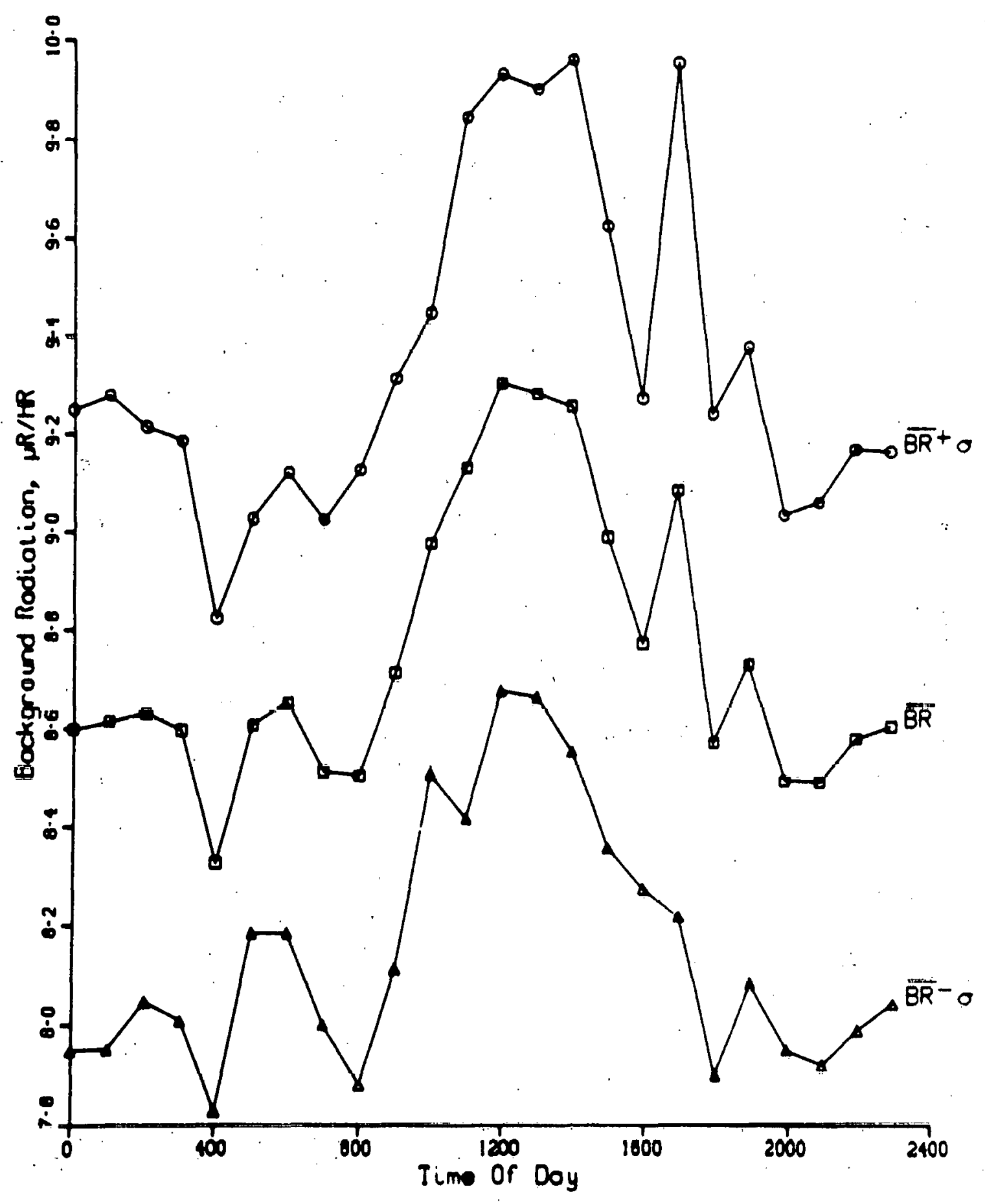

Figure 12. Diurnal Variation in Background Radiation, December 1976 


\section{Thermoluminescent Dosimeters}

Six thermoluminescent dosimetry stations have been established in the WIPP study area to determine the uniformity of the radiation background. The locations of these stations are as follows: near the drill holes designated ERDA \#6, AEC \#7, AEC \#8, and ERDA \#9; near the meteorological station; and outside the Sandia Office located in the southwest part of the city of Carlsbad (see Figures 1 and 2).

Five LiF thermoluminescent dosimeter (TLD) chips are placed at each location and are exchanged and evaluated on a quarterly basis. The TLD-100 chips are wrapped in aluminum foil and placed inside a small plastic vial. The vial is placed inside a $50-\mathrm{cm}^{3}$ polyethylene bottle, which is then suspended inside a $1-1 / 4-$ inchdiameter, thin-walled aluminum conduit (see Figure 13). The conduit is driven vertically into the ground so that the dosimeters are approximately 1 metre above the ground surface. The holder system provides about $240-\mathrm{mg} / \mathrm{cm}^{2}$ absorption for the radiation incident on the dosimeters.

In the evaluation of the exposures measured by the dosimeters, both the background while the dosimeters are in storage and the background while they are being transported to the field location are considered. The TLDs used for calibration are exposed to an NBS-traceable cobalt-60 source midway through the field cycle. Output from the five chips in a package is averaged to obtain the reported exposure for each station. The data are presented in Table II and Figure 14. 


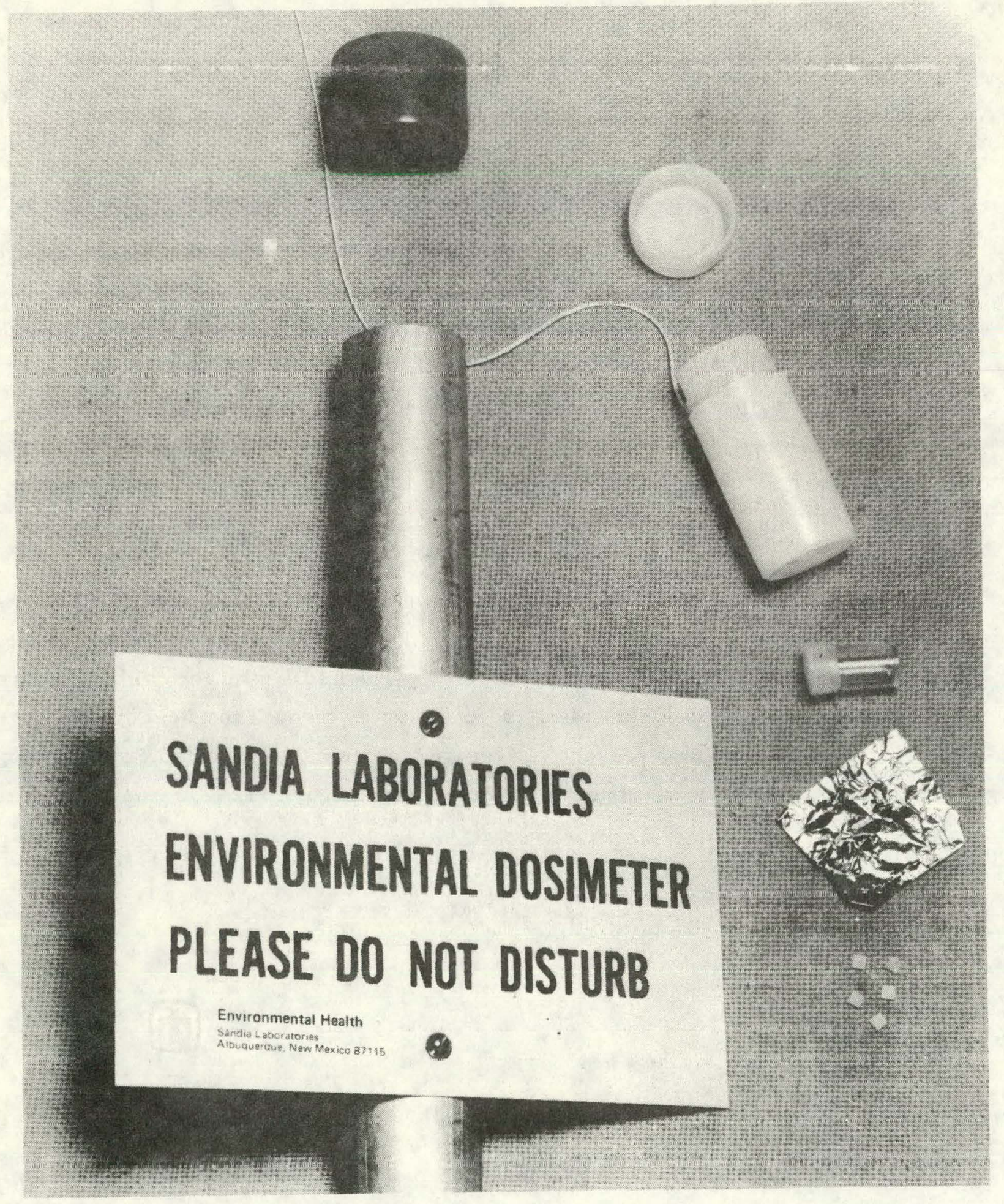

Figure 13. Sandia Laboratories Environmental Dosimeter 
TABLE II

TLD Data From WIPP Site - CY 1976

\begin{tabular}{|c|c|c|c|c|c|c|c|c|}
\hline & \multicolumn{2}{|c|}{ First Quarter } & \multicolumn{2}{|c|}{ Second Quarter } & Third Quarter & \multicolumn{2}{|c|}{ Fourth Quarter } \\
\hline & & $\begin{array}{l}1 / 13 / 76 \text { to } \\
(\mathrm{mR})\end{array}$ & $\begin{array}{l}4 / 26 / 76 \\
(\mu \mathrm{R} / \mathrm{hr}) \\
\end{array}$ & $\begin{array}{c}4 / 26 / 76 \\
(\mathrm{mR}) \\
\end{array}$ & to $\begin{array}{r}7 / 14 / 76 \\
(\mu \mathrm{R} / \mathrm{hr}) \\
\end{array}$ & $\begin{array}{cc}7 / 14 / 76 & \text { to } 10 / 13 / 76 \\
(\mathrm{mR}) & (\mu \mathrm{R} / \mathrm{hr}) \\
\end{array}$ & $\begin{array}{l}10 / 13 / 76 \\
\quad(\mathrm{mR}) \\
\end{array}$ & to $\begin{array}{r}1 / 10 / 77 \\
(\mu \mathrm{R} / \mathrm{hr})\end{array}$ \\
\hline $\begin{array}{l}\text { Sandia } \\
\text { Carlsb }\end{array}$ & $\begin{array}{l}\text { Office } \\
\text { d }\end{array}$ & $\cdots$ & -- & -- & $\because--$ & Data lost in Readout & $26.5 \pm 1.6$ & $12.4 \pm 0.76$ \\
\hline $\begin{array}{l}\text { Meteor } \\
\text { Station }\end{array}$ & ological & --- & --- & -- & --- & $"$ & $21.5 \pm 1.6$ & $10.1 \pm 0.76$ \\
\hline ERDA & 6 & $20.0 \pm 4.6$ & $8.0 \pm 1.8$ & $14.5 \pm 2.2$ & $7.6 \pm 1.1$ & $n$ & $20.0 \pm 1.5$ & $9.4 \pm 0.66$ \\
\hline A EC & 7 & $22.0 \pm 5.0$ & $8.8 \pm 2.0$ & $16.0 \pm 2.1$ & $8.4 \pm 1.1$ & $"$ & $24.5 \pm 1.6$ & $11.5 \pm 0.76$ \\
\hline AEC & 8 & $23.0 \pm 4.7$ & $9.2 \pm 1.9$ & $15.0 \pm 2.1$ & $7.9 \pm 1.1$ & $"$ & $22.5 \pm 1.6$ & $10.5 \pm 0.76$ \\
\hline ERDA & 9 & -- & --- & -- & -- & $n$ & $22.5 \pm 1.6$ & $10.5 \pm 0.76$ \\
\hline
\end{tabular}




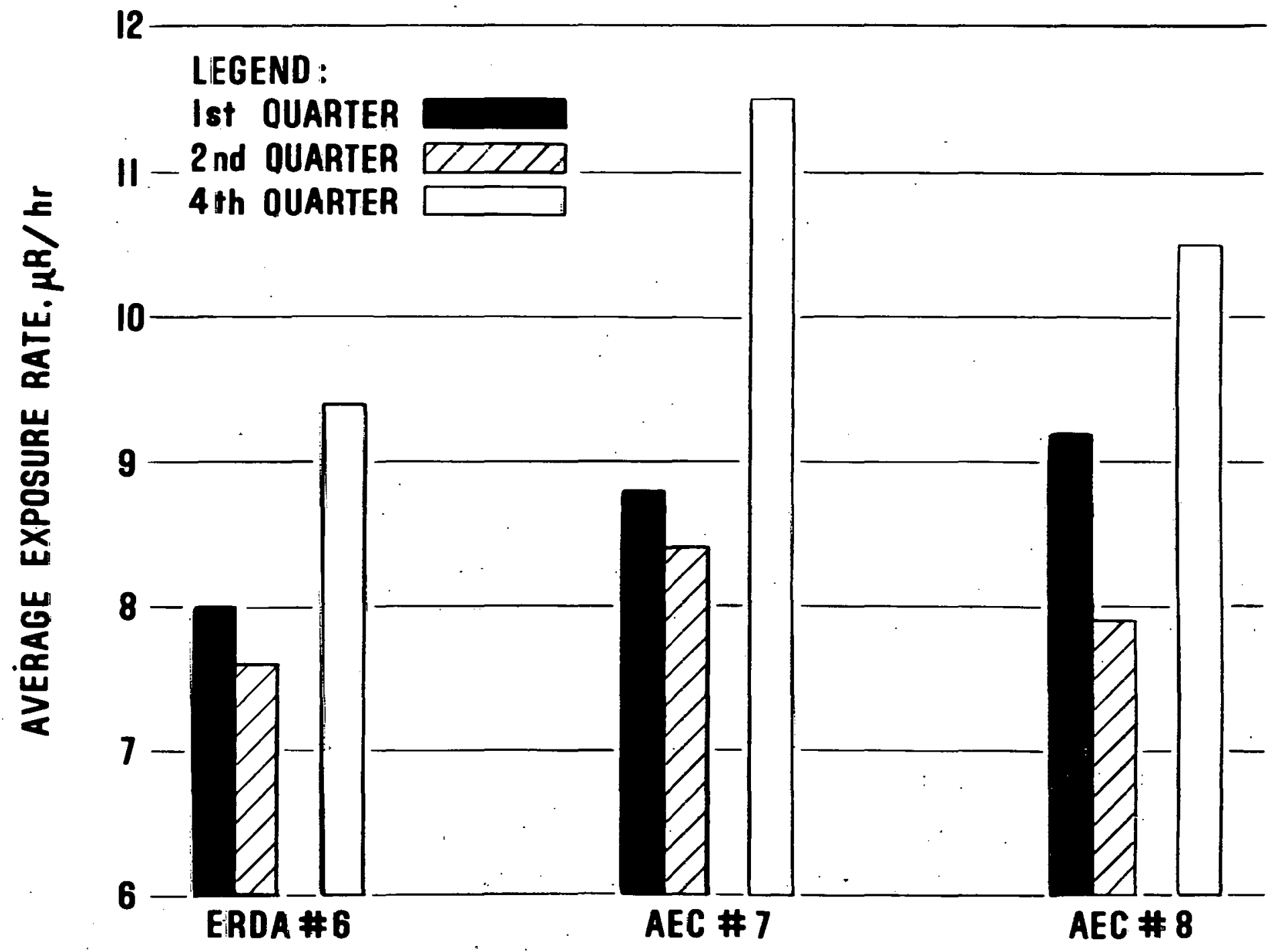

Figure 14. TLD Data-1976, WIPP Study A rea 


\section{Gross Beta Concentrations in Air}

Airborne gross beta concentrations are being determined in the WIPP study area using a high-volume air sampler. This sampler is operated on the roof of the trailer that houses the recording equipment for the meteorological measurements. The samples are taken approximately 5 metres above the ground surface.

Samples are taken 3 times each week, with each sample collected for 24 hours at a sampling rate of $18.5 \mathrm{ft}^{3} / \mathrm{min}$. Since the air samples are also used for airquality measurements, a combination of Whatman 41 and MSA Type $1106 \mathrm{BH}$ (without organic binder) fiberglass filter media have been used. The data have not been corrected for differences in estimated collection efficiency for these media.

After the air samples have been taken, the filters are held for at least 7 days before analysis to allow the radon-thoron daughters to decay. The samples are then counted with a beta proportional counter. If the sample indicates an activity greater than $0.060 \mathrm{pCi} / \mathrm{m}^{3}$, a gamma scan may also be taken. The data ortained in 1976 are summarized in Table III and in Figure 15. 
TABLE: II

Average Gross Beta Concentrations in Air at W!PP'Site - CY 1976

\begin{tabular}{|c|c|}
\hline \multicolumn{2}{|c|}{$\begin{array}{l}\text { Sampling } \\
\text { Period }\end{array}$} \\
\hline$\overline{\text { From }}$ & To \\
\hline $2 / 04$ & $2 / 05$ \\
\hline $2 / 10$ & $2 / 11$ \\
\hline $2 / 17$ & $2 / 18$ \\
\hline $2 / 19$ & $2 / 20$ \\
\hline $2 / 23$ & $2 / 24$ \\
\hline $3 / 03$ & $3 / 04$ \\
\hline $3 / 09$ & $3 / 10$ \\
\hline $3 / 11$ & $3 / 12$ \\
\hline $3 / 15$ & $3 / 16$ \\
\hline $3 / 16$ & $3 / 17$ \\
\hline $3 / 17$ & $3 / 18$ \\
\hline $3 / 23$ & $3 / 24$ \\
\hline $3 / 25$ & $3 / 26$ \\
\hline $3 / 30$ & $3 / 31$ \\
\hline $1 / 06$ & $1 / 07$ \\
\hline $4 / 12$ & $4 / 13$ \\
\hline $4 / 13$ & $4 / 14$ \\
\hline $4 / 14$ & $4 / 15$ \\
\hline $4 / 18$ & $4 / 19$ \\
\hline $4 / 19$ & $4 / 20$ \\
\hline $4 / 20$ & $4 / 21$ \\
\hline $4 / 25$ & $4 / 26$ \\
\hline $5 / 03$ & $5 / 04$ \\
\hline $5 / 04$ & $5 / 05$ \\
\hline $5 / 05$ & $5 / 06$ \\
\hline $5 / 10$ & $5 / 11$ \\
\hline $5 / 11$ & $5 / 12$ \\
\hline $5 / 12$ & $5 / 13$ \\
\hline $5 / 17$ & $5 / 18$ \\
\hline $5 / 18$ & $5 / 19$ \\
\hline $5 / 19$ & $5 / 20$ \\
\hline $5 / 24$ & $5 / 25$ \\
\hline $5 / 20$ & $5 / 25$ \\
\hline $5 / 26$ & $5 / 27$ \\
\hline $6 / 01$ & $6 / 02$ \\
\hline $6 / 02$ & $6 / 0.3$ \\
\hline $6 / 03$ & $6 / 04$ \\
\hline $6 / 14$ & $6 / 15$ \\
\hline $6 / 15$ & $6 / 16$ \\
\hline $6 / 16$ & $6 / 17$ \\
\hline $6 / 21$ & $6 / 22$ \\
\hline $6 / 22$ & $6 / 23$ \\
\hline $6 / 23$ & $6 / 24$ \\
\hline $6 / 28$ & $6 / 30$ \\
\hline $6 / 30$ & $7 / 01$ \\
\hline $7 / 01$ & $7 / 02$ \\
\hline $7 / 06$ & $7 / 07$ \\
\hline $7 / 07$ & $7 / 08$ \\
\hline $7 / 08$ & $7 / 09$ \\
\hline $7 / 12$ & $7 / 13$ \\
\hline $7 / 13$ & $7 / 14$ \\
\hline $7 / 14$ & $7 / 15$ \\
\hline $7 / 19$ & $7 / 20$ \\
\hline $7 / 20$ & $7 / 21$ \\
\hline $7 / 21$ & $7 / 22$ \\
\hline $7 / 26$ & $7 / 27$ \\
\hline $7 / 27$ & $7 / 28$ \\
\hline $7 / 28$ & $7 / 29$ \\
\hline $8 / 03$ & $8 / 04$ \\
\hline $8 / 04$ & $8 / 05$ \\
\hline
\end{tabular}

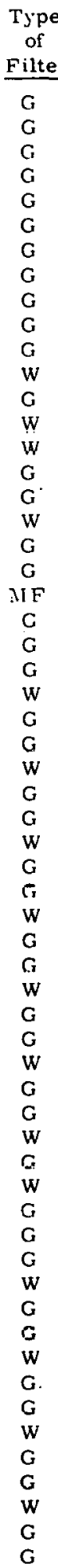

\begin{tabular}{|c|c|c|}
\hline \multirow{2}{*}{$\begin{array}{l}\text { Mlonthly } \\
\text { Average } \\
\left.\text { (pCi } / \mathrm{m}^{3}\right)\end{array}$} & \multicolumn{2}{|c|}{$\begin{array}{l}\text { Sampling } \\
\text { Period }\end{array}$} \\
\hline & From & To \\
\hline & $: 8 / 05$ & $8 / 06$ \\
\hline & $8 / 09$ & $8 / 10$ \\
\hline & $8 / 10$ & $8 / 11$ \\
\hline & $8 / 11$ & $8 / 12$ \\
\hline \multirow[t]{9}{*}{$0.016 \pm 0.003$} & $8 / 16$ & $8 / 17$ \\
\hline & $8 / 18$ & $8 / 19$ \\
\hline & $8 / 19$ & $8 / 20$ \\
\hline & $8 / 23$ & $8 / 24$ \\
\hline & $8 / 24$ & $8 / 25$ \\
\hline & $8 / 25$ & $8 / 26$ \\
\hline & $8 / 30$ & $8 / 31$ \\
\hline & $8 / 31$ & $y / 01$ \\
\hline & $9 / 02$ & $9 / 04$ \\
\hline \multirow[t]{8}{*}{$0.024 \pm 0.003$} & $9 / 07$ & $9 / 08$ \\
\hline & 9108 & 9109 \\
\hline & $9 / 09$ & $9 / 10$ \\
\hline & $9 / 14$ & $9 / 15$ \\
\hline & $9 / 15$ & $9 / 16$ \\
\hline & $9 / 16$ & $9 / 17$ \\
\hline & $9 / 20$ & $9 / 21$ \\
\hline & $9 / 21$ & $9 / 22$ \\
\hline \multirow[t]{12}{*}{$0.019 \pm 0.003$} & $9 / 22$ & $9 / 27$ \\
\hline & $9 / 28$ & $y / 2 y$ \\
\hline & $9 / 29$ & $9 / 30$ \\
\hline & $9 / 30$ & $10 / 01$ \\
\hline & $10 / 04$ & $10 / 05$ \\
\hline & $10 / 06$ & $10 / 07$ \\
\hline & $10 / 13$ & $10 / 14$ \\
\hline & $10 / 14$ & $10 / 15$ \\
\hline & $10 / 20$ & $10 / 21$ \\
\hline & $10 / 21$ & $10 / 22$ \\
\hline & $10 / 25$ & $10 / 26$ \\
\hline & $10 / 36$ & $10 / 37$ \\
\hline \multirow[t]{11}{*}{$0.020 \pm 0.003$} & $10 / 27$ & $10 / 28$ \\
\hline & $11 / 01$ & $11 / 02$ \\
\hline & $11 / 02$ & $11 / 03$ \\
\hline & $11 / 03$ & 1104 \\
\hline & $11 / 08$ & $11 / 09$ \\
\hline & $11 / 09$ & $11 / 10$ \\
\hline & $11 / 10$ & $11 / 11$ \\
\hline & $11 / 15$ & $11 / 16$ \\
\hline & $11 / 16$ & $11 / 17$ \\
\hline & $11 / 17$ & $11 / 18$ \\
\hline & $11 / 18$ & $11 / 19$ \\
\hline \multirow[t]{13}{*}{$0.017 \pm 0.003$} & $11 / 19$ & $11 / 20$ \\
\hline & $11 / 20$ & $11 / 21$ \\
\hline & $11 / 21$ & $11 / 22$ \\
\hline & $11 / 22$ & $11 / 23$ \\
\hline & $11 / 23$ & $11 / 24$ \\
\hline & $11 / 24$ & $11 / 28$ \\
\hline & $11 / 20$ & $11 / 30$ \\
\hline & $11 / 30$ & $12 / 01$ \\
\hline & $12 / 01$ & $12 / 02$ \\
\hline & $12 / 06$ & $12 / 07$ \\
\hline & $12 / 07$ & $12 / 08$ \\
\hline & $12 / 08$ & $12 / 09$ \\
\hline & $12 / 13$ & $12 / 14$ \\
\hline \multirow[t]{2}{*}{$0.012 \pm 0.003$} & $12 / 14$ & $12 / 15$ \\
\hline & $12 / 15$ & $12 / 16$ \\
\hline
\end{tabular}

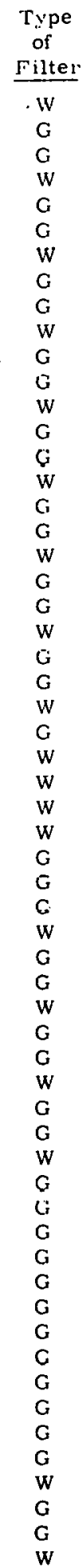

Gross 13eta $-\left(\mathrm{pCi} / \mathrm{m}^{3}\right)$

$0.020 \pm 0.003$ $0.026 \pm 0.004$ $0.026 \pm 0.004$ $0.022 \pm 0.003$ $0.008 \pm 0.003$ $0.008 \pm 0.003$ $0.017 \pm 0.003$ $0.030 \pm 0.004$ $0.030 \pm 0.004$ $0.016 \pm 0.003$ $0.012 \pm 0.003$ $0.018 \pm 0.003$ $0.016 \pm 0.002$ $0.010 \pm 0.003$ U. $006 \pm 0.003$ $0.013 \pm 0.003$ $0.014 \pm 0.003$ $0.014 \pm 0.003$ $0.010 \pm 0.002$ $0.023 \pm 0.003$ $0.035 \pm 0.004$ $0.021 \pm 0.001$ 0. $010 \pm 0.003$ $0.029 \pm 0.004$ $0.023 \pm 0.003$ $0.095 \pm 0.005$ 0. $247 \pm 0.008$ $0.119 \pm 0.006$ $0.100 \pm 0.005$ $0.674 \pm 0.013$ 1. $069 \pm 0.016^{\mathrm{a}}$ $1.044=0.018$ ก. $474 \pm 0.011$ $0.021 \pm 0.003$ $0.642 \pm 0.012$ $0.565 \pm 0.011$ $0.348 \pm 0.009$ 0. $354 \pm 0.009$ $0.306 \pm 0.009$ 0. $210 \pm 0.007$ $0.050 \pm 0.004$ 0. $152 \pm 0.006$ $0.168 \pm 0.006$ $0,179 \pm 0.007$

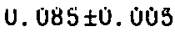
$0.136 \pm 0.006$ $0.159 \pm 0.006$ $0.176 \pm 0.007$ $0.157 \pm 0.006$ $0.091 \pm 0.002$ $0.303 \pm 0.007$ $0.085 \pm 0.005$ $0.046 \pm 0.004$ $0.086 \pm 0.005$ $0.072 \pm 0.005$ $0.076 \pm 0.004$ $0.087 \pm 0.005$ $0.084 \pm 0.005$ $0.072 \pm 0.004 \quad 0.075 \pm 0.005$
Nonthly

Average $\left(\mathrm{pCi} / \mathrm{m}^{3}\right)$

$0.019 \pm 0.003$ $0.017+0.003$

$0.427 \pm 0.009$

\section{$0.226 \pm 0.007$}

Type of Filter: $\quad G$ - MSA Type 1106BH (without organic binder) fiberglass W - Wiatman 41 MF - Millipore, Type HA

\footnotetext{
${ }^{a}$ Pump quit during run - concentration actually higher than shown.
} 


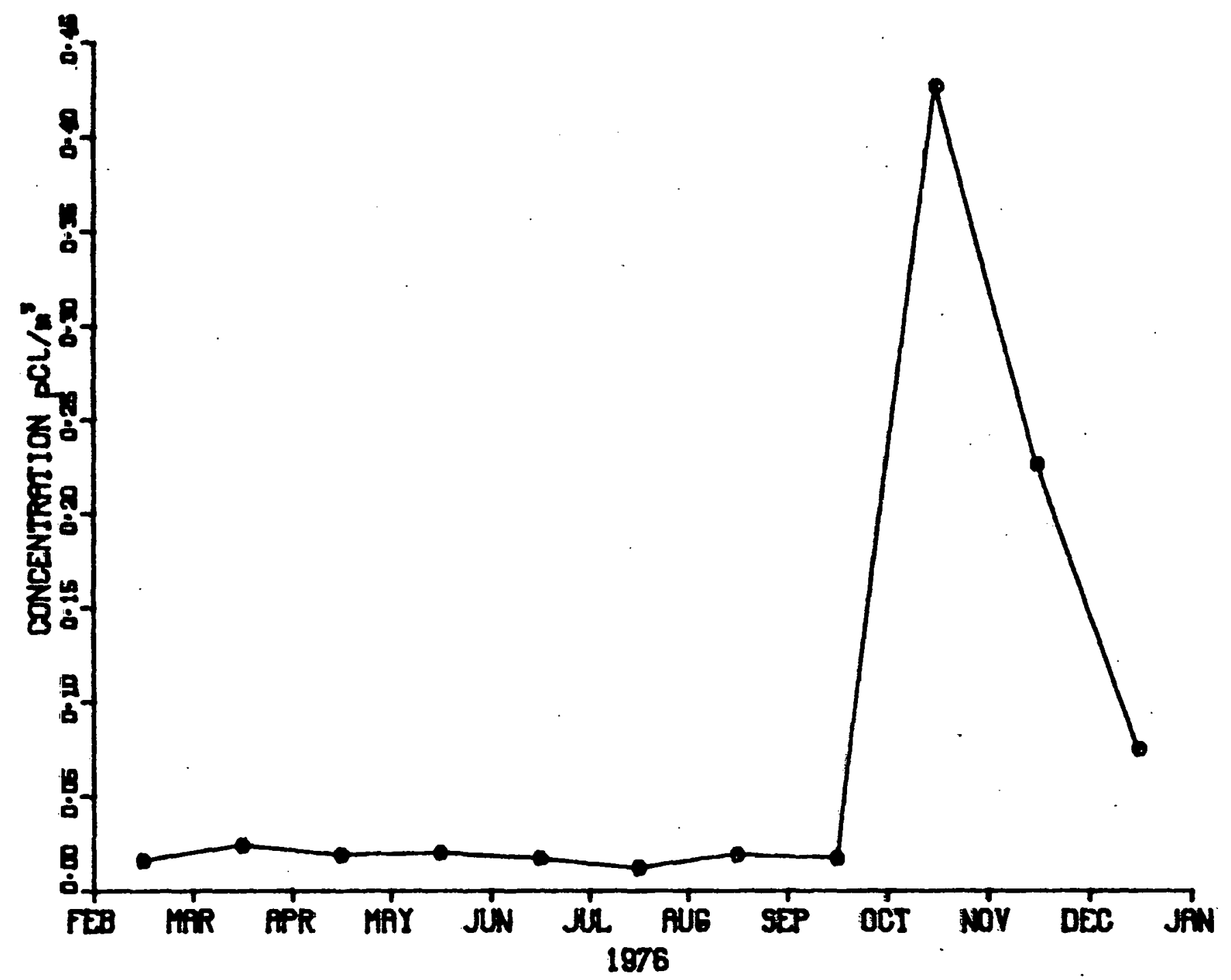

Figure 15. Average Gross Beta Activity in Air 


\section{ASSESSMENT OF DOSE TO PUBLIC}

The major components of the background radiation environment of any location are cosmic rays, terrestrial radiation sources such as potassium-40 and the decay products of the uranium and thorium series in the earth's crust, and global fallout from nuclear weapons testing in the atmosphere. Each of these components contributes to the background exposure rate being measured at the WIPP site, and each is discussed individually.

Cosmic radiation varies with latitude and altitude, with the latter being the significant factor. 'The intensity of cosmic radiation increases from equatorial to polar latitudes. and also increases with increasing altitudes. Within the United States the latitude effect may be neglected for all practical purposes. ${ }^{1}$ At the altitude of the WIPP site $(1.06 \mathrm{~km})$, the absorbed dose rate in air due to cosmic radiatior: is estimated to be $37 \mathrm{mrad} / \mathrm{yr}^{2-4}$

The principal radioactive elements that contribute to the radiation emanating frorn the surface of the ground are potassium-40, members of the uranium series, and members of the thorium series. This terrestrial gamma background is not uniform over the surface of the earth, but rather depends on the soil concentration of the naturally occurring radionuclides in the region of interest.

The estimated average absorbed dose rate in air from terrestrial sources for the United States is $44 \mathrm{mrad} / \mathrm{yr}^{2}{ }^{2}$ Evaluation of aerial radiological monitoring system (ARMS) data taken in the Carlsbad area implies that this area may have a somewhat lower dose rate than the average value for the United States. Based or the A RMS data, an estimate of $26 \mathrm{mrad} / \mathrm{yr}^{2,5}$ has been made for the terrestrial component of the radiation background in the WIPP area.

The content of uranium, thorium, and potassium in the soil and rocks of any specific geographical region is essentially constant; however, the dose rate in air depends upon a number of factors. Variations are related to such meteorological conditions as atmospheric stability, rainfall, moisture in the soil, temperature, barometric pressure, and relative humidity - all of which affect the concentration of radon and thoron and their daughter products in the surface layer of the atmosphere. Determination of the exposure rate from this source therefore requires 
the determination of the process that most significantly affects the radon and thoron concentration in the surface air layer at a given moment.

The absorbed dose rate in air due to radon and thoron and their associated daughter products ranges from $0.4 \mathrm{mrad} / \mathrm{yr}$ for conditions in which strong mixing occurs, to $11 \mathrm{mrad} / \mathrm{yr}$ for strong inversion conditions. An average value for the absorbed dose rate in air from this source is $1.7 \mathrm{mrad} / \mathrm{yr}^{2}$

The other major component of the background radiation environment is global fallout. Average external gamma radiation doses in the United States due to fallout is estimated to be $1 \mathrm{mrad} / \mathrm{yr}^{6}$

Based on the information given above, the estimated annual whole-body exposure to members of the public in the vicinity of the WIPP site is $66-84 \mathrm{mrad} / \mathrm{yr}$ (7.5-9.6 $\mu \mathrm{rad} / \mathrm{hr}$ ) from external sources. This estimate does not include internally deposited radionuclides, such as potassium-40, which would add another $20 \mathrm{mrad} / \mathrm{yr}$ to the estimated exposures. 


\section{EVALUATION}

The high-pressure ionization chamber and the thermoluminescent dosimeters used in this study are calibrated with cobalt-60; therefore, all data given are expressed in terms of exposure rate, usually in microroentgens per holi: $(1 \mu \mathrm{R} / \mathrm{hr}=8.77 \mathrm{mR} / \mathrm{yr})$. Data from the literature have been expressed in terms of absorbed dose rates in soft tissue, with $\mu \mathrm{rad} / \mathrm{hr}$ being the basic measurement unit. In order to compare the measured exposure rates with the values cited, a conversion factor of $1 \mathrm{R}$ being equivalent to $0.95 \mathrm{rad}$ should be applied.

The average exposiure rate in 1.976, as measured in the WIPP area with the Reuter-Stokes pressurized ionization chamber, was $8.5 \mu \mathrm{R} / \mathrm{hr}(74 \mathrm{mR} / \mathrm{yr})$, with a maximum of $20 \mu \mathrm{R} / \mathrm{hr}$ and a minimum of $6 \mu \mathrm{R} / \mathrm{hr}$. The fluctuations between these two extremes appear to be related to the concentrations of radon and thoron (with their associated daughter products) in the near-ground air. These fluctuations in turn are dependent upon meteorological conditions, with a different parameter assuming importance at any one time.

Atmospheric stability is one of the more important parameters, ${ }^{2}$ with the radon-thoron concentrations in the near-ground air increasing as the atmosphere becomes more stable. As the atmosphere typically becomes more stable during the night (inversion conditions), an increase is noted in radon concentration, with a resultant increase in the exposure rate measured at one metre above the ground surface.

When the inversion vanishes and turbulent diffusion moves the radon into a larger volume, effectively diluting the radon-rich, near-surface air with air having a lower concentration of radon, the exposiure rate decreases. This diurnal variation of the radiation background with atmospheric blability as the important variablc can be noted in the average "diurnal" radiation background for the month of May (Figure 5).

Another important meteorological parameter is the amount of precipitation. In the atmosphere, natural radioactive particulates (primarily daughters of radon) attach themselves to dust particles, which may then become "condensation centers" for moisture in the air. If these droplets become large enough to fall to the ground 
as precipitation, the exposure rate above the surface of the ground will increase as a result of the accumulation of radon daughters (the "rainout" phenomenon).

Another phenomenon associated with precipitation is the buildup of radon and thoron and their daughters in the surface layers of the soil. As the pores of the soil become saturated with water, the migration to the atmosphere of the radon and thoron in the soil gas is decreased, thereby increasing the concentration of these radioactive species in the soil and causing a resultant increase in the exposure rate above the soil surface. If precipitation is heavy, the additional shielding offered by the water in the soil may result in some decrease in radiation levels at the surface.

As Figure 7 shows (diurnal variation in background radiation - July 1976), heating of the surface of the ground also contributes to an increase in exposure rate above the surface. As the soil gas in the surface layers of the ground is heated, it tends to rise, causing a resultant drop in the local pressure of the soil gas and increasing the escape of radon to the atmosphere. These micro-oscillations of the barometric pressure effectively "pump" the radon out of the ground, thereby increasing the radon content of the atmosphere. If this "pumping" effect occurs in conjunction with little or no wind so that there is very little vertical diffusion of the radon, very high ground-level concentrations can be attained. This could be the reason for the high exposure rate measured the afternoon of August $14(20 \mu \mathrm{R} / \mathrm{hr})$.

The data obtained through the use of TLDs agree favorably with the ReuterStokes data. Both sets of data indicate average exposure rates of $8-9 \mu \mathrm{R} / \mathrm{hr}$ in the WIPP study area. Minor variations in the exposure rate from station to station are reflected (see Table II), but not enough data have been accumulated to determine whether these variations are statistically significant. Based on one set of data, the exposure rate indicated by the station located in the city of Carlsbad is 20 percent higher than the stations in the WIPP study area. Again, not enough data have been accumulated to determine whether this difference is significant.

The TLD data obtained in the fourth quarter show an increase of 20-25 percent over data obtained in the previous quarters, all stations indicating approximately the same magnitude of increase. This increase has been attributed to the presence of global fallout from the Chinese nuclear tests (conducted September 26, 1976, and 
November 17, 1976), which air-sampling data indicated was present in the area almost all of the fourth quarter. If data from the next quarter return to the pretest levels, this conclusion may be justified.

The air-sampling data indicate that gross beta concentrations in air at the WIPP site are typically $0.02 \mathrm{pCi} / \mathrm{m}^{3}$. Although the data have not been corrected for differences in filter media, this oversight should introduce only a 2-percent error in the concentrations calculated (efficiencies for Whatman 41 and MSA Type $1106 \mathrm{BH}$ are 98 percent and 99.978 percent, respectively). ${ }^{7}$

First indications of fallout from the Chinese nuclear test conducted on September 26 were obtained from the sample taken October 4-5. Gamma spectra of the filter media confirmed the presence of short-lived fission products (Figures 16 and 17). The presence of this fission product activity caused the gross beta concentrations in air to increase to a maximum of $1.07 \mathrm{pCi} / \mathrm{m}^{3}$ (October 21-22), gradually decreasing throughout the rest of the calendar year. No clear indication of the second test, conducted on November.17, was received. Gross beta concentrations in air at the end of the year were still approximately 3 times higher than those obtained before the abovementioned atmospheric tests. 


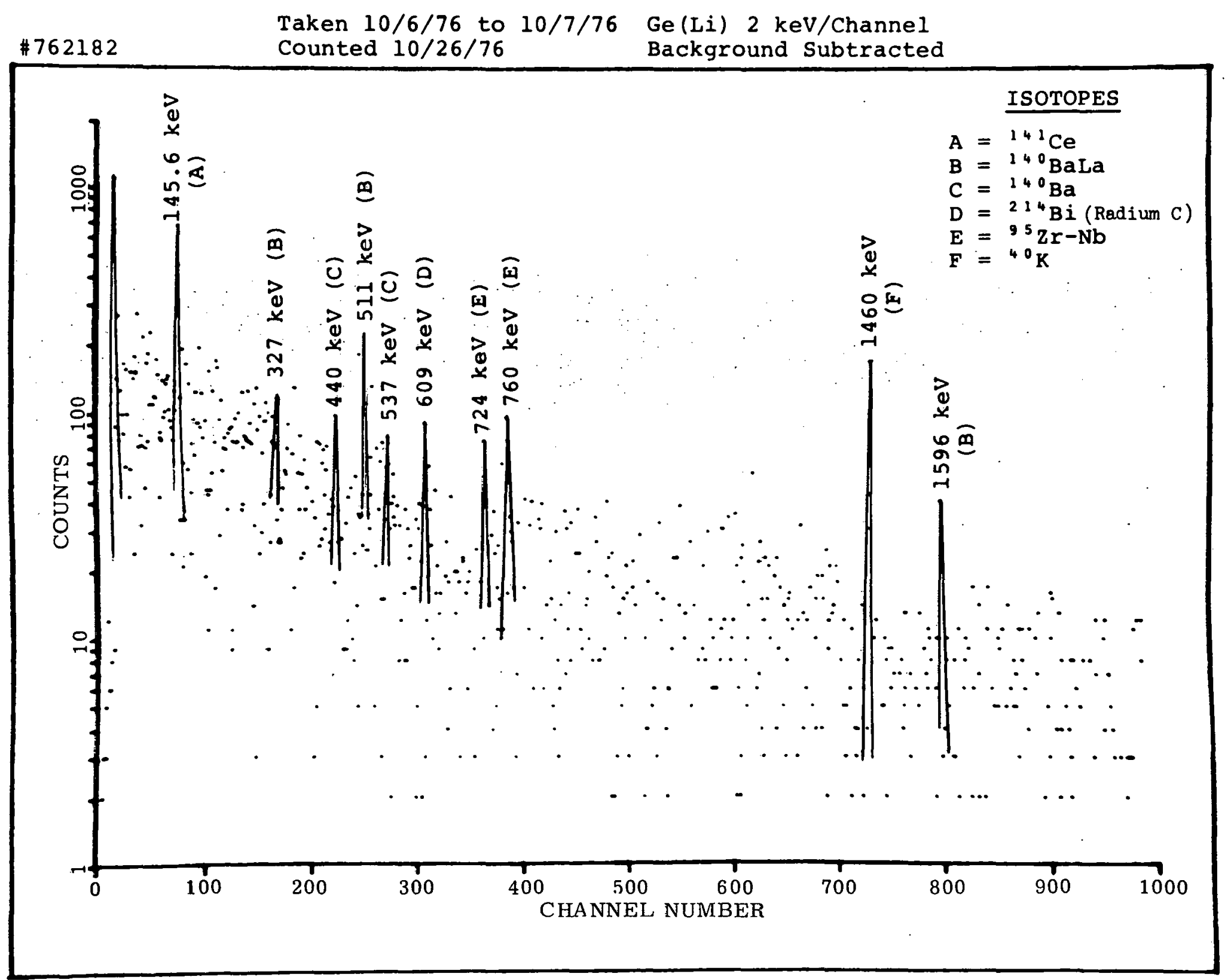




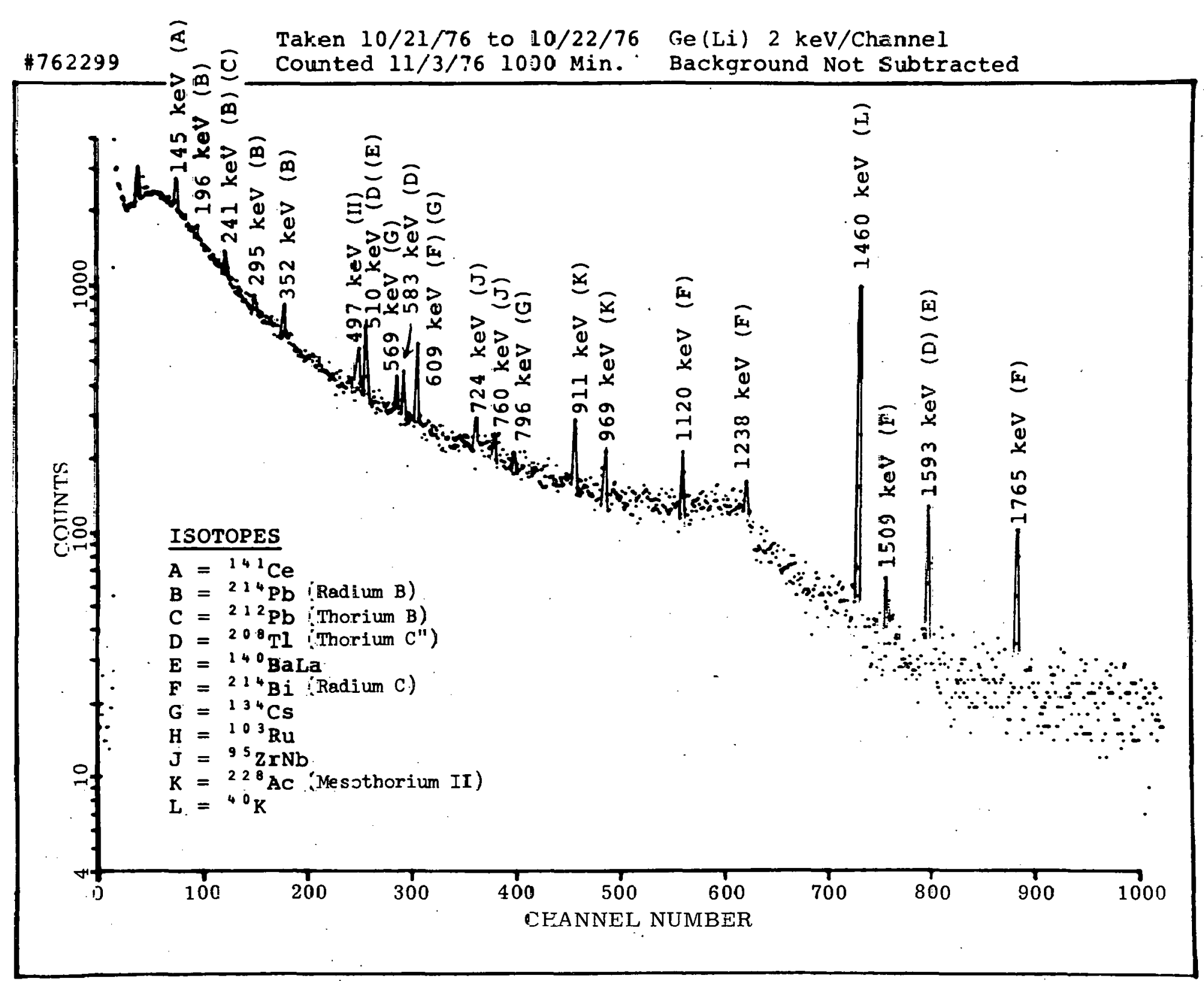

Figure 17. Air Sample From WIPP Meteorological Stazion 
Atmospheric samples are taken for the following pollutants: sulfur dioxide $\left(\mathrm{SO}_{2}\right)$, nitrogen dioxide $\left(\mathrm{NO}_{2}\right)$, hydrogen sulfide $\left(\mathrm{H}_{2} \mathrm{~S}\right)$, total weight particulate, carbon monoxide $(\mathrm{CO})$, and ozone $\left(\mathrm{O}_{3}\right)$. Air samplers are located on or above the roof of the meteorological instrument trailer (see Figure 18). The high-volume air-sample collection head is attached to the tower 4 feet above the trailer roof. The wet chemistry sampler is located about 3 feet above the trailer roof. The Sierra Cascade impactor is also located on the roof, with the collection surface located 2-1/2 feet above the roof. The sample inlet for the $\mathrm{CO}$ monitor is positioned inside the Sierra Cascade impactor housing and is 2 feet above the trailer. The ozone sample inlet is located at the roof level of the trailer. 


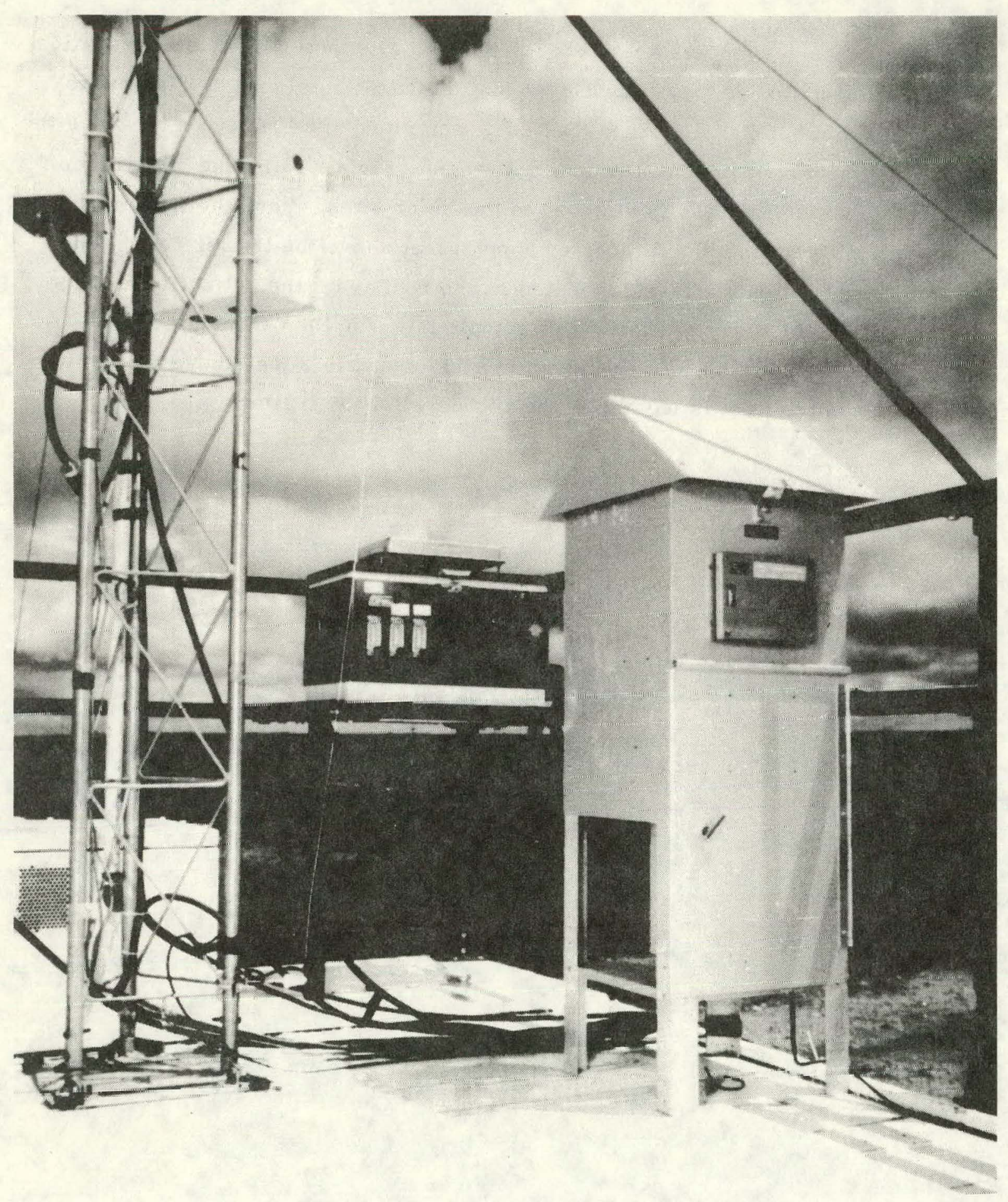

Figure 18. Air-Quality Instrumentation on Roof of Meteorological Station 


\section{ANALYSIS OF SAMPLES}

The total particulate samples are collected with the high-volume air sampler either on glass fiber (MSA \#1106BH w/o organic binder) or on Whatman \#414-inch filters. Samples are collected for 24 hours, with a constant $18.5-\mathrm{ft}^{3} / \mathrm{min}$ sampling rate used. These samples are collected 3 times per week. Each filter is weighed before collection and reweighed after sample collection, the total weight of particulate being the difference in weights. The total particulate samples are then analyzed for elemental composition, which includes sodium ( $\mathrm{Na}$ ), potassium (K), calcium ( $\mathrm{Ca})$, magnesium $(\mathrm{Mg})$, silicon $(\mathrm{Si})$, iron $(\mathrm{Fe})$, aluminum ( $\mathrm{Al}$ ), chloride $\mathrm{Cl}^{-}$) and sulfates $\left(\mathrm{SO}_{4}{ }^{-}\right.$). All chemical species are reported in micrograms per cubic metre of air sampled.

The analysis of high-volume filters consisted of a procedure to quantify both water- and acid-soluble metals, as well as sulfate and chloride levels. Water-soluble metals and sulfate and chloride were extracted from the filter media by heating in aqueous solution for 2 hours. Metals were quantified by atomic absorption spectrophotometry. Sulfates and chlorides were analyzed by turbimetric and colorimetric methods, respectively. Following aqueous extraction, the filters were completely digested in concentrated nitric acid, and the solutions were subsequently analyzed for acid-soluble metals by atomic absorption spectrophotometry.

The samples for $\mathrm{H}_{2} \mathrm{~S}, \mathrm{SO}_{2}$, and $\mathrm{NO}_{2}$ analyses are taken by wet chemistry methods one time per week on a random-day selection. The samples are collected for 24 hours at a sampling rate of approximately $200 \mathrm{~mL} / \mathrm{min}$ in high-efficiency bubblers containing appropriate collecting media. The $\mathrm{SO}_{2}$ and $\mathrm{NO}_{2}$ samples are analyzed colorimetrically and the $\mathrm{H}_{2} \mathrm{~S}$ sample is determined by titration (for methods, see Appendixes $A, B$, and $C$ ).

The carbon monoxide content of the ambient air is analyzed by means of an automatic nondispersive infrared analyzer that measures carbon monoxide levels continuously. The computer readout lists the carbon monoxide level measured on the hour, and the average for 24 hours is computed.

The ozone level in the air is measured continuously by means of an automated ultraviolet detector. The data are treated exactly as above for carbon monoxide. 
Air samples for particle size and mineralogical analysis, collected by the Sierra Cascade impactor of five stages for a 5- to 7-day period once each month, are being analyzed by the McCrone and Associates consulting firm. 


\section{CALIBRATION}

The two continuous monitors (for carbon monoxide and ozone), are calibrated weekly. The ozone monitor uses an electronic calibration system that applies to the detector a voltage equivalent to a known concentration of ozone in air. The carbon monoxide monitor is calibrated by means of a standardized $\mathrm{CO}$-in-nitrogen gas.

The high-volume air sampler and the Sierra Cascade impactor use electronic flow controllers to assure constant flow, regardless of filter resistance.

The wet chemical methods are standardized through the use of known concentrations of $\mathrm{SO}_{2}, \mathrm{NO}_{2}$, and $\mathrm{H}_{2} \mathrm{~S}$ to prepare standard curves to which the atmospheric samples are compared. 


\section{RESULTS}

Ozone concentrations for the sampling period June 11 through December 31 , 1976, are shown in Tables IV through X. Hours where the ozone concentration exceeded the allowable level* are marked. As can be noted, the ozone levels generally peak during the afternoon and with an average wind direction of $146^{\circ}$ (from the southeast). The ozone concentrations appear to be temperature-dependent, with the ozone levels increasing as the temperature increases. The average monthly diurnal concentrations of ozone are shown in Figures 19-25.

Carbon monoxide concentrations from June 11 thrnigh nerember 31, 1976, aro shown in Tables XI through XVII. The carbon monoxide levels usually peak during the morning hours and when the wind direction is $150^{\circ}$. The diurnal variations of the concentrations of carbon monoxide are shown in Figures 26-32.

The data for $\mathrm{SO}_{2}, \mathrm{NO}_{2}$, and $\mathrm{H}_{2} \mathrm{~S}$ will be found graphically in Figures 33,34 , and 35 . Since the analyses are not continuous, the data indicate only the average level present during actual sampling. The average 24-hour concentrations for the period sampled are:

$$
\begin{aligned}
& \mathrm{NO}_{2}-32.19 \mu \mathrm{g} / \mathrm{m}^{3} \\
& \mathrm{SO}_{2}-4.29 \mu \mathrm{g} / \mathrm{m}^{3} \\
& \mathrm{H}_{2} \mathrm{~S}-0.110 \mu \mathrm{g} / \mathrm{m}^{3}
\end{aligned}
$$

The data from the analyses of particulate matter are found in Table XVIII. No specific mineralogical analysis has been performed; however, seven scts of sized samples have been collected.

\footnotetext{
*See Appendix D for. Federal and State Standards.
} 
TABLE IV.

Ozone Concentration (ppm) for June 1976

\begin{tabular}{|c|c|c|c|c|c|}
\hline Date & $\begin{array}{l}\text { Time of } \\
\text { Maximum }\end{array}$ & $\begin{array}{l}\text { Wind Direction } \\
\text { for Maximum } \\
\left({ }^{\circ}\right)\end{array}$ & $\begin{array}{l}\text { 24-Hour } \\
\text { Maximum }\end{array}$ & $\begin{array}{l}\text { 24-Hour } \\
\text { Minimum }\end{array}$ & 24-Hour Average \\
\hline $6 / 11$ & 0900 & 164 & 0.015 & 0 & 0.005 \\
\hline $6 / 12$ & 0800 & 346 & 0.016 & 0 & 0.002 \\
\hline $6 / 13$ & 1000 & 194 & 0.026 & 0 & 0.012 \\
\hline $6 / 14$ & $\begin{array}{l}1000 \\
1100\end{array}$ & $\begin{array}{l}265 \\
270\end{array}$ & $\begin{array}{l}0.025 \\
0.025\end{array}$ & 0.006 & 0.013 \\
\hline $6 / 15$ & 1700 & 53 & 0.038 & 0 & 0.017 \\
\hline $6 / 16$ & $\begin{array}{l}1100 \\
1200\end{array}$ & $\begin{array}{l}172 \\
175\end{array}$ & $\begin{array}{l}0.045 \\
0.045\end{array}$ & 0.001 & 0.025 \\
\hline $6 / 17$ & 1400 & 162 & 0.048 & 0.016 & 0.030 \\
\hline $6 / 18$ & 1700 & 29 & 0.054 & 0.015 & 0.031 \\
\hline $6 / 19$ & 2000 & 135 & 0.064 & 0.024 & 0.040 \\
\hline $6 / 20$ & 1800 & 141 & 0.052 & 0.028 & 0.040 \\
\hline $6 / 21$ & 1300 & 205 & 0.043 & 0.020 & 0.033 \\
\hline $6 / 22$ & 1900 & 270 & 0.038 & 0.012 & 0.022 \\
\hline $6 / 23$ & 2000 & 268 & 0.044 & 0.016 & 0.029 \\
\hline $6 / 24$ & 1300 & 34 & 0.056 & 0.003 & 0.033 \\
\hline $6 / 25$ & 1400 & 130 & 0.051 & 0.015 & 0.034 \\
\hline $6 / 26$ & 1800 & 113 & 0.044 & 0.014 & 0.039 \\
\hline $6 / 27$ & 1500 & 135 & 0.039 & 0.009 & 0.030 \\
\hline $6 / 28$ & $\begin{array}{l}1600 \\
1700\end{array}$ & $\begin{array}{l}157 \\
108\end{array}$ & $\begin{array}{l}0.035 \\
0.035\end{array}$ & 0.009 & 0.022 \\
\hline $6 / 29$ & 1300 & 140 & 0.042 & 0.013 & 0.027 \\
\hline $6 / 30$ & 1400 & 124 & 0.048 & 0.011 & 0.029 \\
\hline & verage June & $165^{\circ}$ & 0.040 & 0.011 & 0.026 \\
\hline
\end{tabular}


TABLE V

Ozone Concentration (ppm) for July 1976

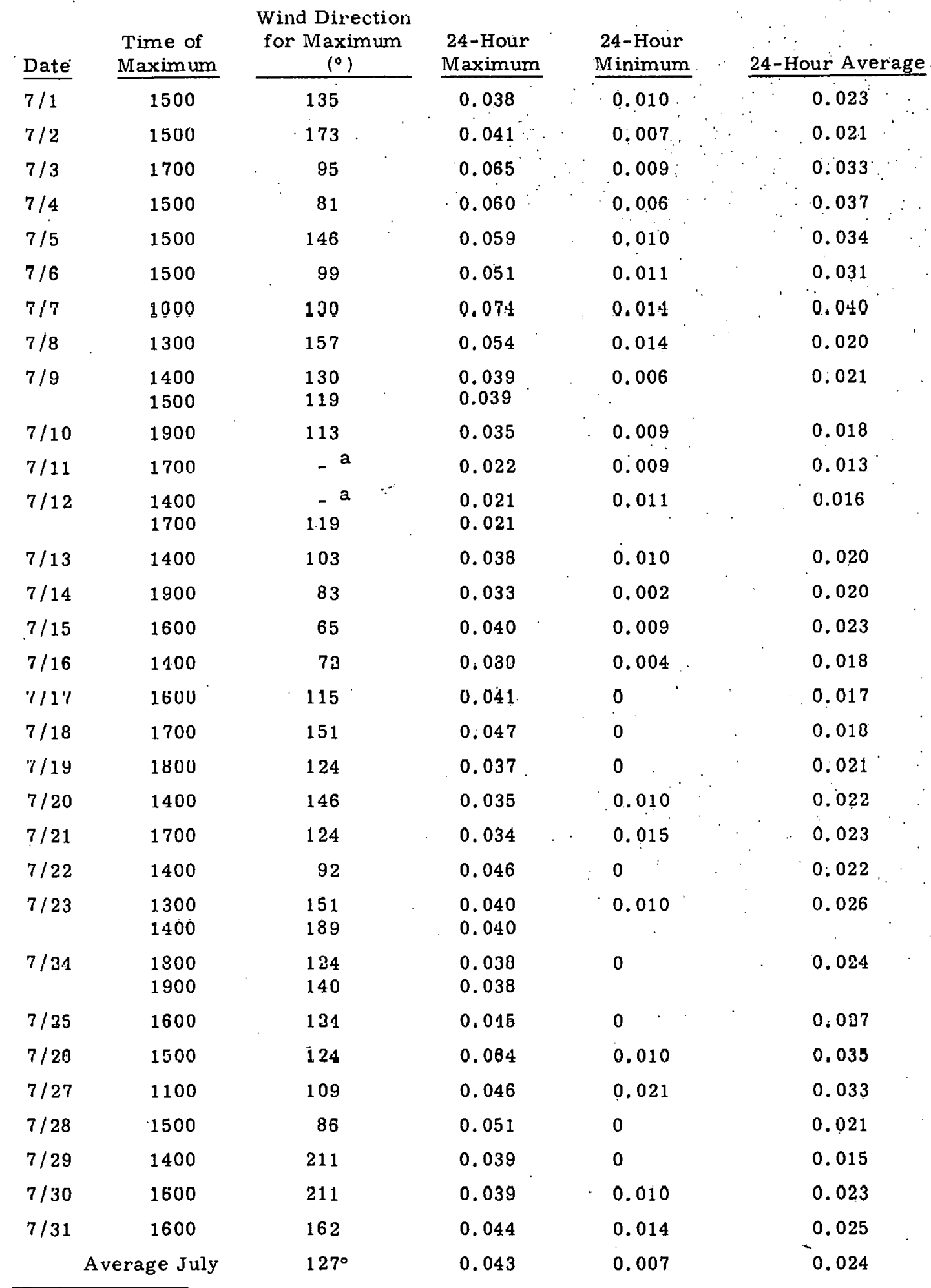

\footnotetext{
${ }^{\mathrm{a}}$ No wind direction data recorded.
} 
TABLE VI

Ozone Concentration (ppm) for August 1976

\begin{tabular}{|c|c|c|c|c|c|}
\hline Date & $\begin{array}{l}\text { Time of } \\
\text { Maximum }\end{array}$ & $\begin{array}{l}\text { Wind Direction } \\
\text { for Maximum } \\
\left(^{\circ}\right)\end{array}$ & $\begin{array}{c}\text { 24-Hour } \\
\text { Maximum } \\
\end{array}$ & $\begin{array}{l}\text { 24-Hour } \\
\text { Minimum }\end{array}$ & 24-Hour Average \\
\hline $8 / 1$ & 1400 & 130 & 0.047 & 0.006 & 0.027 \\
\hline $8 / 2$ & 1300 & 135 & 0.042 & 0.015 & 0.025 \\
\hline $8 / 3$ & $\begin{array}{l}1300 \\
1400\end{array}$ & $\begin{array}{l}167 \\
167\end{array}$ & $\begin{array}{l}0.048 \\
0.048\end{array}$ & 0.002 & 0.027 \\
\hline $8 / 4$ & 1200 & 178 & 0.035 & 0.012 & 0.027 \\
\hline $8 / 5$ & 1300 & 286 & 0.040 & 0.009 & 0.029 \\
\hline $8 / 6$ & 1700 & 135 & 0.052 & 0.014 & 0.034 \\
\hline $8 / 7$ & $\begin{array}{l}1400 \\
1500\end{array}$ & $\begin{array}{l}173 \\
151\end{array}$ & $\begin{array}{l}0.043 \\
0.043\end{array}$ & 0.018 & 0.033 \\
\hline $8 / 8$ & $\begin{array}{l}1300 \\
2100\end{array}$ & $\begin{array}{l}113 \\
124\end{array}$ & $\begin{array}{l}0.040 \\
0.040\end{array}$ & 0.011 & 0,028 \\
\hline $8 / 9$ & 1500 & 178 & 0.040 & 0.018 & 0.032 \\
\hline $8 / 10$ & 1900 & 133 & 0.043 & 0,025 & 0.036 \\
\hline $8 / 11$ & $\begin{array}{l}1400 \\
1500\end{array}$ & $\begin{array}{l}157 \\
124\end{array}$ & $\begin{array}{l}0.045 \\
0.045\end{array}$ & 0.017 & 0.037 \\
\hline $8 / 12$ & 1000 & 130 & 0.060 & 0.026 & 0.043 \\
\hline $8 / 13$ & 1700 & 151 & 0.054 & 0.023 & 0.036 \\
\hline $8 / 14$ & 1500 & 126 & 0.050 & 0.012 & 0.030 \\
\hline $8 / 15$ & 1500 & 89 & 0.047 & 0.011 & 0.026 \\
\hline $8 / 16$ & 1600 & 0 & 0.036 & 0.012 & 0.024 \\
\hline $8 / 17$ & 1700 & 130 & 0.042 & 0.016 & 0.025 \\
\hline $8 / 18$ & 1500 & 140 & 0.039 & 0.003 & 0.020 \\
\hline $8 / 19$ & 1500 & 140 & 0.062 & 0.004 & 0.030 \\
\hline $8 / 20$ & 1700 & 157 & 0.057 & 0.019 & 0.043 \\
\hline $8 / 21$ & 1800 & 146 & 0.055 & 0.035 & 0.046 \\
\hline $8 / 22$ & 1800 & 108 & 0.064 & 0.029 & 0.017 \\
\hline $8 / 23$ & 1800 & 140 & 0.061 & 0.017 & 0.042 \\
\hline $8 / 24$ & 1500 & 142 & 0.061 & 0.016 & 0.040 \\
\hline $8 / 25$ & 1300 & 124 & 0.060 & 0.017 & 0.042 \\
\hline $8 / 26$ & 1300 & 178 & 0.052 & 0.016 & 0.036 \\
\hline $8 / 27$ & $\begin{array}{l}1600 \\
2100\end{array}$ & $\begin{array}{r}184 \\
81\end{array}$ & $\begin{array}{l}0.037 \\
0.037\end{array}$ & 0.010 & 0.024 \\
\hline $8 / 28$ & 1600 & 83 & $0.03+8$ & 0.001 & 0.022 \\
\hline $8 / 29$ & 2000 & 92 & 0.043 & 0 & 0.023 \\
\hline $8 / 30$ & 2000 & 140 & 0.048 & 0.011 & 0.028 \\
\hline $8 / 31$ & 2200 & 61 & 0.044 & 0.007 & 0.027 \\
\hline & Average August & $136^{\circ}$ & 0.047 & 0.014 & 0.032 \\
\hline
\end{tabular}


TABLE VII

Ozone Concentration (ppm) for September 1976

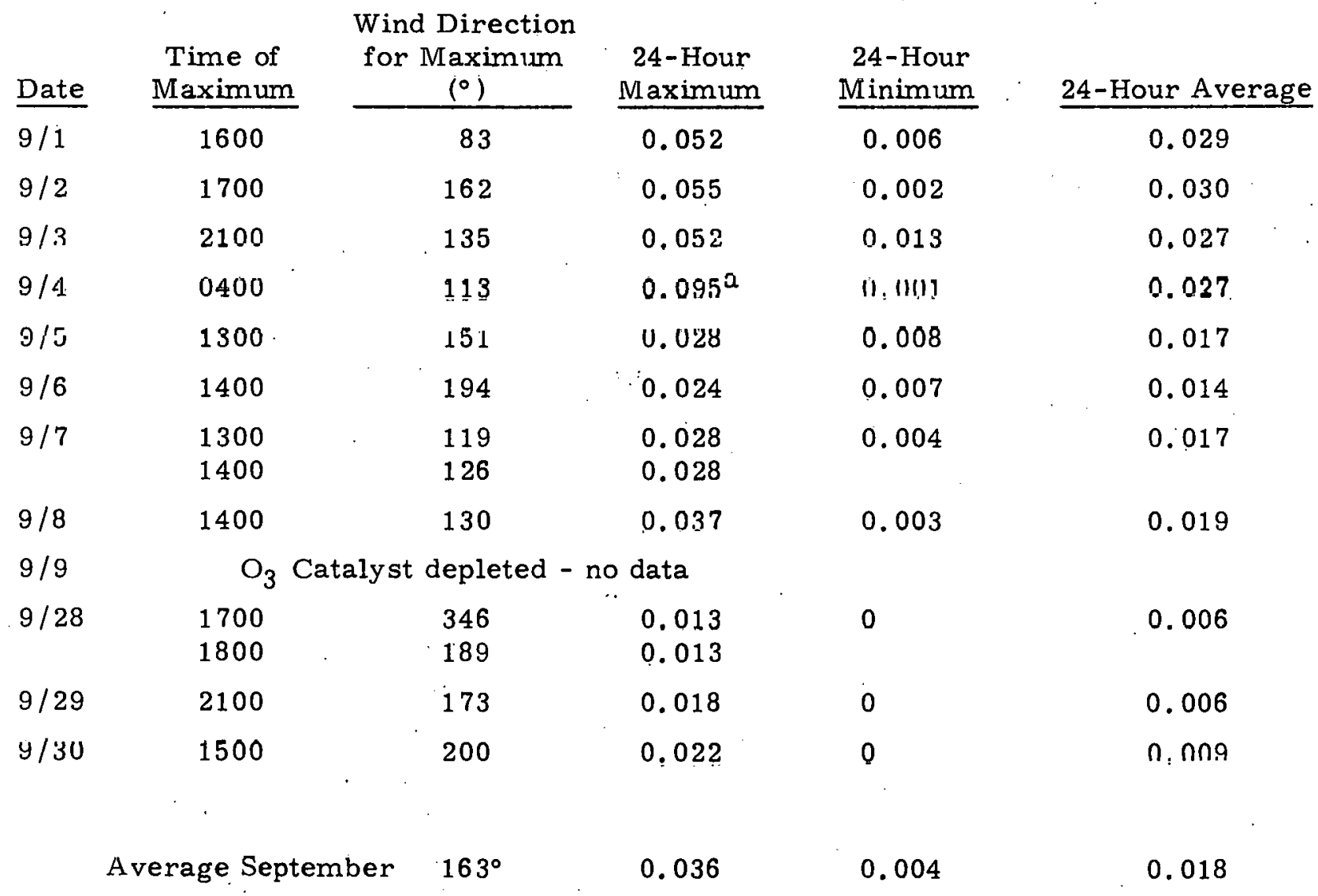

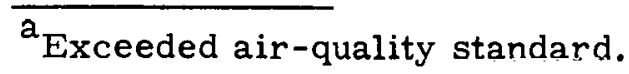


TABLE VIII

Ozone Concentration (ppm) for October 1976

\begin{tabular}{|c|c|c|c|c|c|c|}
\hline Date & $\begin{array}{l}\text { Time of } \\
\text { Maximum }\end{array}$ & & $\begin{array}{l}\text { Wind Direction } \\
\text { for Maximum } \\
\left(^{\circ}\right) \\
\end{array}$ & $\begin{array}{l}\text { 24-Hour } \\
\text { Maximum } \\
\end{array}$ & $\begin{array}{l}\text { 24-Hour } \\
\text { Minimum } \\
\end{array}$ & 24-Hour Average \\
\hline $10 / 1$ & 0800 & & 113 & 0.033 & 0.006 & 0.017 \\
\hline $10 / 2$ & 0700 & & .135 & 0.025 & 0.004 & 0.013 \\
\hline $10 / 3$ & $\begin{array}{l}1500 \\
1700\end{array}$ & & $\begin{array}{l}227 \\
238\end{array}$ & $\begin{array}{l}0.014 \\
0.014\end{array}$ & 0 & 0.008 \\
\hline $10 / 4$ & 1400 & & 335 & 0.018 & 0.001 & 0.010 \\
\hline $10 / 5$ & 1800 & & 108 & 0.021 & 0 & 0.010 \\
\hline $10 / 6$ & $\begin{array}{l}1400 \\
2200\end{array}$ & & $\begin{array}{r}184 \\
50\end{array}$ & $\begin{array}{l}0.020 \\
0.020\end{array}$ & 0.007 & 0.013 \\
\hline $10 / 7$ & 0000 & & 23 & 0.016 & 0.003 & 0.008 \\
\hline $10 / 8$ & 1200 & & 205 & 0.012 & 0 & 0.006 \\
\hline $10 / 9$ & 1700 & & 146 & 0.028 & 0 & 0.012 \\
\hline $10 / 10$ & 1000 & & 173 & 0.023 & 0 & 0.011 \\
\hline $10 / 11$ & $\begin{array}{l}1200 \\
1300\end{array}$ & . & $\begin{array}{l}162 \\
184\end{array}$ & $\begin{array}{l}0.031 \\
0.031\end{array}$ & 0 & 0.012 \\
\hline $10 / 12$ & 1600 & & 115 & 0.031 & 0.002 & 0.014 \\
\hline $10 / 13$ & 1200 & & 86 & 0.020 & 0 & 0.014 \\
\hline $10 / 14$ & 2100 & & 140 & 0.031 & 0.004 & 0.014 \\
\hline $10 / 15$ & $\begin{array}{l}1300 \\
1700\end{array}$ & . & $\begin{array}{r}56 \\
7\end{array}$ & $\begin{array}{l}0.015 \\
0.015\end{array}$ & . & 0.008 \\
\hline $10 / 16$ & 1700 & & 162 & 0.024 & 0 & 0.009 \\
\hline $10 / 17$ & 1900 . & . & 130 & 0.039 & 0.003 & 0.020 \\
\hline $10 / 18$ & 1600 & & 270 & 0.033 & 0.002 & 0.016 \\
\hline $10 / 19$ & 0300 & $\cdot$ & 7 & 0.022 & 0.001 & 0.010 \\
\hline $10 / 20$ & 1700 & 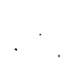 & 140 & 0.071 & 0 & 0.021 \\
\hline $10 / 21$ & 2200 & $\cdot$ & 124 & 0.032 & 0 & 0.018 \\
\hline $10 / 22$ & 0100 & & 130 & 0.040 & U. UU1 & Ù. Ũig \\
\hline $10 / 23$ & 1700. & : . & 227 & 0.029 & 0 & 0.010 \\
\hline $10 / 24$ & 2200 & $\therefore$ & 94 & 0.017 & 0 & 0.007 \\
\hline $10 / 25$ & 2200 & $\therefore$ & 135 & 0.029 & 0 & 0.016 \\
\hline $10 / 26$ & 1100 & . & 281 & 0.028 & 0 & 0.015 \\
\hline $10 / 27$ & 1700 & $\cdot$ & 34 & 0.021 & 0 & 0.008 \\
\hline $10 / 28$ & 0800 & & 77 & 0.025 & 0 & 0.013 \\
\hline $10 / 29$ & 1700 & 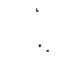 & 270 & 0.030 & 0.001 & 0.010 \\
\hline $10 / 30$ & 1400 & . & 281 & 0.028 & 0.001 & 0.010 \\
\hline $10 / 31$ & 1400 & $\therefore$ & 115 & 0.040 & 0.006 & 0.023 \\
\hline Aver & ge October & & $148^{\circ}$ & 0.027 & 0.001 & 0.013 \\
\hline
\end{tabular}


TABLE IX

Ozone Concentration (ppm) for November 1976

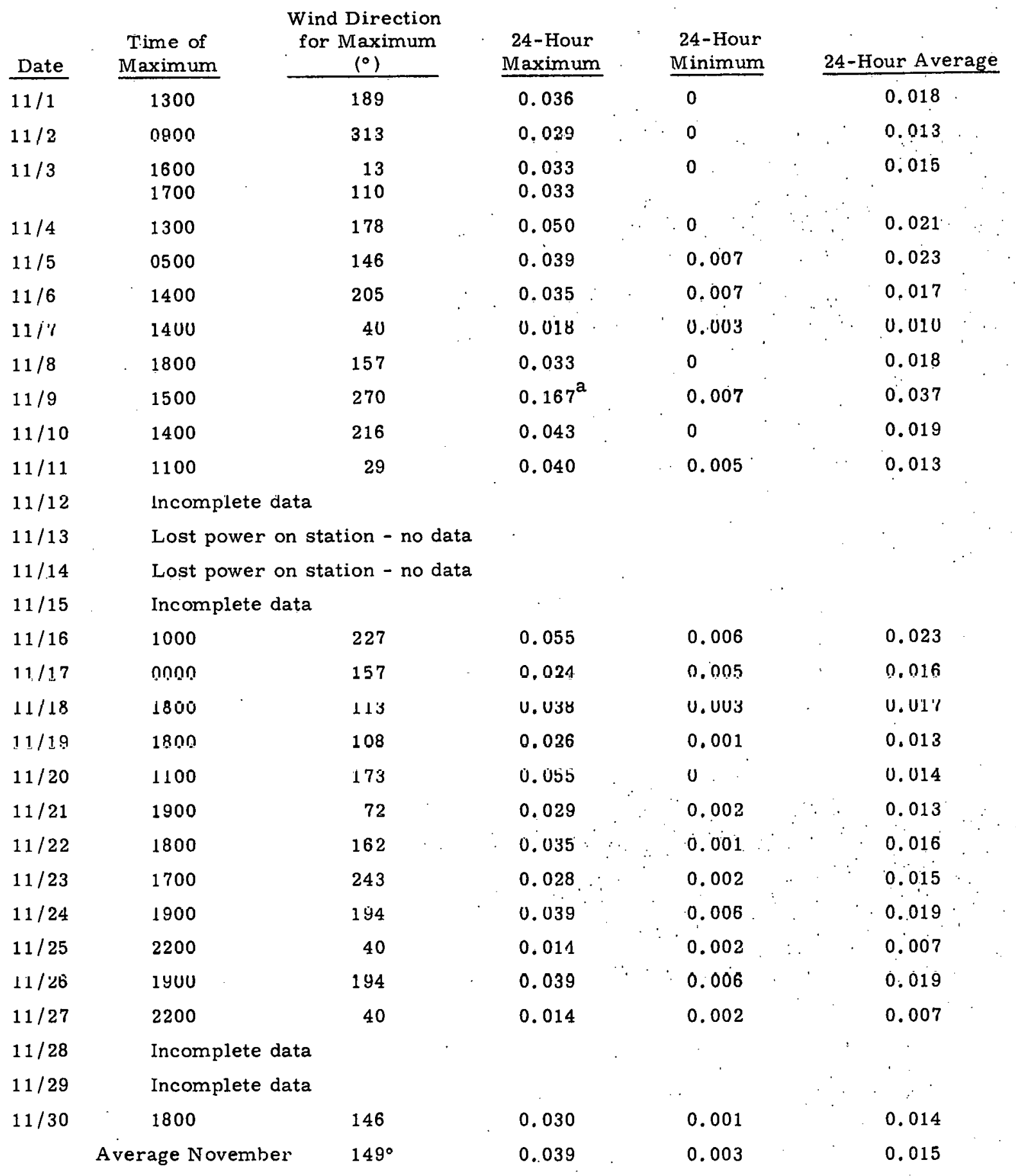

$\overline{a_{\text {Exceeded air-quality standard. }} .}$ 
TABLE $X$

Ozone Concentration (ppm) for December 1976

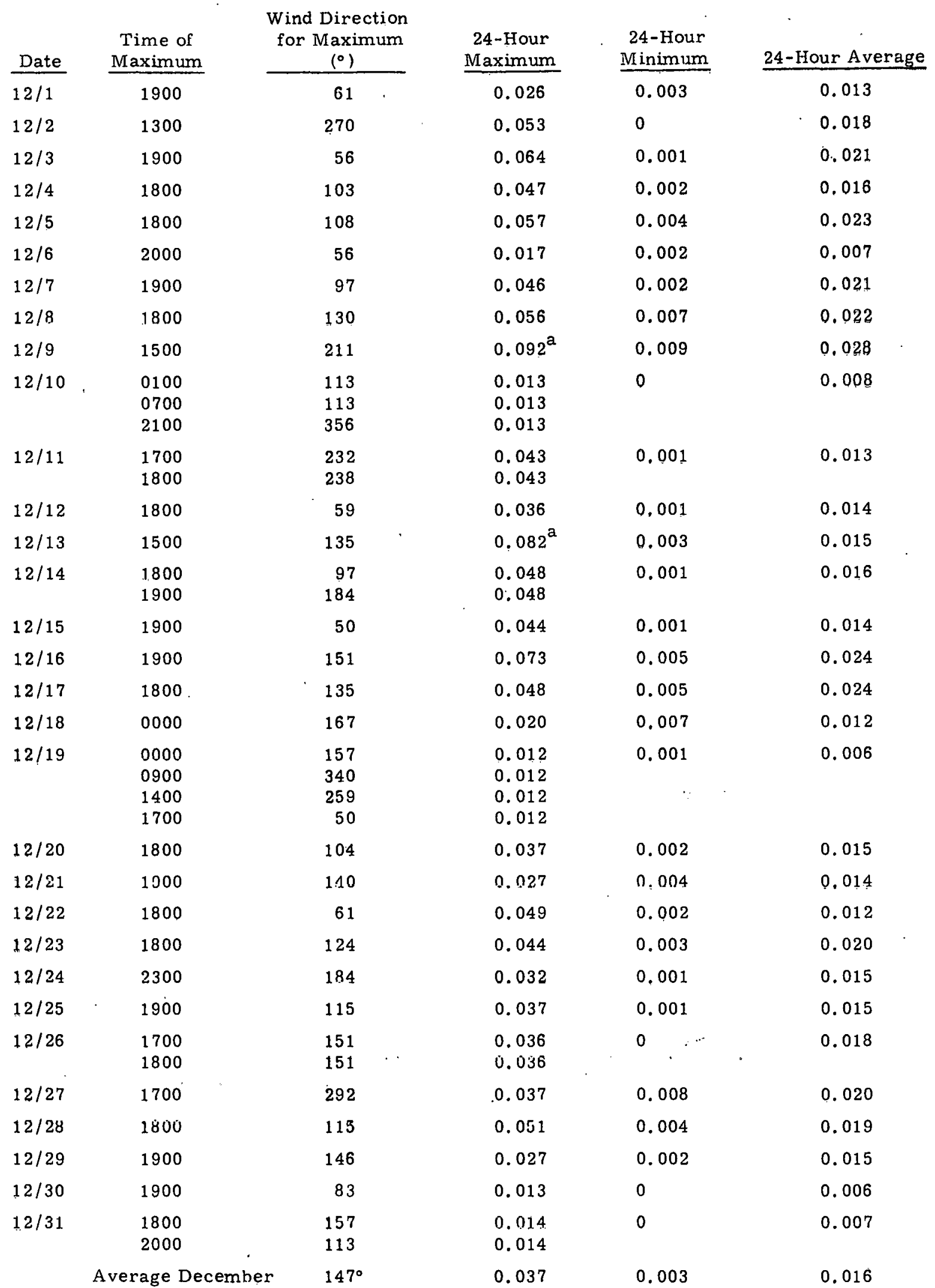

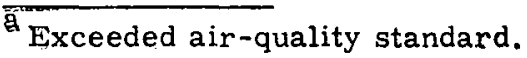




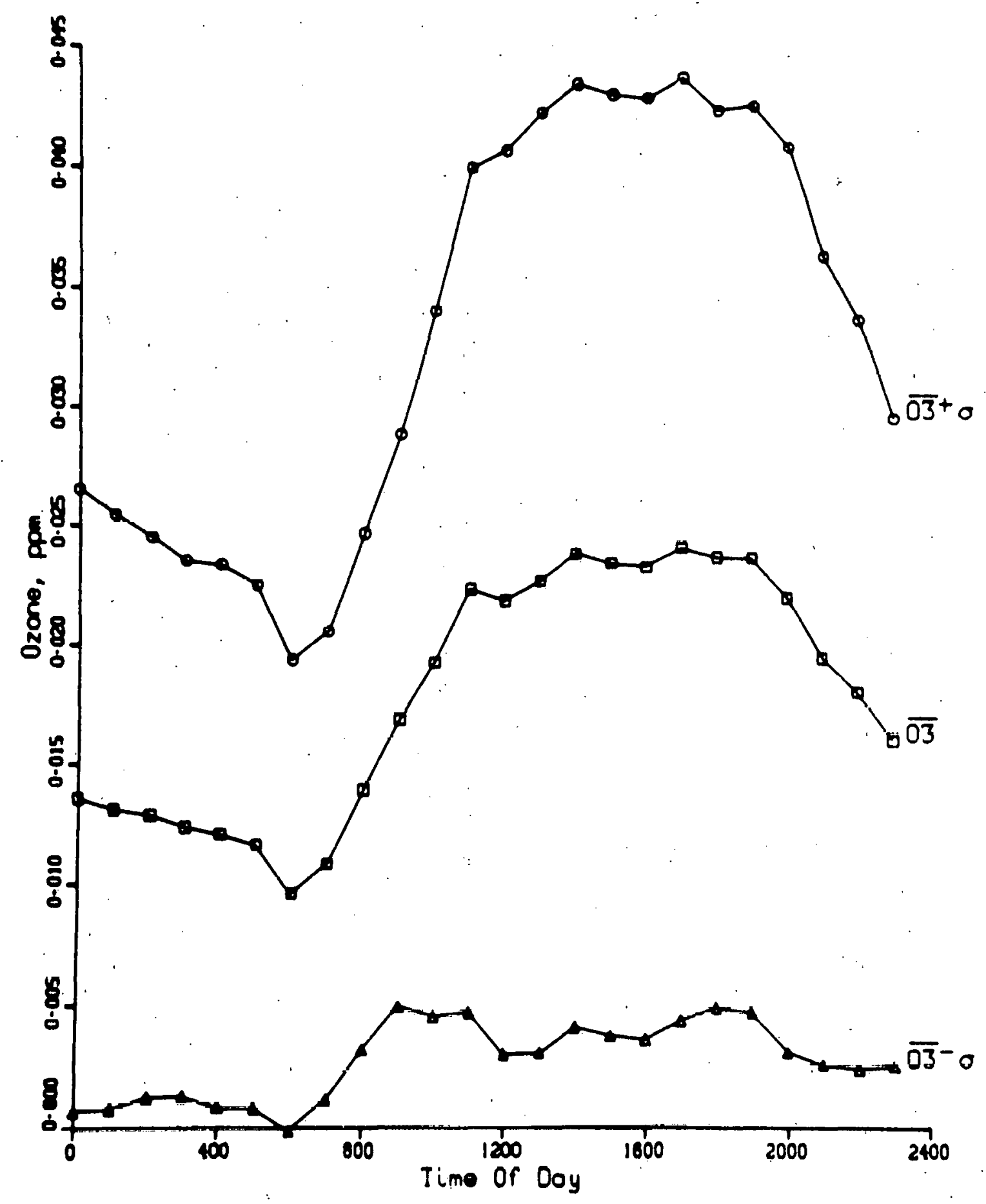

Figure 19. Diurnal Variation in Ozone, June 1976 


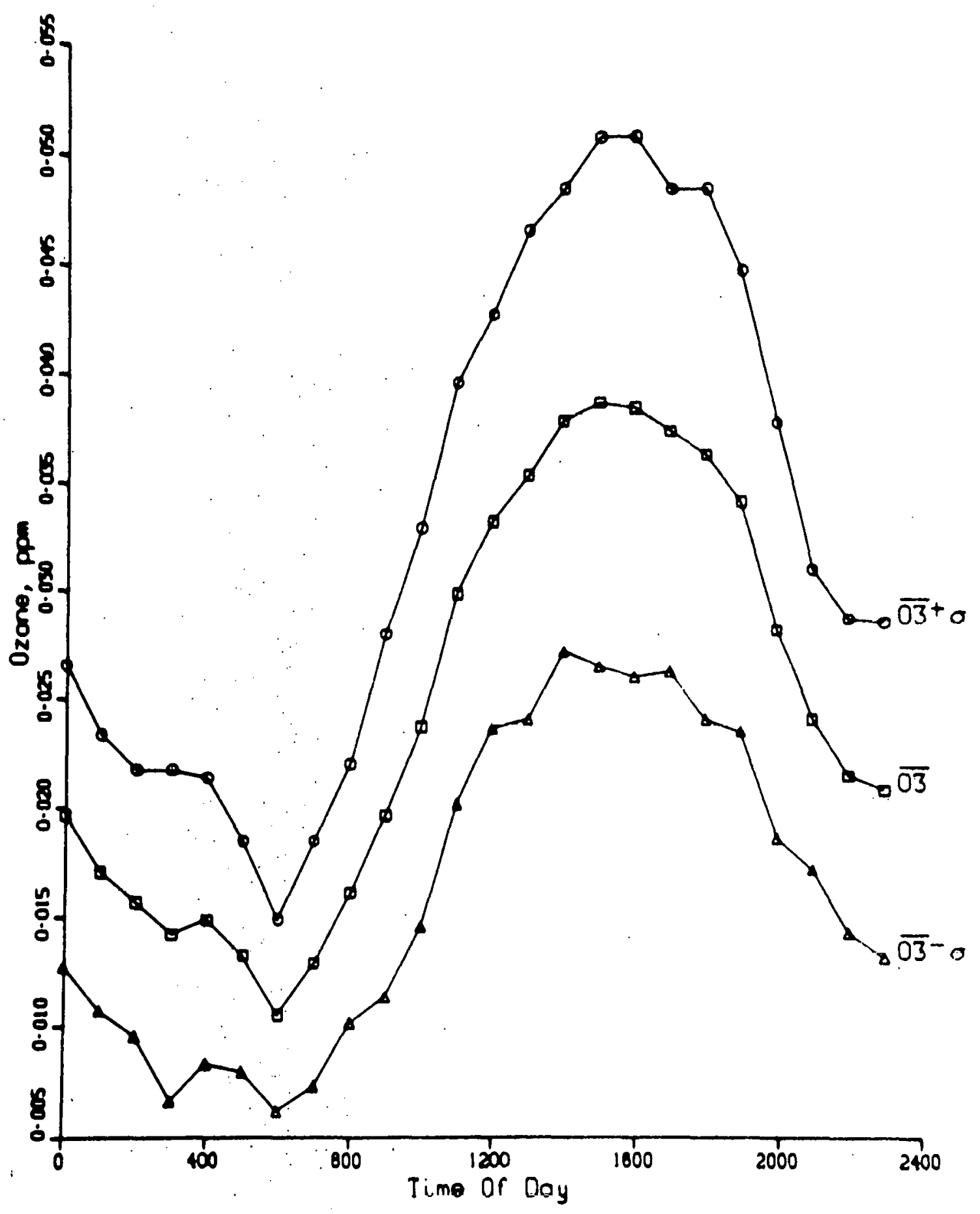

Figure 20. Diurnal Variation in Ozone, July 1976 


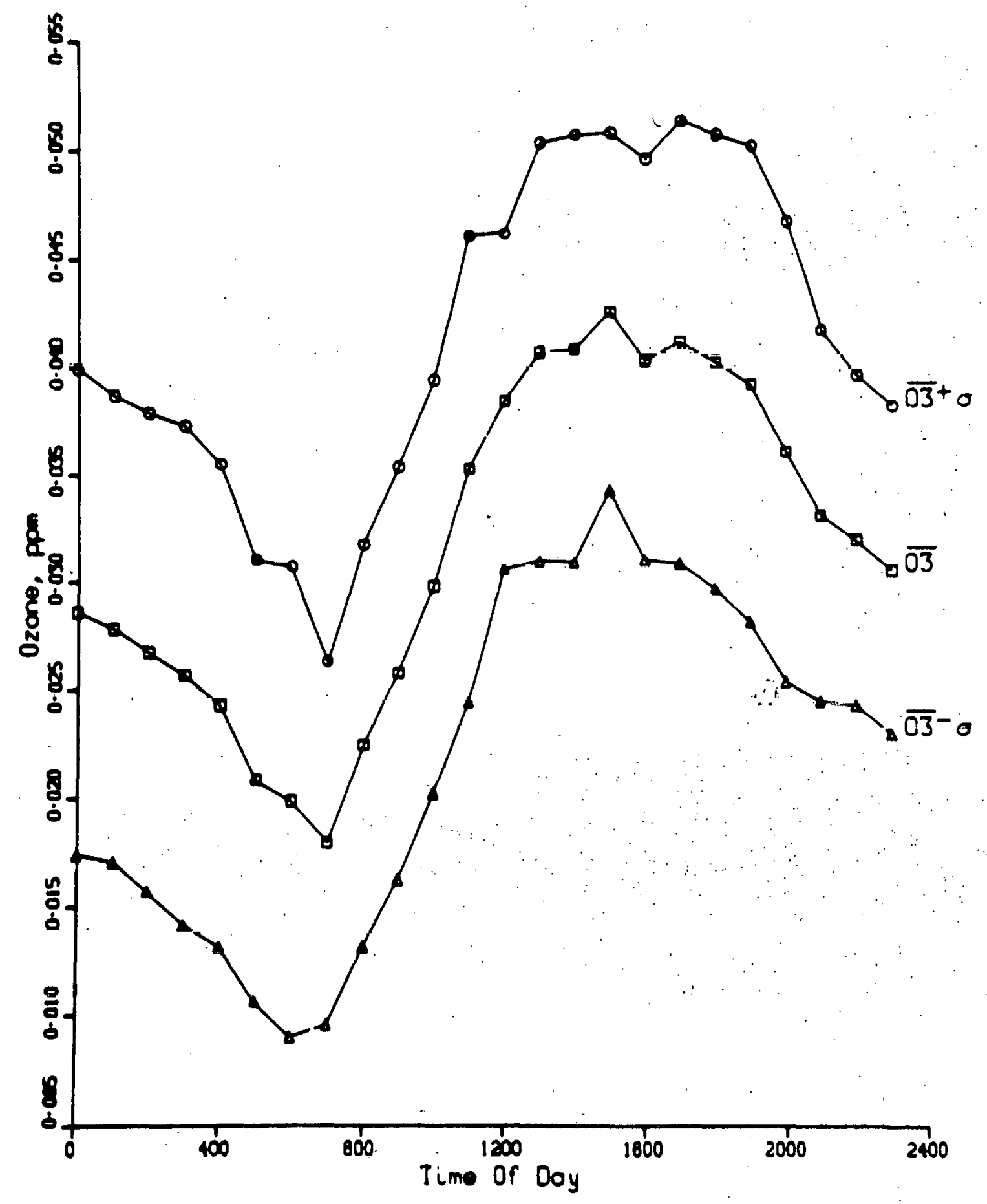

Figure 21. Diurnal Variation in Ozone, August 1976 


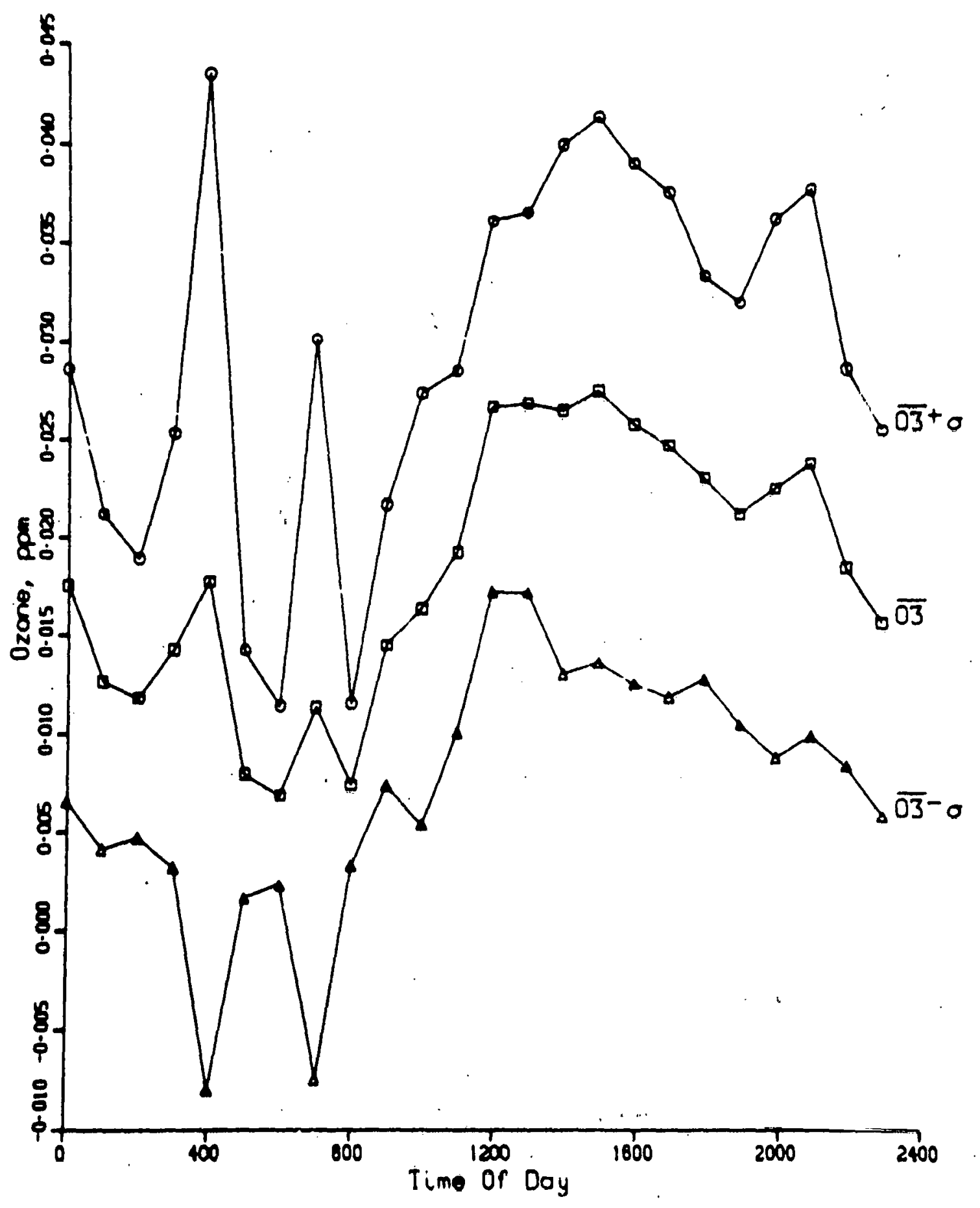

Figure 22. Diurnal Variation in Ozone; September 1976 


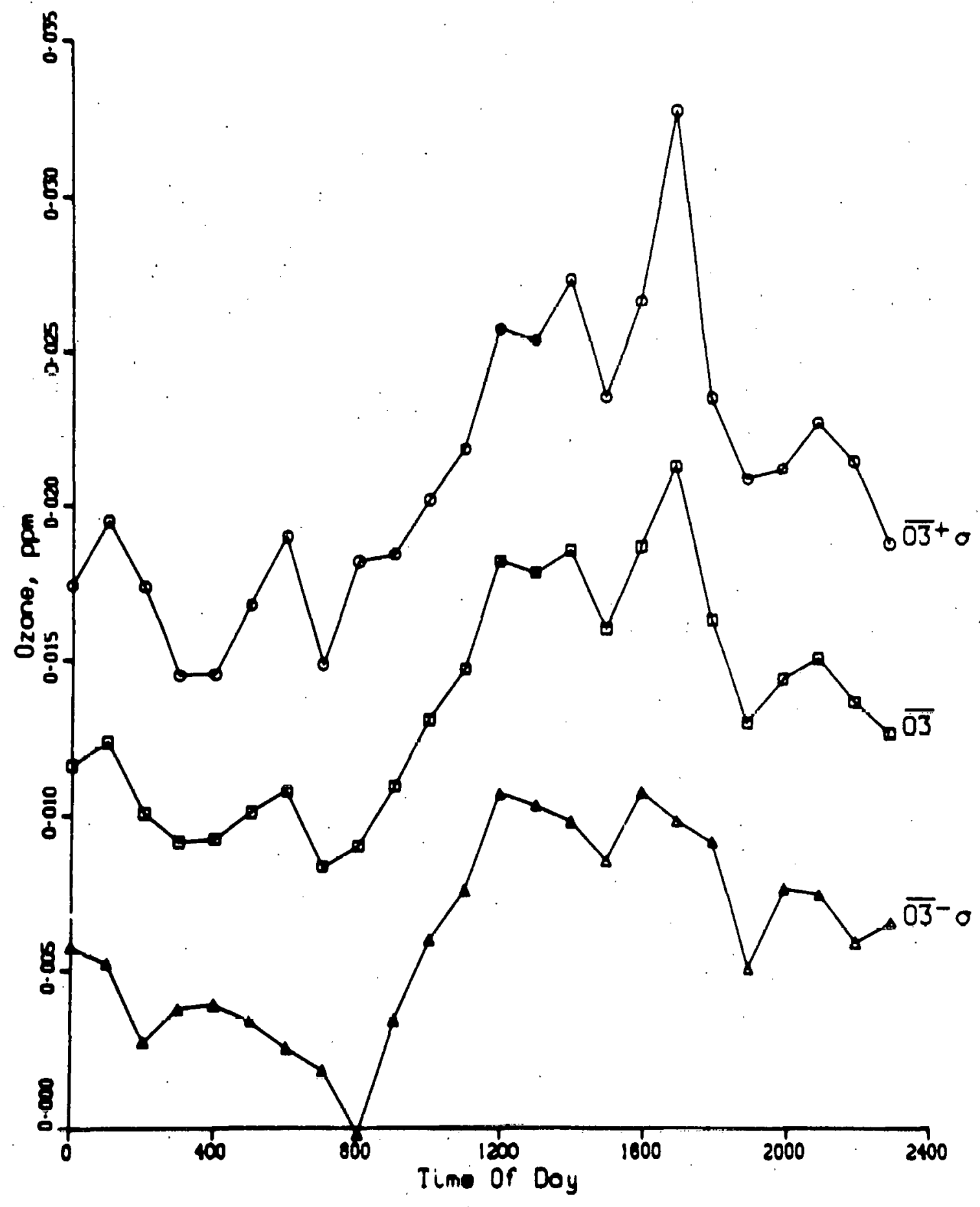

Figure 23. Diurnal Variation in Ozone, October 1976 


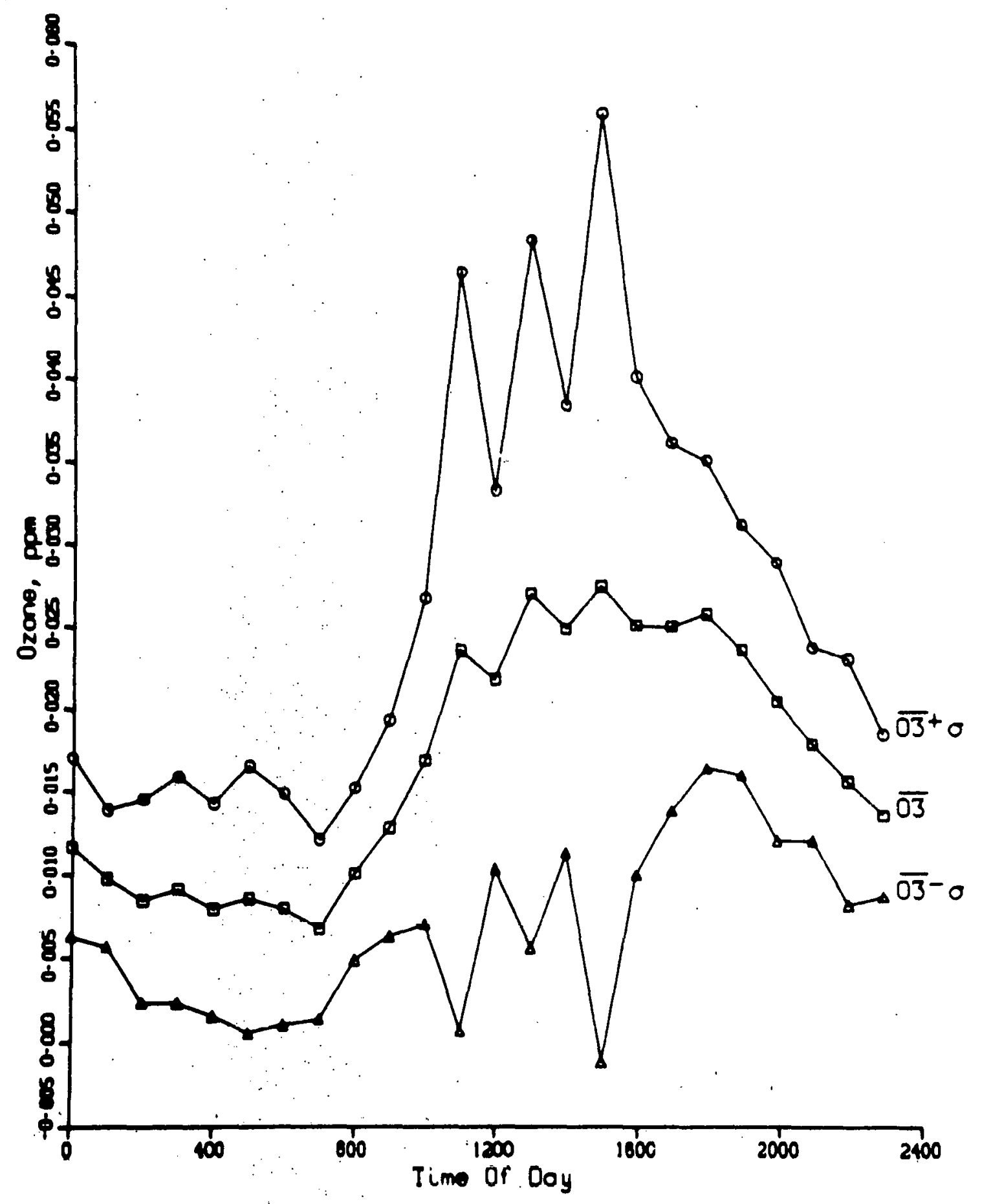

Figure 24: Diurnal Variation in Ozone, November 1976 


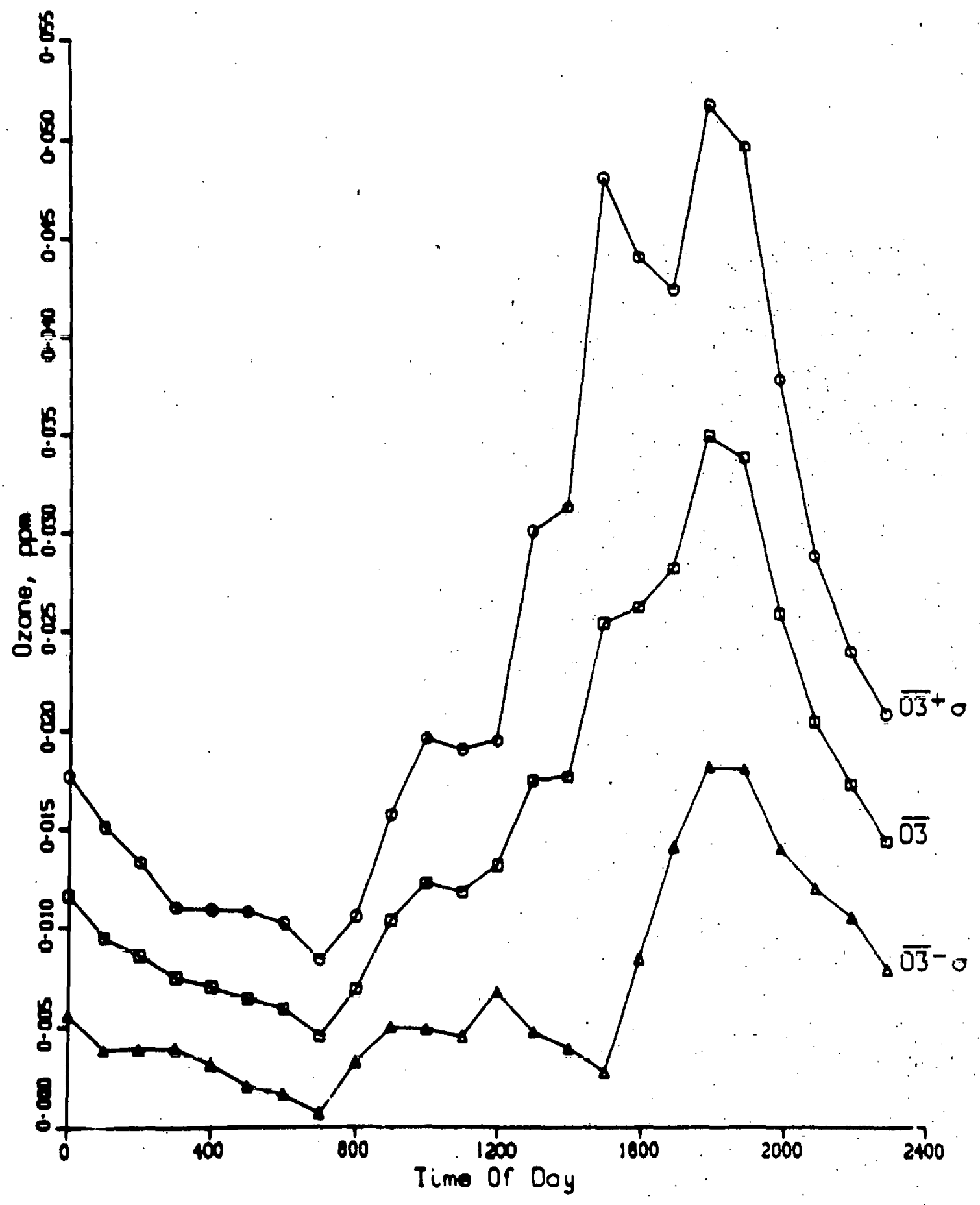

Figure 25. Diurnal Variation in Ozone, December 1976 
TABLE XI

Carbon Monoxide Concentration (ppm) for June 1976

\begin{tabular}{|c|c|c|c|c|c|}
\hline Date & $\begin{array}{l}\text { Time of } \\
\text { Maximum }\end{array}$ & $\begin{array}{l}\text { Wind Direction } \\
\text { for Maximum } \\
\left(^{\circ}\right)\end{array}$ & $\begin{array}{l}\text { 24-Hour } \\
\text { Maximum } \\
\end{array}$ & $\begin{array}{l}24 \text {-Hour } \\
\text { Minimum } \\
\end{array}$ & 24-Hour Average \\
\hline $6 / 11$ & 0800 & 166 & 11 & 1 & 5 \\
\hline $6 / 12$ & 0700 & 351 & 12 & 4 & 8 \\
\hline $6 / 13$ & 0800 & 135 & 14 & 9 & 12 \\
\hline $6 / 14$ & $\begin{array}{l}0300 \\
0500\end{array}$ & $\begin{array}{l}157 \\
135\end{array}$ & $\begin{array}{l}15 \\
15\end{array}$ & $\begin{array}{l}0 \\
0\end{array}$ & $\begin{array}{l}7 \\
7\end{array}$ \\
\hline $6 / 15$ & 1700 & 53 & 4 & 0 & 2 \\
\hline $6 / 16$ & $\begin{array}{l}0400 \\
0700\end{array}$ & $\begin{array}{l}104 \\
125\end{array}$ & $\begin{array}{l}4 \\
4\end{array}$ & $\begin{array}{l}0 \\
0\end{array}$ & $\begin{array}{l}2 \\
2\end{array}$ \\
\hline $6 / 17$ & $\begin{array}{l}2000 \\
2200\end{array}$ & $\begin{array}{l}140 \\
135\end{array}$ & $\begin{array}{l}9 \\
9\end{array}$ & $\begin{array}{l}0 \\
0\end{array}$ & $\begin{array}{l}5 \\
5\end{array}$ \\
\hline $6 / 18$ & $\begin{array}{l}0000 \\
0100 \\
0200 \\
0300\end{array}$ & $\begin{array}{l}135 \\
135 \\
140 \\
140\end{array}$ & $\begin{array}{l}8 \\
8 \\
8 \\
8\end{array}$ & $\begin{array}{l}5 \\
5 \\
5 \\
5\end{array}$ & $\begin{array}{l}7 \\
7 \\
7 \\
7\end{array}$ \\
\hline $6 / 19$ & $\begin{array}{l}0300 \\
0900 \\
1000\end{array}$ & $\begin{array}{l}56 \\
77 \\
86\end{array}$ & $\begin{array}{l}8 \\
8 \\
8\end{array}$ & $\begin{array}{l}6 \\
6 \\
6\end{array}$ & $\begin{array}{l}7 \\
7 \\
7\end{array}$ \\
\hline $6 / 20$ & 1100 & 149 & 9 & 6 & 7 \\
\hline $6 / 21$ & 0700 & 121 & 9 & 3 & 6 \\
\hline $6 / 22$ & 0800 & 146 & 8 & 5 & 6 \\
\hline $6 / 23$ & 1000 & 162 & 8 & 3 & 6 \\
\hline $6 / 24$ & $\begin{array}{l}0000 \\
1.100\end{array}$ & $\begin{array}{r}130 \\
2\end{array}$ & $\begin{array}{l}8 \\
8\end{array}$ & $\begin{array}{l}5 \\
5\end{array}$ & $\begin{array}{l}6 \\
6\end{array}$ \\
\hline $6 / 25$ & $\begin{array}{l}0800 \\
1000\end{array}$ & $\begin{array}{r}94 \\
108\end{array}$ & $\begin{array}{l}9 \\
9\end{array}$ & $\begin{array}{l}5 \\
5\end{array}$ & $\begin{array}{l}7 \\
7\end{array}$ \\
\hline $6 / 26$ & 1200 & 140 & 9 & 6 & 7 \\
\hline $6 / 27$ & 1100 & 140 & 11 & 1 & 8 \\
\hline $6 / 28$ & $\begin{array}{l}0300 \\
0400 \\
0800 \\
1000\end{array}$ & $\begin{array}{r}130 \\
130 \\
124 \\
113\end{array}$ & $\begin{array}{l}10 \\
10 \\
10 \\
10\end{array}$ & $\begin{array}{l}6 \\
6 \\
6 \\
6\end{array}$ & $\begin{array}{l}8 \\
8 \\
8 \\
8\end{array}$ \\
\hline $6 / 29$ & 0300 & 130 & 10 & 6 & 8 \\
\hline $6 / 30$ & $\begin{array}{l}0400 \\
0800\end{array}$ & $\begin{array}{r}119 \\
76\end{array}$ & $\begin{array}{l}11 \\
11\end{array}$ & $\begin{array}{l}7 \\
7\end{array}$ & $\begin{array}{l}9 \\
9\end{array}$ \\
\hline & Average June & $126^{\circ}$ & 9.4 & 3.9 & 7.0 \\
\hline
\end{tabular}


TAI3LL: SIII

Carbon Mlonoxide Concentration (ppm) for July 1976

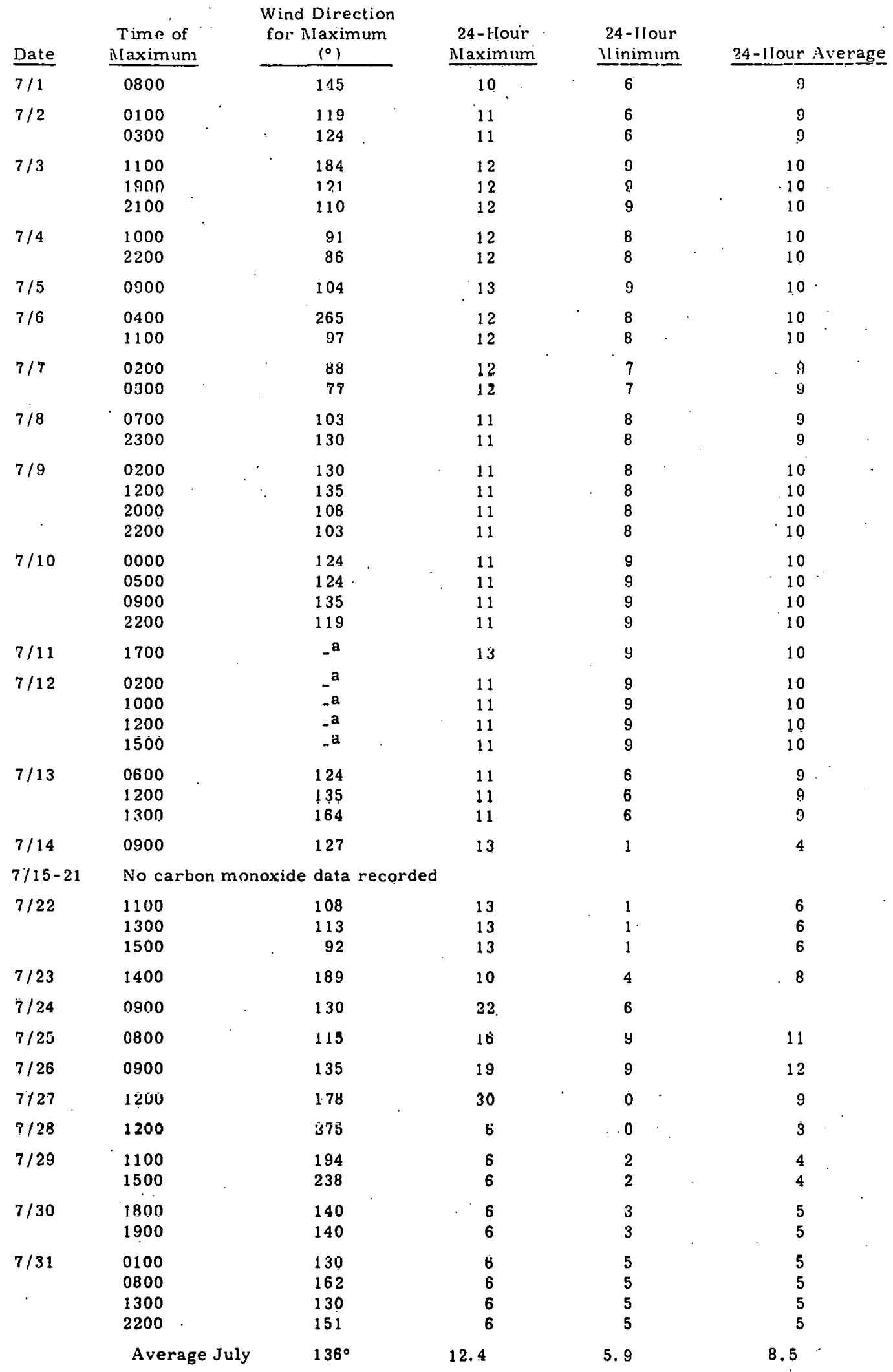

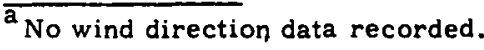




\section{TABLE XIII}

Carbon Monoxide Concentration (ppm) for August 1976

\begin{tabular}{|c|c|c|c|c|c|}
\hline Date & $\begin{array}{c}\text { Time of } \\
\text { Maximum }\end{array}$ & $\begin{array}{l}\text { Wind Direction } \\
\text { for Maximum } \\
\left(^{\circ}\right) \\
\end{array}$ & $\begin{array}{l}\text { 24-Hour } \\
\text { Maximum }\end{array}$ & $\begin{array}{c}\text { 24-Hour } \\
\text { Minim:um } \\
\end{array}$ & 24-Hour Average \\
\hline $8 / 1$ & $\begin{array}{l}1900 \\
2100\end{array}$ & $\begin{array}{l}56 \\
61\end{array}$ & $\begin{array}{l}7 \\
7\end{array}$ & $\begin{array}{l}5 \\
5\end{array}$ & $\begin{array}{l}6 \\
6\end{array}$ \\
\hline $8 / 2$ & 1900 & 351 & 19 & 10 & 15 \\
\hline $8 / 3-24$ & \multicolumn{5}{|c|}{ Carbon monoxide detector not operating; water in system } \\
\hline $8 / 25$ & $\begin{array}{l}0800 \\
0900\end{array}$ & $\begin{array}{r}97 \\
113\end{array}$ & $\begin{array}{l}11 \\
11\end{array}$ & $\begin{array}{l}7 \\
7\end{array}$ & $\begin{array}{l}9 \\
9\end{array}$ \\
\hline $8 / 26$ & 1000 & 146 & 12 & 6 & 8 \\
\hline $8 / 27$ & 1100 & 173 & 11 & 5 & 8 \\
\hline $8 / 28$ & 0800 & 2 & 11 & 8 & 9 \\
\hline $8 / 29$ & $\begin{array}{l}1000 \\
1100 \\
1200 \\
1300 \\
2100 \\
2200\end{array}$ & $\begin{array}{r}104 \\
151 \\
324 \\
126 \\
86 \\
\quad 113\end{array}$ & $\begin{array}{l}10 \\
10 \\
10 \\
10 \\
10 \\
10\end{array}$ & $\begin{array}{l}8 \\
8 \\
8 \\
8 \\
8 \\
8\end{array}$ & $\begin{array}{l}9 \\
9 \\
9 \\
9 \\
9 \\
9\end{array}$ \\
\hline $8 / 30$ & 1200 & 61 & 11 & 9 & 9 \\
\hline $8 / 31$ & $\begin{array}{l}1000 \\
1100 \\
2200\end{array}$ & $\begin{array}{rr}\therefore \quad 167 \\
\therefore \quad & 189\end{array}$ & $\begin{array}{l}10 \\
10 \\
10\end{array}$ & $\begin{array}{l}7 \\
7 \\
7\end{array}$ & $\begin{array}{l}9 \\
9 \\
9\end{array}$ \\
\hline & Average & ust $132^{\circ}$ & 10.6 & 7.3 & 8.9 \\
\hline
\end{tabular}


TABLE XIV

Carbon MIonoxide Concentration (ppm) for September 1976

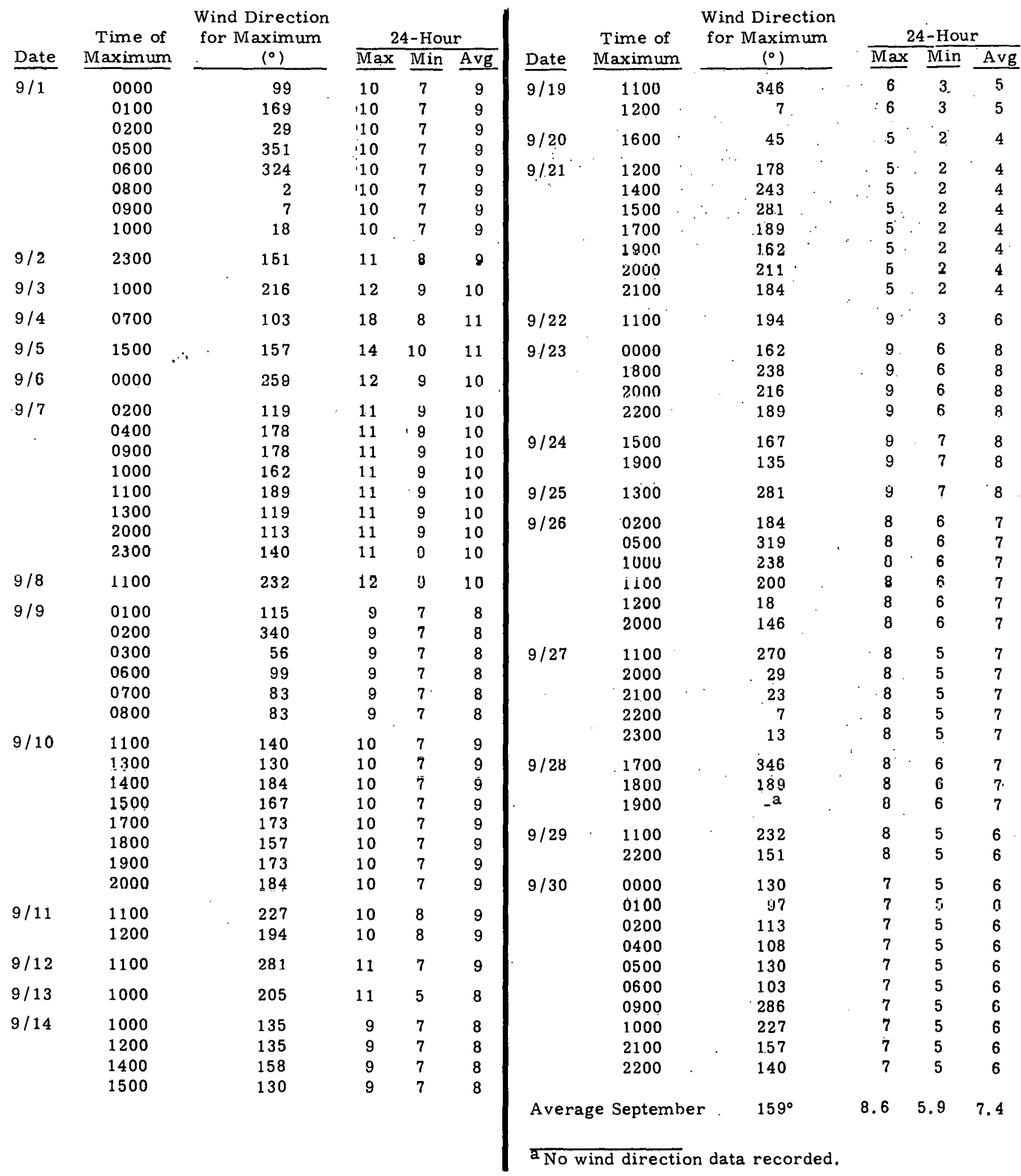


IN131.1: XV

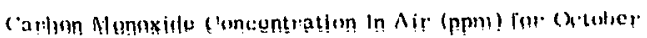

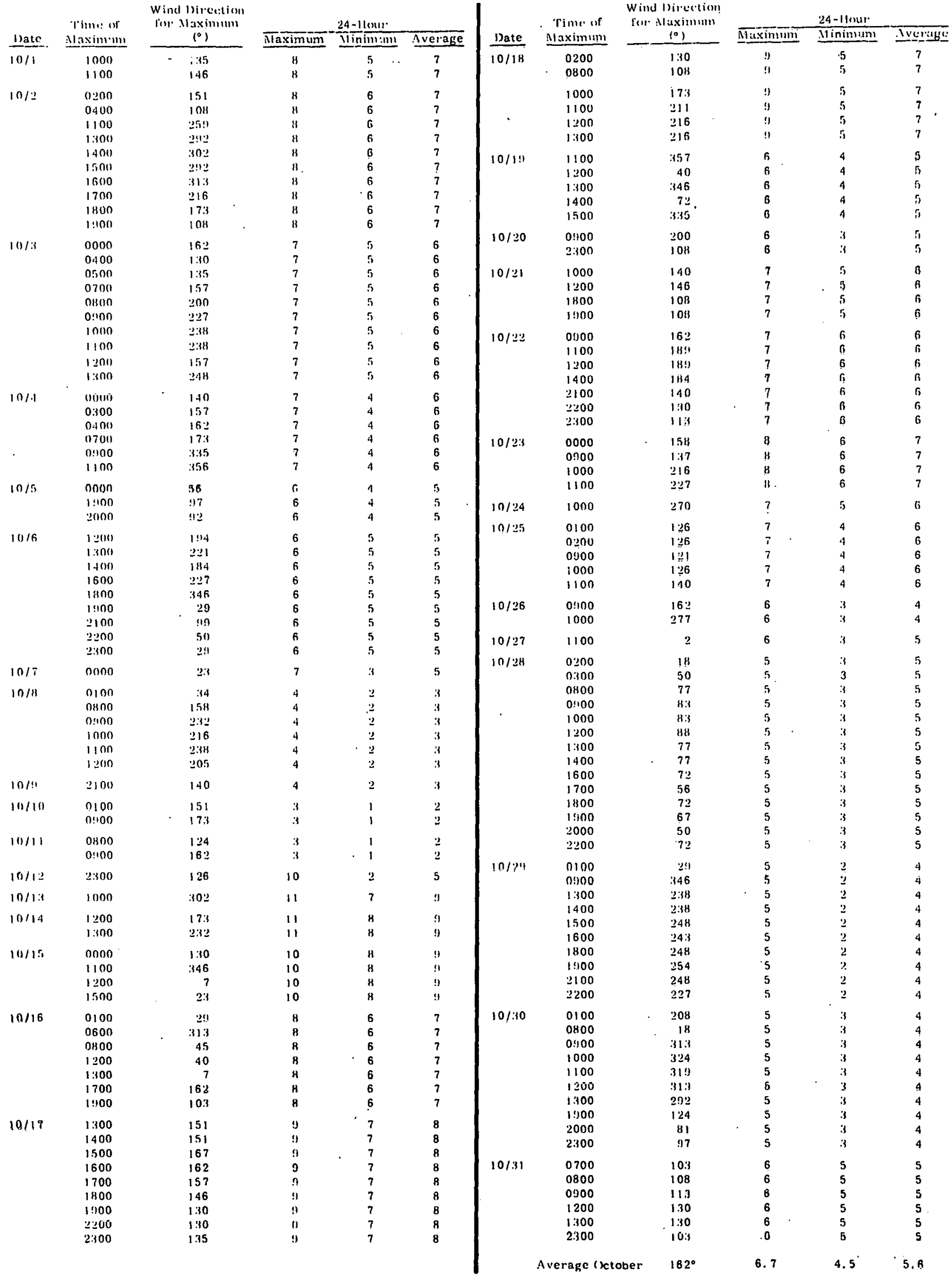


TA|B|,1: XVI

(arton Monoxide Cincentration (ppm) for Nowem'se. 1 !)76

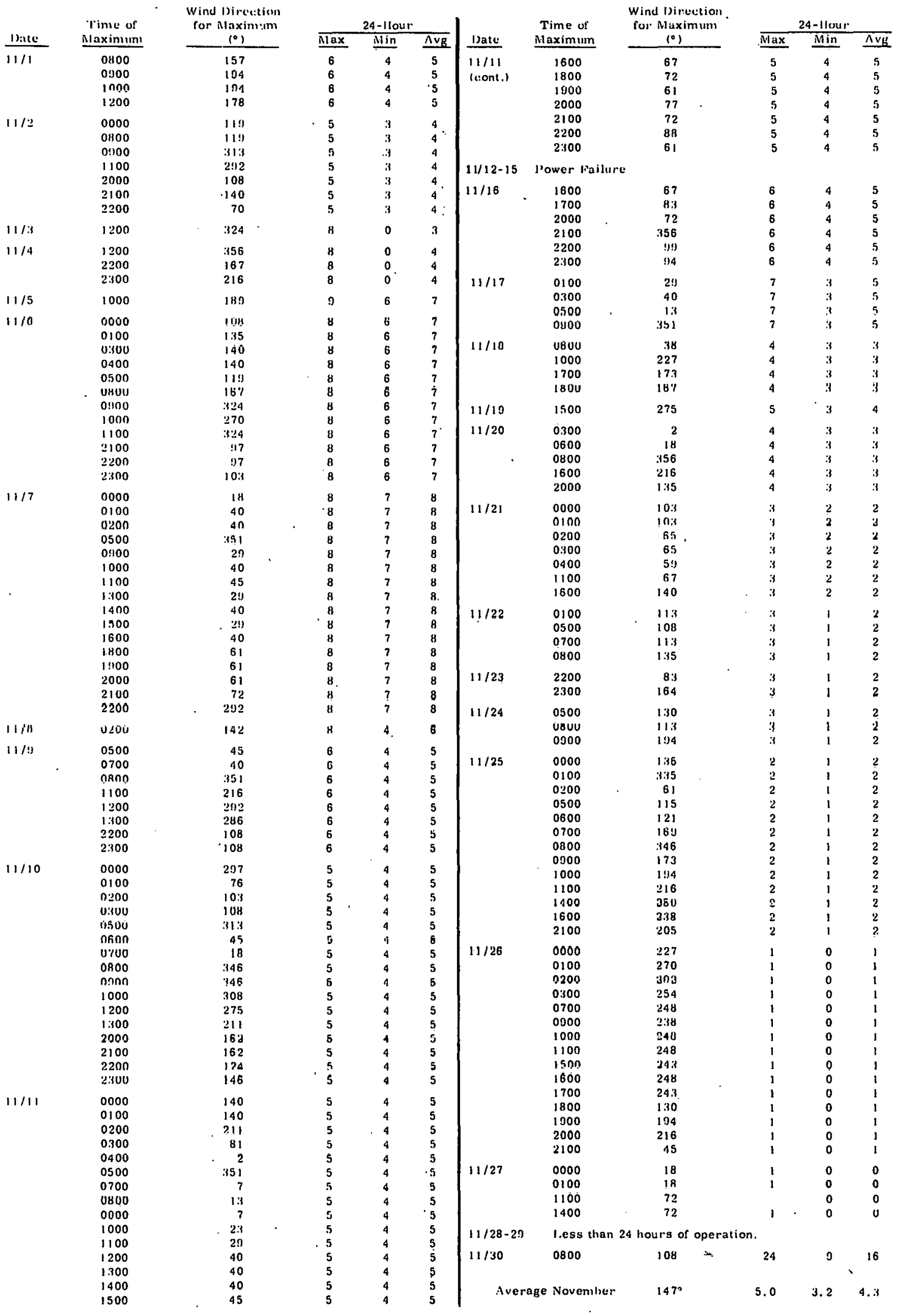


TAISL.F: XVII

Carbon Monoxide Concentration (ppm) for December 1976

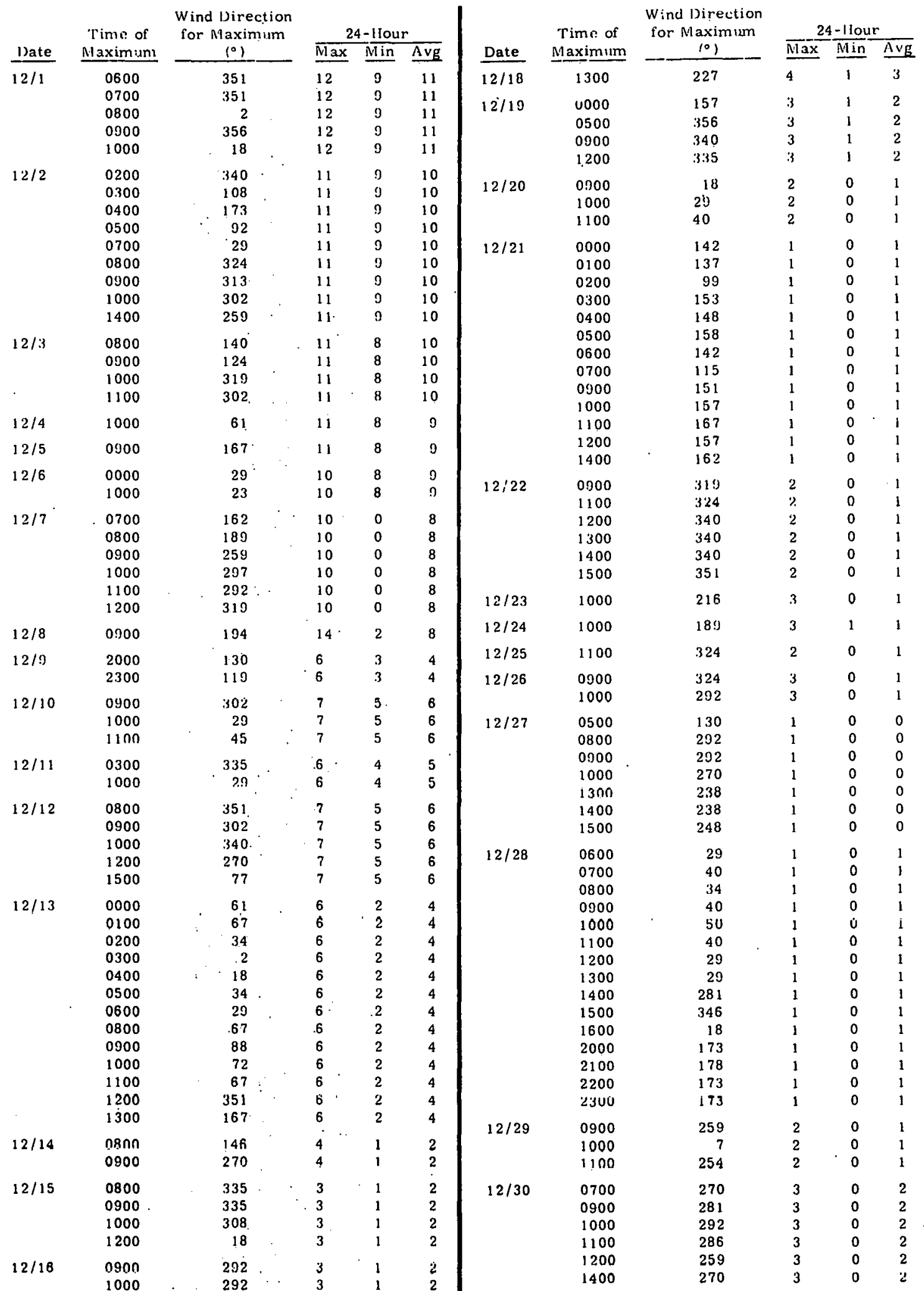

$\begin{array}{llllllll}12 / 17 & 0800 & 67 & 3 & 1 & 2 & 12 / 31\end{array}$

No carbon monoxide data recorded.

$\begin{array}{lllll}\text { Average December } \quad 188^{\circ} & 4.8 & 2.3 & 3.8\end{array}$ 


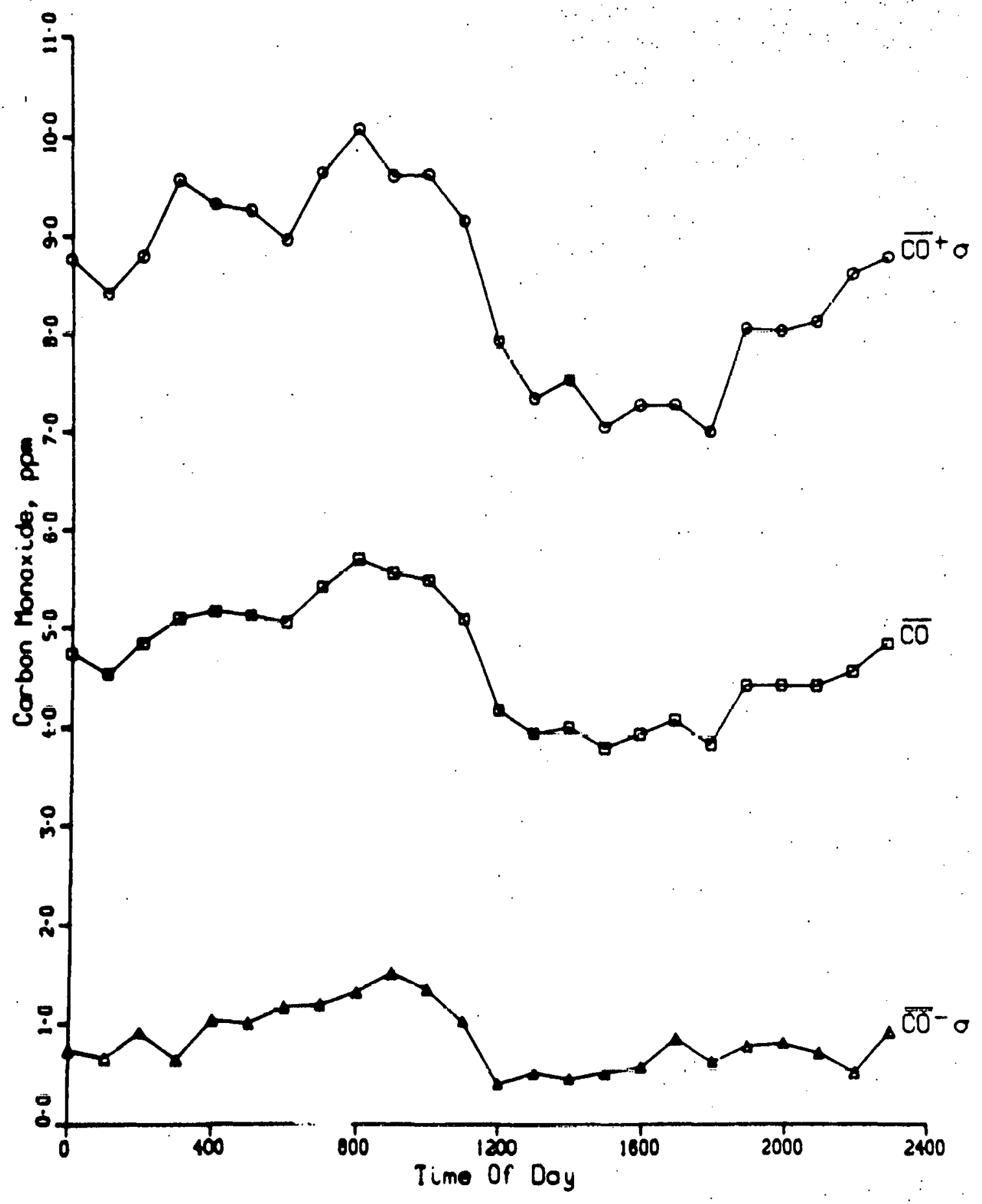

Figure 26. Diurnal Variation in Carbon Monoxide, June 1976 


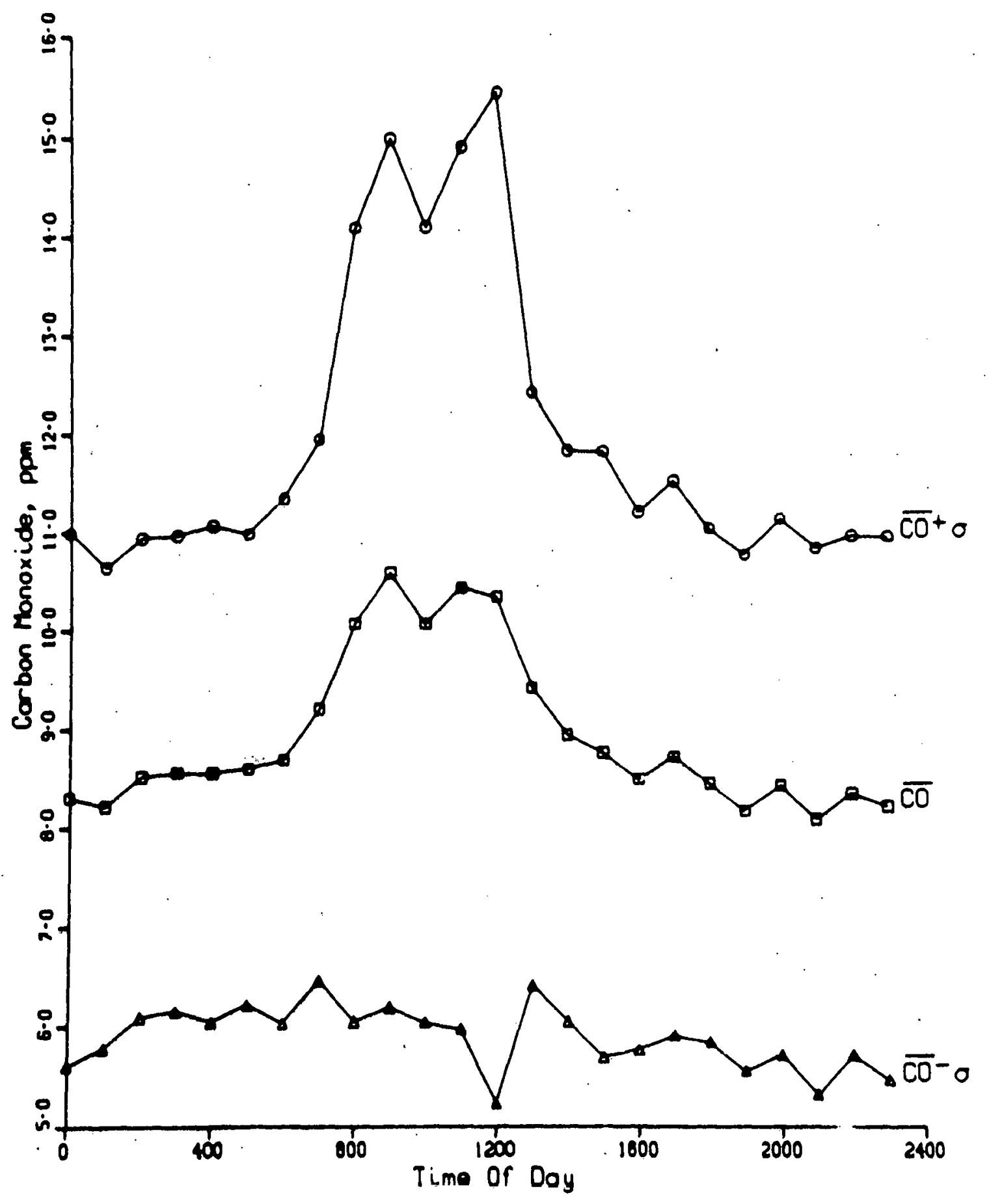

Figure 27. Diurnal Variation in Carbon Monoxide, July 1976 


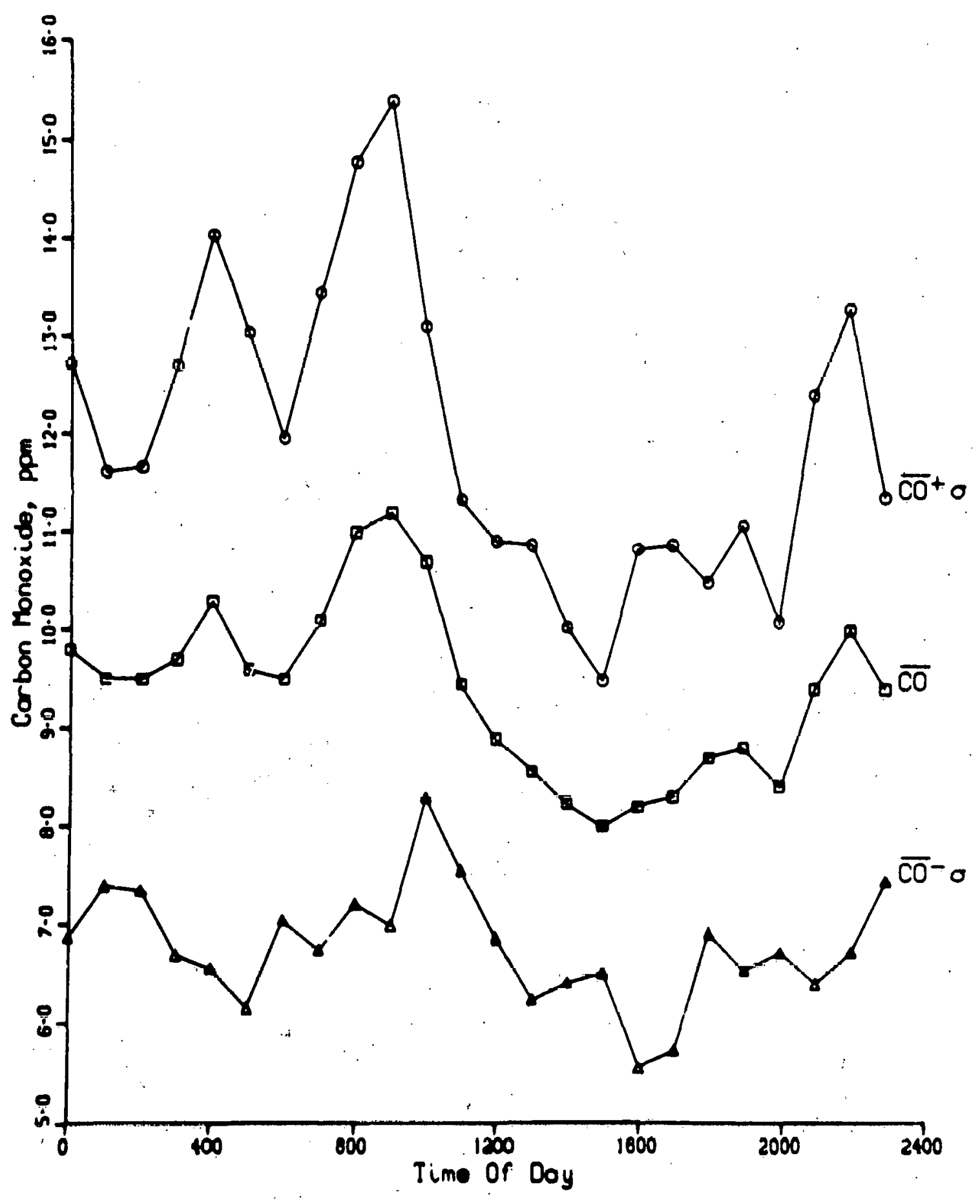

Figure 28. Diurnal Variation in Carbon Monoxide, August 1976 


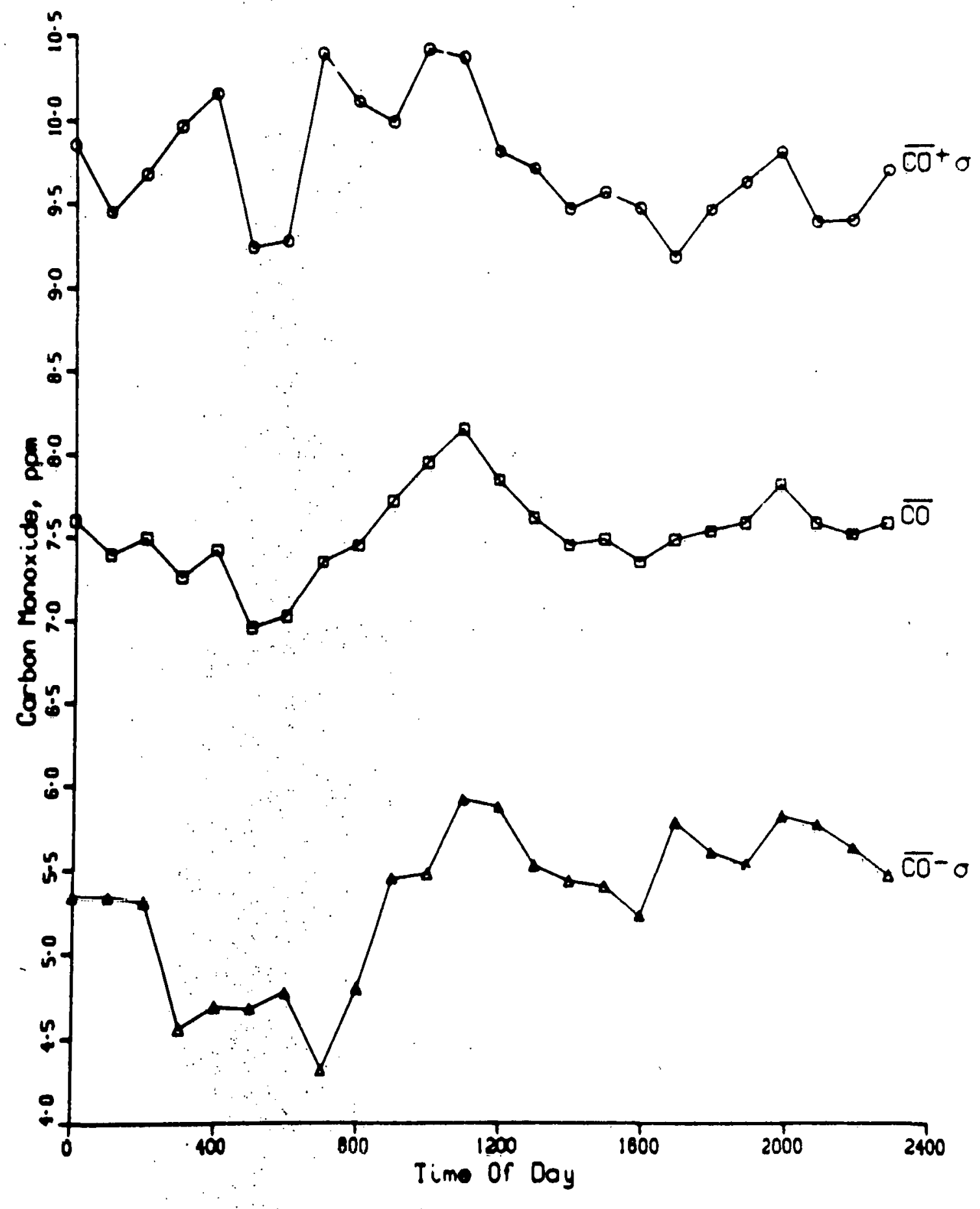

Figure 29. Diurnal Variation in Carbon Morioxide, September 1976 


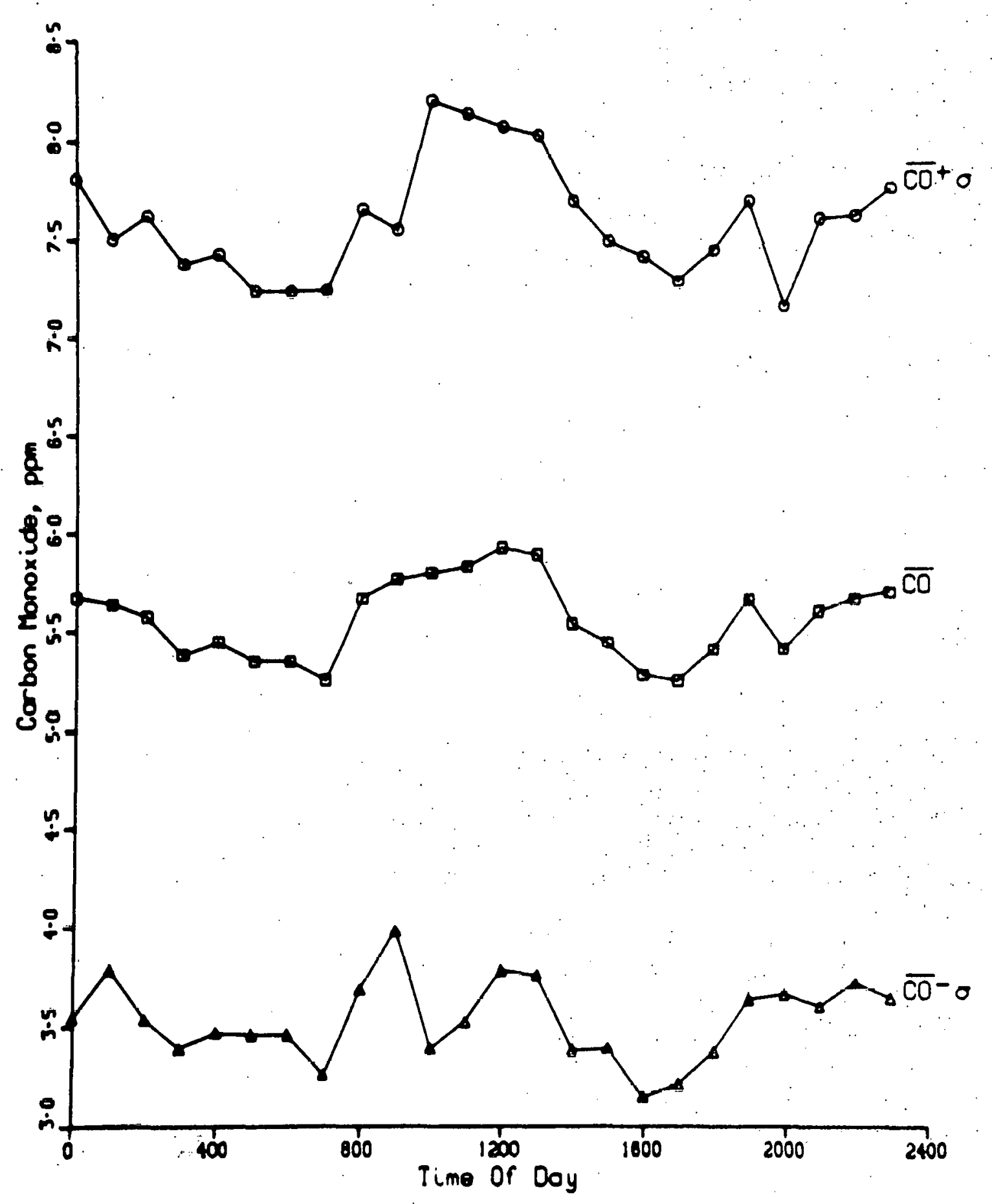

Figure 30. Diurnal Variation in Carbon Monoxide, October 1976 


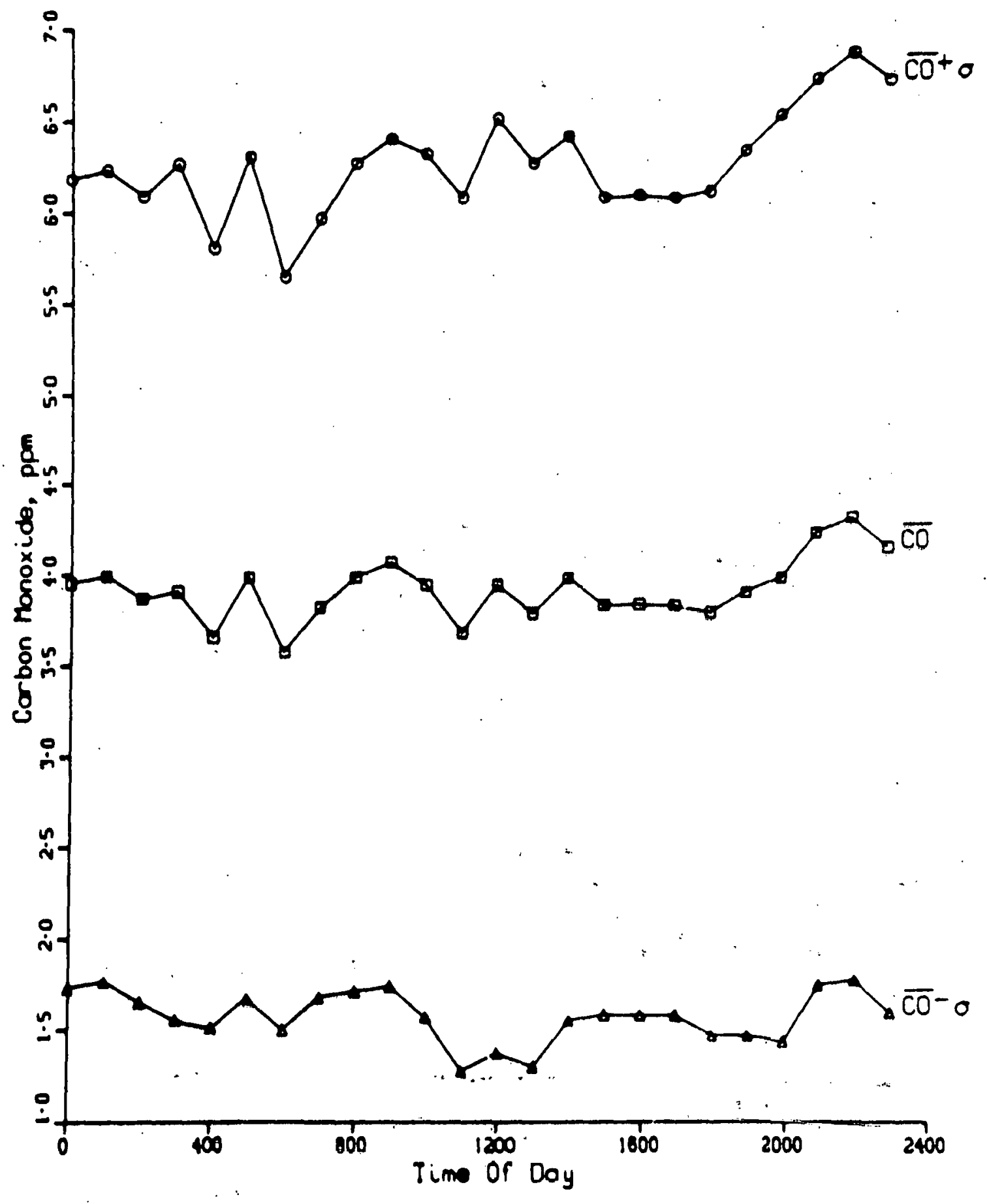

Figure 31. Diurnal Variation in Carbon Monoxide, November 1976 


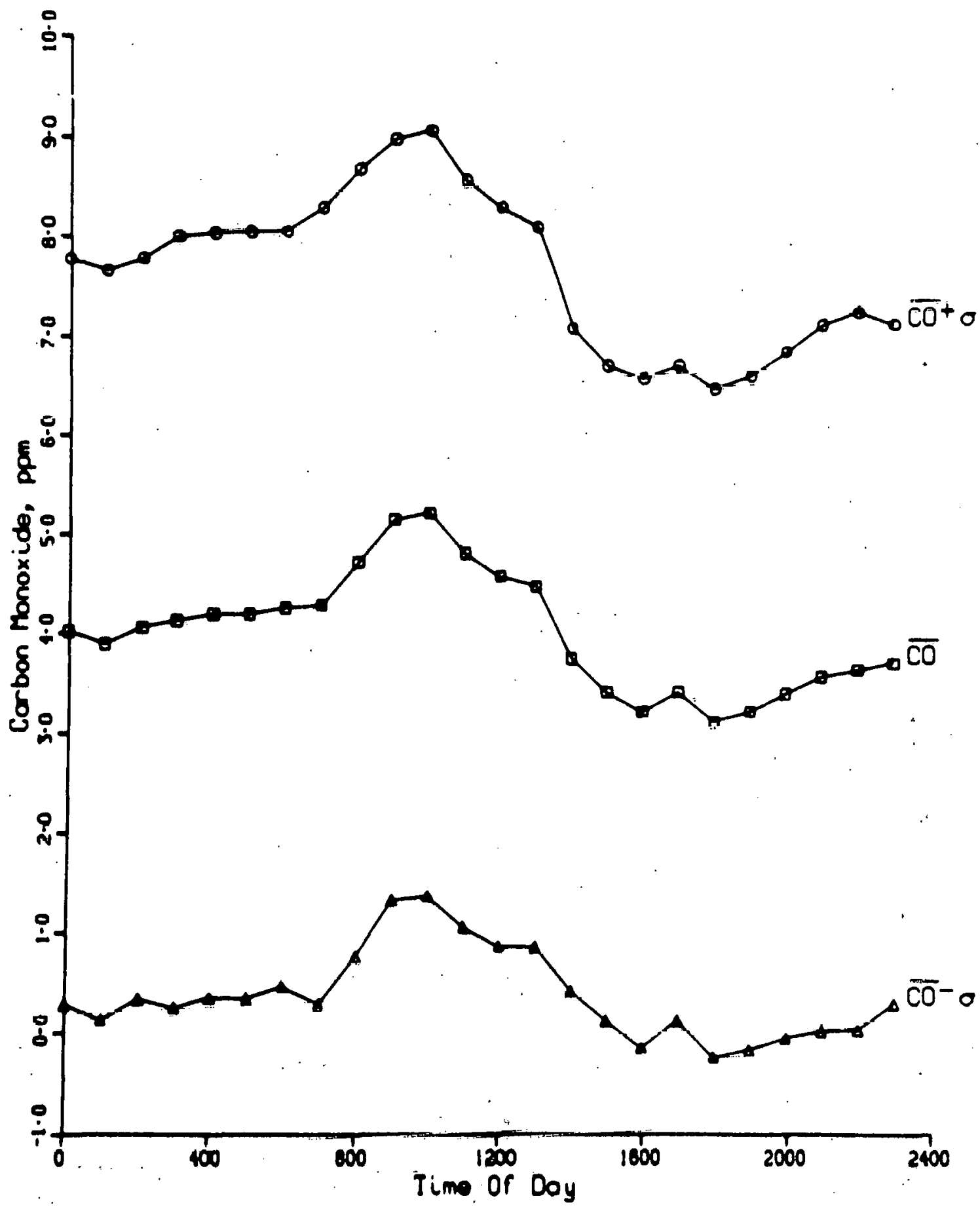

Figure 32. Diurnal Variation in Caŗbon Monoxide, December 1976 


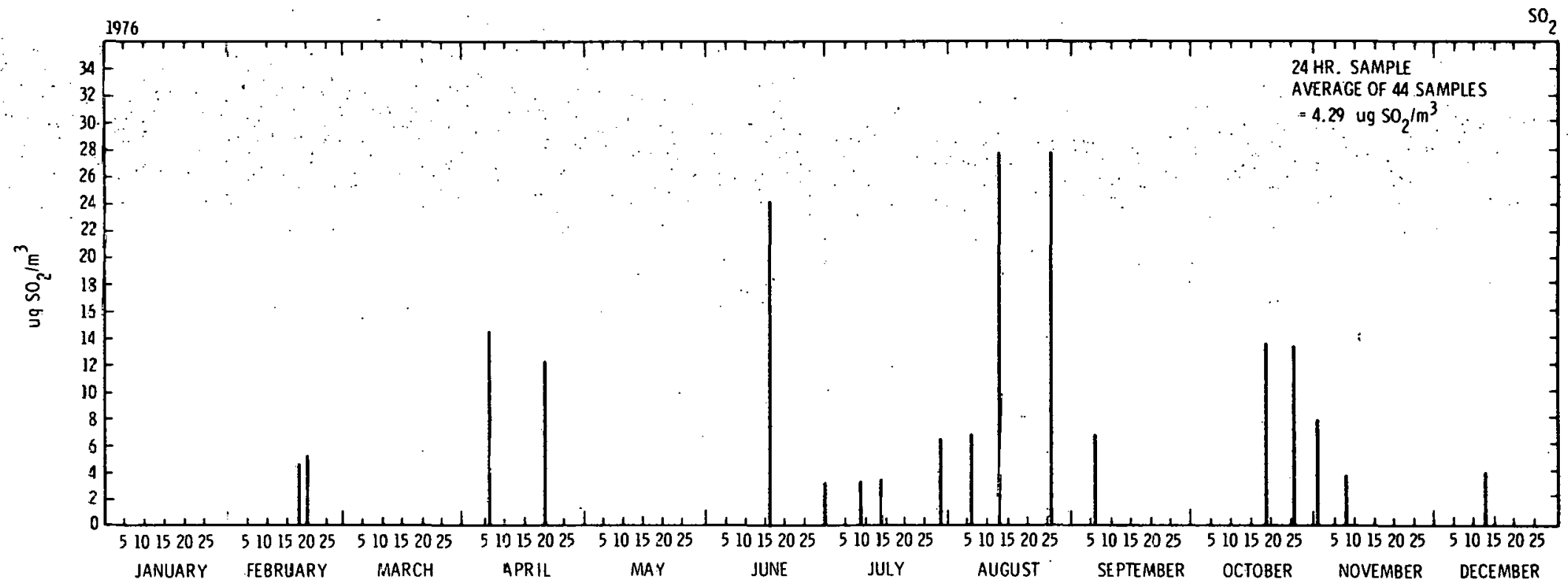

Figure 33. Sulfur Dioxide Concentrations in Air at WIPP Site - CY 1976 


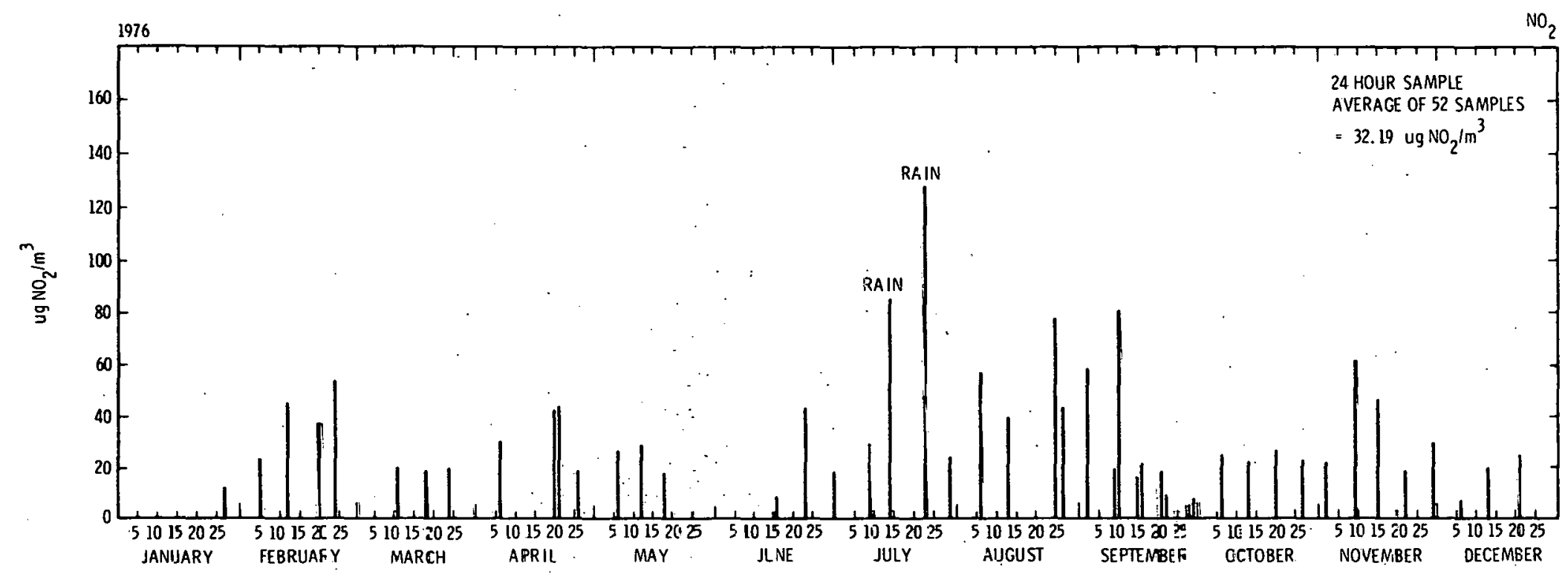

Figure 34. Nitrogen Dioxide Concentrations in Air at WIPP Site - CY 1976 


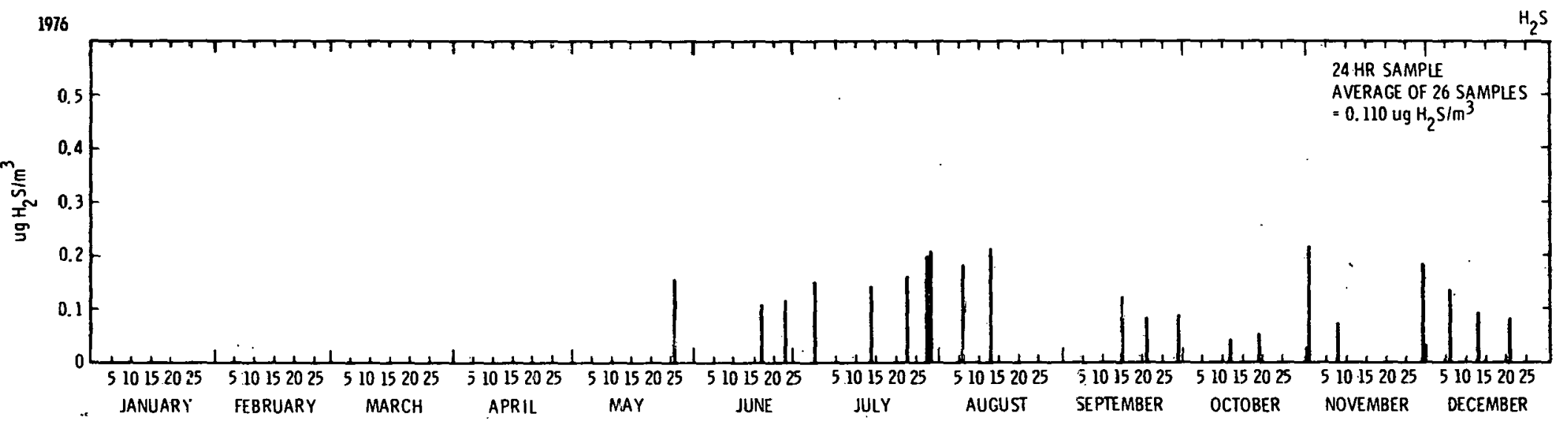

Figure 35. Hydrogen Sulfide Concentrations in Air at WIPP Site - CY 1976 
TABLE XVIII

Elemental Composition of Total Particulate Samples at WIPP Site - CY 1976

\begin{tabular}{|c|c|c|c|c|c|c|c|c|c|c|c|c|c|}
\hline Eate & Type & Log No. & $\begin{array}{c}\text { Volure } \\
\text { Sampled } \\
\left(\mathrm{m}^{3}\right)\end{array}$ & $\begin{array}{l}\text { Weight } \\
\text { Part. } \\
\left(\mathrm{ug} / \mathrm{m}^{3}\right)\end{array}$ & $\begin{array}{l}\text { Sodium } \\
\left.\operatorname{lng} / \mathrm{n}^{3}\right)\end{array}$ & $\begin{array}{c}\text { Potessium } \\
\left(1-\mathrm{g} / \mathrm{m}^{3}\right)\end{array}$ & $\begin{array}{l}\text { Calcium } \\
\left(\mathrm{mg} / \mathrm{m}^{3}\right)\end{array}$ & $\begin{array}{c}\text { Magnesium } \\
\left(\mathrm{mg} / \mathrm{m}^{3}\right)\end{array}$ & $\begin{array}{l}\text { Silleon } \\
\left(4 g^{3} \pi^{3}\right)\end{array}$ & $\begin{array}{c}\text { Iron } \\
\left(\mu \mathrm{g} / \mathrm{m}^{3}\right)\end{array}$ & $\begin{array}{c}\text { Aluminum } \\
\left(\mu \mathrm{s} / \mathrm{m}^{3}\right)\end{array}$ & $\begin{array}{l}\text { Chloride } \\
\text { (Epm) }\end{array}$ & $\begin{array}{c}\text { Sulfate } \\
\text { (ppm) }\end{array}$ \\
\hline $01 / 06 / 76$ & G & 760180 & 754 & 17.0 & 0.0 & 0.0 & 0.0 & 0.0 & & & & 8 & 2 \\
\hline $01 / 15 / 76$ & G & 760410 & 754 & 26.1 & 0.097 & 0.297 & 0.0 & 0.0 & & & & 58 & 1 \\
\hline $01 / 20 / 76$ & G & .760411 & 754 & 17.1 & 0.044 & 0.0 & 0.0 & 0.0 & & & ( & 26 & 2 \\
\hline $01 / 27 / 76$ & G & 760412 & 754 & 8.0 & 0.0 & 0.0 & 0.0 & 0.0 & & & & 3 & 0 \\
\hline $02 / 04 / 76$ & G & 760478 & 754 & 3.6 & 0.365 & 0.0 & 0.0 & 0.053 & & & & 0 & 20 \\
\hline $02 / 10 / 76$ & G & 760577 & 754 & 7.6 & 0.517 & 0.255 & 0.0 & 0.269 & & . & & & 12 \\
\hline $02 / 17 / 76$ & G & 760593 & 754 & 33.7 & 0.015 & 0.141 & 0.0 & 0.252 & & & & 10 & 9 \\
\hline $02 / 10 / 76$ & G & 760677 & 754 & 30.5 & & & & & & & & 0 & 3.9 \\
\hline $02 / 23 / 76$ & $G$ & 760678 & 754 & 10.6 & & & & & & & & 0 & 19 \\
\hline $03 / 03 / 76$ & $G$ & 760753 & 754 & & & & & & & & & 5 & 32 \\
\hline $03 / 03 / 76$ & G & 761089 & 754 & 11.7 & 0.729 & 0.0 & 0.0 & 0.305 & & & & 0 & 60 \\
\hline $03 / 11 / 76$ & G & 761090 & 754 & $\approx 8.4$ & 1.127 & $-3 . C 82$ & 0.0 & 1.101 & : & & & 0 & 66 \\
\hline $03 / 15 / 76$ & G & 761091 & 754 & 58.9 & $1.12 \%$ & 0.023 & 0.013 & 1.233 & & & & 2.5 & 210 \\
\hline $03 / 16 / 76$ & G & 761092 & 754 & 18.3 & 1.061 & 0.0 & 0.0 & 0.869 & & & & 0 & .73 \\
\hline $03 / 17 / 76$ & G & 761093 & 754 & 25.5 & 1.194 & 0.019 & 0.0 & 0.902 & & & & 2.5 & 68 \\
\hline $03 / 23 / 76$ & W & 7ó1025 & 566 & & & & & & & & & 0 & 17 \\
\hline $03 / 2 \equiv / 76$ & G & 761023 & 754 & & & & & & & & & 2.5 & 41 \\
\hline $03 / 30 / 76$ & W & 761.024 & $75 \div$ & & & & & & & & & 5 & 22 \\
\hline $04 / 06 / 76$ & W & 761026 & 566 & & & & & & & & & 5 & 18 \\
\hline $04 / 12 / 76$ & G & 761085 & 754 & 7.3 & 0.729 & C. 0 & 0.0 & 0.259 & & & & 0 & 72 \\
\hline $04 / 23 / 76$ & G & 761086 & 754 & 3.2 & 1.658 & e.o & 0.0 & 0.703 & & & & 0 & 10.5 \\
\hline $04 / 14 / 76$ & W & 761097 & 754 & 1.2 & .0 .099 & a.o & 0.0 & 0.259 & & & & 2.5 & 32 \\
\hline $\mathrm{CL} / 18 / 70^{\circ}$ & oj & 751 15s & 754 & 16.4 & 0.332 & 0.005 & 0.0 & 0.869 & & & . & 22.5 & 69 \\
\hline $04 / 19 / 76$ & G & 75106 & 754 & 30.1 & 0.597 & 0.0 & 0.0 & 0.869 & & & & 2.5 & 64 \\
\hline $01 / 20 / 76$ & $1 F$ & 761117 & 754 & & 0.048 & 0.0 & 0.0 & 0.0 & & & & 0 & 40 \\
\hline $04 / 25 / 76$ & G & 761118 & 754 & 26.4 & 0.663 & 0.0 & 0.0 & .0 .570 & . & . & & 0 & 49 \\
\hline $05 / 03 / 76$ & $\mathrm{G}$ & 761270 & 754 & 6.5 & 0.796 & 0.0 & 0.0 & 0.537 & & & & 0 & 38 \\
\hline $05 / 01+76$ & G & $7612 \div 1$ & $75 \div$ & 8.1 & $0: 398$ & 00 & 0.0 & 0.225 & & & & 2.5 & 50 \\
\hline $05 / 05 / 76$ & v & 761272 & 754 & & 0.042 & 0.0 & 0.0 & 0.0 & & & & 15 & 13 \\
\hline $05 / 20 / 76$ & C & $761+35$ & 754 & 0.8 & 1.127 & 0.0 & 0.0 & 0.636 & & & & 2.5 & 53 \\
\hline $05 / 11 / 76$ & $G$ & $762+36$ & 754 & 8.8 & 0.663 & G.0 & 0.0 & 0.471 & & & & 0 & 39 \\
\hline $05 / 17 / 76$ & G & 761438 & 754 & 15.1 & 0.497 & 0.0 & C.o & 0.537 & & & & 0 & 65 \\
\hline $05 / 18 / 76$ & G & 761439 & 754 & .13 .4 & 0.729 & 0.0 & 0.0 & 0.537 & & & & 0 & 63 \\
\hline $05 / 19 / 76$ & W & 761437 & 754 & & 0.0 & 0.2 & 0.0 & 0.0 & & & & 0 & 46 \\
\hline
\end{tabular}


TABLE XVIII (cont)

\begin{tabular}{|c|c|c|c|c|c|c|c|c|c|c|c|c|c|}
\hline Date & Type & LCg No. & $\begin{array}{l}\text { Volume } \\
\text { Sampled } \\
\therefore\left(\mathrm{n}^{3}\right)\end{array}$ & 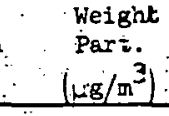 & $\begin{array}{l}\text { Sodium } \\
\left(\mathrm{mg} / \mathrm{m}^{3}\right)\end{array}$ & $\begin{array}{l}\text { Potassium } \\
\therefore\left(\mu \mathrm{g} / \mathrm{m}^{3}\right) \\
\end{array}$ & $\begin{array}{l}\text { Calcium } \\
\left(\mathrm{ng} / \mathrm{n}^{3}\right)\end{array}$ & $\begin{array}{c}\text { Magnesium } \\
\left(\mu g, \mathrm{~m}^{3}\right)\end{array}$ & $\begin{array}{l}\text { silicon } \\
\left|\mathrm{\mu g} / \mathrm{m}^{3}\right|\end{array}$ & $\begin{array}{c}\text { Iron } \\
\left(\mu \mathrm{g} / \mathrm{m}^{3}\right)\end{array}$ & $\begin{array}{l}\text { Aluminum } \\
\left(\mu g / m^{3}\right)\end{array}$ & $\begin{array}{l}\text { Chloride } \\
\text { (pon })\end{array}$ & $\begin{array}{c}\text { Sulfate } \\
\text { lopes }\end{array}$ \\
\hline $05 / 12 / 76$ & W. & 761476 & 754 & $\therefore$ & 0.0 . & 0.034 & 0.069 & $0: 228$ & & $\therefore$ & t & 5 & 22 \\
\hline $05 / 24 / 76$ & $G$ & 701477 & 754 & $16 .:$ & 0.0 & 0.0 & 0.0 & 0.040 & & & & 0 & 48 \\
\hline $05 / 25 / 76$ & $G$ & 761478 & 754 & 49.9 & 0.0 & 0.023 & 0.0 & 0.471 & & & & 0 & 69 \\
\hline$c 5 / 26 / 76$ & W & 761479 & .754 & & 0.0 & 0.001 & 0.034 & 0.0 & & & & 0 & 0 \\
\hline $06 / 01 / 76$ & $G$ & 762480 & 754 & 15.4 & 0.0 & $0: 0$ & 0.0 & 0.0 & & & & 0 & 69 \\
\hline $06 / 02 / 76$ & G & 751481 & 754 & ניט & 0.0 & 0.0 & 0.0 & 0.0 & & & & 0 & 52 \\
\hline $06 / 03 / 7 \epsilon$ & W & 751432 & 754 & & 0.0 & 0.002 & 0.101 & 0.042 & & & & 0 & 44 \\
\hline $06 / 14 / 7 \varepsilon$ & G & 761558 & 754 & 30.2 & $4: 310$ & 0.049 & 0.0 & 0.915 & 0.398 & 0.174 & & 10 & 40 \\
\hline Có/15/76 & G & $76 i 559$ & 754 & 77.7 & 4.380 & 0.036 & 0.0 & 1.459 & 0.0 & 0.724 & & 0 & 33 \\
\hline $06 / 16 / 76$ & N & 761560 & 754 & & 0.074 & 0.008 & 0.300 & 0.218 & & 0.219 & & 0 & 17 \\
\hline $06 / 2 i, 76$ & G & 761561 & 754 & 21.6 & 4.045 & 0.0 & 0.0 & 0.646 & & 0.107 & & 0 & 47 \\
\hline $06 / 22 / 75$ & G & 761562 & 754 & 29.4 & 3.382 & 0.0 & 0.0 & 0.516 & & 0.107 & & 0 & 39 \\
\hline $06 / 23 / 76$ & $\mathrm{~W}$ & $T 61563$ & 754 & & 0.089 & 0.016 & 0.473 & 0.406 & & 0.537 & & 0 & 21 \\
\hline $05 / 28 / 75$ & G & 761536 & 1414 & 11.5 & 1.909 & 0.0 & 0.0 & 0.050 & 0.0 & 0.043 & & 0 & 39 \\
\hline $00 / 30 / 75$ & W & 761587 & 754 & $12 . .3$ & 3.183 & 0.042 & 0.658 & 1.081 & 0.332 & 0.146 & & 0 & 25 \\
\hline $07 / 01 / 75$ & G & 761588 & 754 & & 0.0 & 0.0 & 0.172 & 0.0 & & 0.154 & & 0 & 18 \\
\hline$c 7 / 06 / 75$ & G & 761040 & $75+$ & 23.3 & 2.321 & 0.020 & 0.0 & 0.431 & 0.0 & 0.008 & & 0 & 45 \\
\hline $07 / 07 / 76$ & $\epsilon$ & $76 ́ 1641$ & 754 & 7.7 & $2 . \overline{42}$ & 0.0 & 0.0 & 0.190 & 0.0 & 0.0 & & 0 & 20 \\
\hline $07 / 08 / 70$ & $n^{\prime}$ & ?ó: 1642 & 623 & & 0.107 & 0.005 & 0.083 & 0.049 & 0.0 & 0.0 & & 0 & \\
\hline $07 / 12 / 70$ & c & 7061069 & 754 & 3.5 & 0.0 & 0.093 & 0.0 & & 0.0 & 0.0 & 0.166 & 0 & 42 \\
\hline $07 / 13 / 76$ & G & 761670 & 754 & 7.3 & 0.0 & 0.023 & 0.0 & & 0.0 & & 0.166 & 0 & 54 \\
\hline $07 / 14 ; 6$ & $\because$ & 761671 & 566 & & 0.0 & 0.018 & 0.046 & 0.023 & 0.0 & 0.053 & & 0 & 41 \\
\hline $07 / 19 / \% 0$ & G & 761783 & 754 & & 0.0 & 0.126 & & 0.0 & 0.0 & 0.048 & 0.265 & 0 & 51 \\
\hline $07 / 20 / 76$ & $G$ & 761784 & 754 & & 0.0 & 0.102 & 0.0 & 0.0 & 0.0 & 0.0 & 0.265 & 0 & 48 \\
\hline $07 / 2=/ 76$ & $y$ & 701705 & 754 & & 0.0 & 0.044 & 0.218 & 0.057 & 3.32 & 0.135 & 0.130 & 0 & 28 \\
\hline $07 / 25 / 76$ & G & $761916 ́$ & 754 & $1: 0$ & 0.0 & 0.045 & 0.0 & & & 0.034 & 0.130 & & \\
\hline $07 / 27 / 70$ & G & 761917 & $75 \div$ & 9.0 & 0.0 & 0.038 & 0.0 & & & 0.0 & 0.230 & & 25 \\
\hline$c 7 / 29 / 76$ & $N$ & 761918 & 754 & 34.1 & & 0.113 & 0.210 & 0.053 & & 0.106 & 0.053 & & \\
\hline $03 / 03 / 76$ & G & 761019 & 754 & 7.9 & 0.0 & 0.357 & & 0.0 & 0.365 & & 0.318 & 0 & 49 \\
\hline $08 / 04 / 76$ & $G$ & 761920 & 754 & 125 & 0.0 & 0.060 & 0.0 & & 0.0 & & 0.166 & 0 & 50 \\
\hline $03 / 0=170$ & W & 761921 & 754 & 37.5 & 0.008 & 0.094 & 0.586 & 0.052 & & 0.066 & & & 85 \\
\hline $08 / 09176$ & G & 761964 & 754 & 11.5 & 0.0 & 0.111 & 0.0 & 0.0 & 0.365 & & 0.265 & & 39 \\
\hline $28 /$ เง; 76 & G & 761965 & 754 & 12.9 & 0.0 & 0.033 & 0.0 & & & 0.0 & 0.077 & & \\
\hline $08 / 17 ; 76$ & $v$ & 761960 & 754 & $\Xi 8.7$ & 0.0 & 0.061 & 0.633 & 0.034 & & 0.032 & & & 87 \\
\hline$c 8 / 16$ '76́ & G & 752053 & 754 & 6.4 & 0.424 & 0.0 & 0.0 & 0.0 & & 0.0 & 0.345 & & 35 \\
\hline $08 / 19: 76$ & W & 762055 & 754 & 39.1 & 0.698 & 0.074 & 0.414 & 0.042 & 0.286 & 0.088 & 0.069 & & 145 \\
\hline $\cos / 19: 76$ & & 762054 & 754 & 3.8 & 0.690 & 0.0 & 0.0 & 0.0 & 0.0 & 0.0 & 0.414 & & 51 \\
\hline
\end{tabular}


TABLE XVIII (cont)

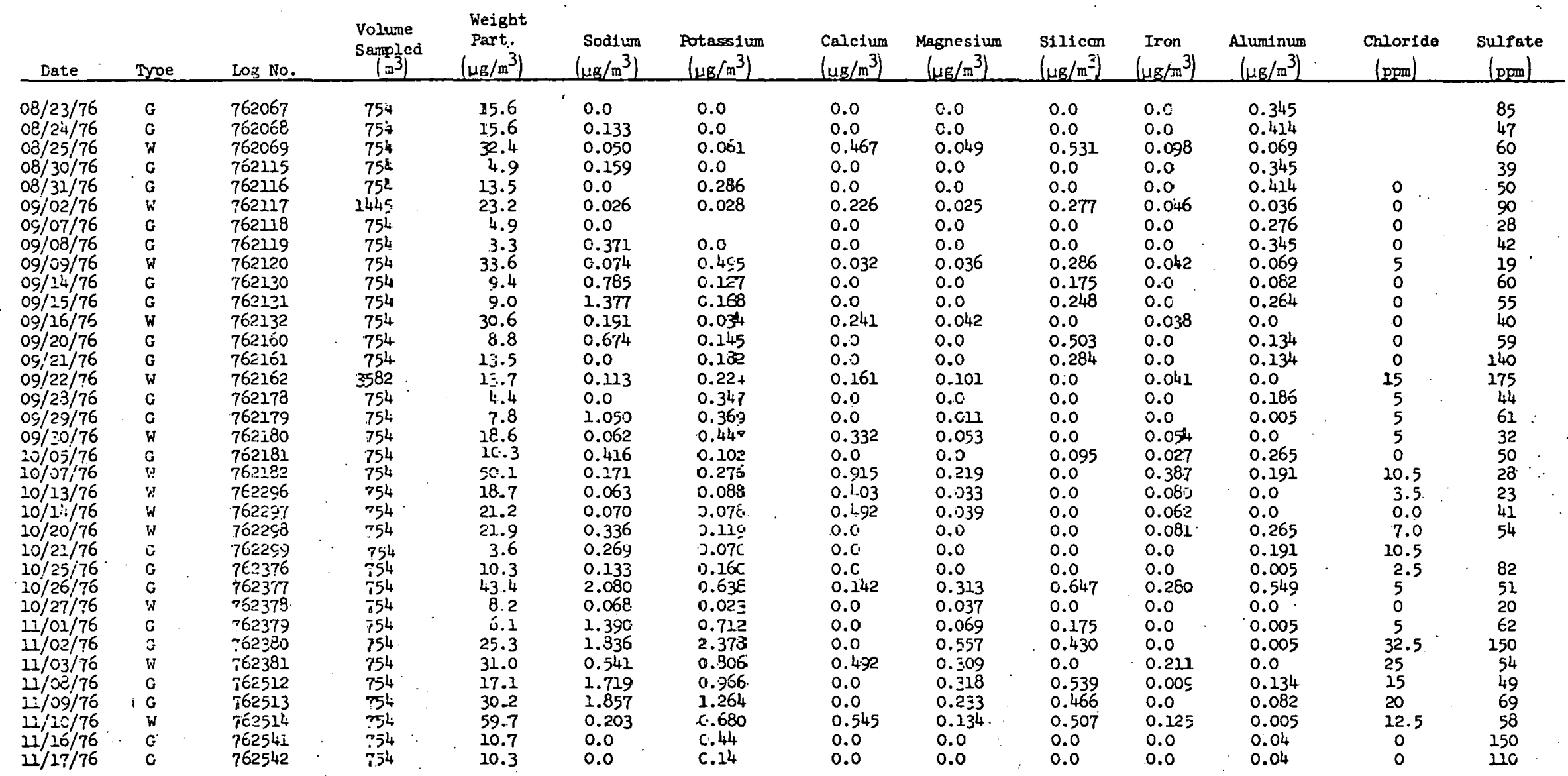


TABLE XVIII (cont)

?

\begin{tabular}{|c|c|c|c|c|c|c|c|c|c|c|c|c|c|}
\hline Date & Ispe & IC.B No. & $\begin{array}{l}\text { Volume } \\
\text { Sampled } \\
\left(m^{3}\right)\end{array}$ & $\begin{array}{l}\text { Weight } \\
\text { Part. } \\
\left(\mu \mathrm{g} / \mathrm{m}^{3}\right)\end{array}$ & $\begin{array}{l}\text { Sodium } \\
\left(\mathrm{ug} / \mathrm{m}^{3}\right)\end{array}$ & $\begin{array}{c}\text { Potassium } \\
\left(\mathrm{\mu g} / \mathrm{m}^{3}\right)\end{array}$ & $\begin{array}{l}\text { Calcium } \\
\left(\mu \mathrm{g} / \mathrm{m}^{3}\right)\end{array}$ & $\begin{array}{c}\text { Magnesium } \\
\left(\mu g^{\prime} \mathrm{m}^{3}\right)\end{array}$ & $\begin{array}{l}\text { silicon } \\
\left(\mathrm{ug}_{\mathrm{m}} \mathrm{m}^{3}\right)\end{array}$ & $\begin{array}{c}\text { Iron } \\
\left(\mu \mathrm{g} / \mathrm{m}^{3}\right)\end{array}$ & $\begin{array}{l}\text { Aluminum } \\
\left(\mathrm{ug} / \mathrm{m}^{3}\right)\end{array}$ & $\begin{array}{c}\text { Chloride } \\
\text { (opn) }\end{array}$ & $\begin{array}{c}\text { Sulfaite } \\
\text { (opm) }\end{array}$ \\
\hline $11 / 18 / 70^{\circ}$ & w & 762543 & 754 & 29.8 & 0.422 & 1.77 & 0.30 & 0.31 & 0.0 & 0.12 & 0.0 & 115 & 68 \\
\hline $\bar{บ} / 19 / 7 \overline{0}$ & G & 762544 & 754 & 8.0 & 0.0 & 0.58 & 0.0 & 0.0 & 0.0 & 0.0 & 0.12 & 10.5 & 60 \\
\hline $11 / 20 / 75$ & G & 762545 & 754 & 18.4 & 0.0 & 2.45 & 0.0 & 0.0 & 0.0 & $0: 0$ & 0.12 & 80.5 & 95 \\
\hline $11 / 21 / 75$ & G & 762546 & 754 & 19.0 & 0.0 & 0.24 & 0.0 & 0.0 & 0.0 & 0.0 & 0.19 & 3.5 & 57 \\
\hline $11 / 22 / \tau_{0}$ & G & 752547 & 754 & 11.1 & 0.0 & 0.02 & 0.0 & 0.0 & 0.0 & 0.0 & 0.19 & 3.5 & 45 \\
\hline $11 / 23 / 76$ & G & 7502548 & 754 & $9 . \overline{5}$ & 0.0 & 0.04 & 0.0 & 0.0 & 0.0 & 0.0 & 0.12 & 0 & 52 \\
\hline $11 / 24 / 76$ & G & 752549 & 754 & $2 i .2$ & 0.0 & 0.15 & 0.0 & 0.0 & 0.0 & 0.0 & 0.19 & 0 & 75 \\
\hline $11 / 28 / 76$ & G & 762576 & 3330 & 25.7 & 0.0 & 0.29 & 0.19 & 0.0 & 0.0 & 0.51 & 0.21 & 14 & $300+$ \\
\hline $11 / 30 / 76$ & G & $76=577$ & 754 & 14.5 & 0.0 & 1.98 & 0.0 & 0.0 & 0.0 & 0.0 & 0.12 & 59.5 & 85 \\
\hline $12 / 01 / 76$ & G & 762.545 & 754 & 15.3 & 0.0 & 0.76 & 0.0 & 0.0 & 0.0 & 0.0 & 0.27 & 21 & 50 \\
\hline $12 / 02 / i^{6}$ & G & $76 \approx 5546$ & 754 & 25.1 & 0.0 & 2.71 & 0.0 & 0.0 & 0.0 & 0.0 & 0.19 & 84 & 125 \\
\hline $12 / 07 / 76$ & G & 762700 & 754 & 11.5 & 0.0 & 0.74 & 0.0 & 0.0 & 0.0 & 0.03 & 0.37 & 16.7 & 42 \\
\hline $12 / 08 / 76$ & G & 762701 & 754 & 11.9 & 0.0 & 0.62 & 0.0 & 0.0 & 0.0 & 0.0 & 0.56 & 36.7 & 40 \\
\hline $12 / 09 / 76$ & W & 762702 & 754 & 13.5 & 0.0 & 0.13 & 0.23 & 0.05 & 0.0 & 0.15 & 0.0 & 3.3 & 43 \\
\hline $12 / 14 / 76$ & G & 762713 & 754 & 18.2 & 0.0 & 0.10 & 0.0 & 0.0 & 0.0 & 0.0 & 0.13 & 10 & 53 \\
\hline $12 / 15 / 76$ & G & 762714 & 754 & 19.0 & 0.0 & 0.81 & 0.0 . & 0.0 & 0.0 & 0.0 & 0.30 & 66.7 & 57 \\
\hline $12 / 16 / 76$ & w & 762715 & 754 & 25.3 & 0.138 & 0.92 & 0.38 & 0.16 & 0.0 & 0.30 & 0.30 & 30 & 29 \\
\hline
\end{tabular}




\section{DISCUSSION}

Water problems plagued the first several months of operation of the carbon monoxide and ozone monitors. In mid-July water began to condense in the sampling lines of the carbon monoxide monitor, necessitating the removal of all lines and air drying before reassembly. In August water again entered the system and reached the infrared detector cell before being noticed. The cell had to be removed, cleaned, dried, and reinstalled. A suitable dryer* was obtained and installed at the inlet to the sampling system, and all water problems were eliminated. In August a definite increase in carbon monoxide levels was noted, and after alignment and calibration it was found that the mechanical zero had changed and was equivalent to a 4-ppm CO level. Therefore, all readings for July, August, and September are probably high by 4 ppm.

Sulfur dioxide concentrations as presented in Figure 33 had an average 24-hour value of $4.29 \mu \mathrm{g} / \mathrm{m}^{3}$. The highest value occurred on August 13, 1976, when it reached $28 \mu \mathrm{g} / \mathrm{m}^{3}$. The sulfur dioxide levels for the year were below Federal and State standard levels (see Appendix D).

Based on 24-hour samples taken once per week, the average 24-hnur ronsentration of nitrogen dioxide during the 1976 sampling period was $32.19 \mu \mathrm{g} / \mathrm{m}^{3}$. The hlghest value was $130 \mu \mathrm{g} / \mathrm{m}^{3}$, from a sample collected during a i.dinstorm on July 23, 1076 (Figure 34). Compared with the Federal and State regulations for air quality (Appendix D), the level of nitrogen dioxide at the WIPP site was not exceeded during the year.

Hydrogen sulfide data as presented in Figure 35 shows that the highest reading occurred on November 2, 1976 , when the concentration reached $0.22 \mu \mathrm{g} / \mathrm{m}^{3}$. The avelaye 24-hour value for the 7 months was $0.11 \mu \mathrm{g} / \mathrm{m}^{3}$ of air. Rased on the 24 .. hour value of $0.22 \mu \mathrm{g} / \mathrm{m}^{3}$, the State standard of $0.003 \mathrm{ppm}\left(4.5 \mu \mathrm{g} / \mathrm{m}^{3}\right)$ for a 1 -hour average was probably not exceeded during the sampling periods.

\footnotetext{
*A filter for removing particulate matter (a pleated paper cartridge in a plastic holder).
} 
Appendix A

\title{
DETERIMINATION OF SULFUR DIOXIDE
}

\author{
Introduction
}

The method described is applicable to the determination of sulfur dioxide in outside ambient air in the concentration range from 0.0005 to $5.0 \mathrm{ppm}$. Sulfur dioxide is absorbed in $0.1 \mathrm{M}$ sodium tetrachloromercurate. The addition of acid-bleached pararosaniline and formaldehyde to the complex ion produces red-purple pararosaniline methylsulfonic acid, which is measured spectrophotometrically at $548 \mathrm{~nm}$.

\section{Reagents}

1. Absorbing Reagent, $0.1 \mathrm{M}$ sodium tetrachloromercurate $(0.04 \mathrm{M})$ Dissolve 10.86 grams of mercuric chloride, 0.066 gram of EDTA (ethylenediaminetetracetic acid, dișodium salt) and 6.0 grams of potassium chloride in 1 litre of distilled water. (Prepare fresh every 6 months.)

2. Sulfamic acid $(0.6 \%)$

Dissolve 0.6 gram of sulfamic acid in $100 \mathrm{~mL}$ of distilled water. (Prepare fresh daily.)

3. Formaldehyde $(0.2 \%)$

Dilute $1 \mathrm{~mL}$ of $36 \%-38 \%$ formaldehyde to $200 \mathrm{~mL}$. (Prepare fresh daily.)

4. Stock Iodine Solution $(0.1 \mathrm{~N})$

Place 12.7 grams of iodine in a $250-\mathrm{mL}$ beaker. Add 40 grams of potassium iodide and $25 \mathrm{~mL}$ of distilled water. Stir until dissolved and dilute to 1 litre. (Store in amber bottle in refrigerator.) 
5. Iodine Solution $(0.01 \mathrm{~N})$

Dilute $50 \mathrm{~mL}$ of stock iodine solution (\#4) to $500 \mathrm{~mL}$ with distilled water. (Store in amber bottle in refrigerator.)

6. Starch Indicator Solution

Dissolve 0.4 gram of soluble starch in $200 \mathrm{~mL}$ of boiling distipled water.

7. Stock Thiosulfate Solution $(0.1 \mathrm{~N})$

Dissolve 25 grams of sodium thiosulfate in a small amount of distilled water in a $1000-\mathrm{mL}$ volumetric flask. Add 0.1 gram of sodium carbonate and dilute to volume. Allow to stand 1 day before standardizing, which consists of the following:

a. Accurately weigh to the nearest $0.1 \mathrm{mg}, 1.5$ grams of primary standard potassium iodate and dilute to $500 \mathrm{~mL}$ with distilled water in a volumetric flask.

b. Pipet $50 \mathrm{~mL}$ of the iodate solution into a $500-\mathrm{mL}$ glass-stoppered flask. Add 2.0 grams of potassium iodide and $10 \mathrm{mI}$ of $1 \mathrm{~N}$ HCl. Stopper flask after 5 minutes and titrate with stock thiosulfate. solution to a pale yellow color. Add $5 \mathrm{~mL}$ of starch solution and continue titration until the blue color disappears.

c. Calculation of the normality of the stock thiosulfate solution:

$$
\begin{aligned}
& N=\frac{W}{M} \times 2.80 \\
& N=\text { normality of thiosulfate } \\
& M=\text { volume of thiosulfate required }(\mathrm{mL}) \\
& W=\text { weight of potassium iodate in grams }(\sim 0.15 \mathrm{gram})
\end{aligned}
$$


8. Sodium Thiosulfate Titrant $(0,01 \mathrm{~N})$

The sodium thiosulfate titrant is prepared by diluting $10 \mathrm{~mL}$ of stock thiosulfate to $100 \mathrm{~mL}$.

Normality $=$ normality of stock solution $\times 0.10$

9. Sulfite Standard Solution

Dissolve 0.30 gram of sodium thiosulfate (or 0.40 gram of sodium sulfite) in $500 \mathrm{~mL}$ of distilled water in a volumetric flask. The exact concentration is determined as follows:

Pipet $50 \mathrm{~mL}$ of $0,01 \mathrm{~N}$ iodine solution (\#5) into each of two 500-mL glass-stoppered flasks. To one flask (Blank) add $25 \mathrm{~mL}$ of distilled water. To the other flask, add $25 \mathrm{~mL}$ of sulfite solution (\#9). Allow to react for 5 minutes, then titrate each with $0.01 \mathrm{~N}$ sodium thiosulf ate solution (\#8) to a pale yellow color. Add $5 \mathrm{mI}$, of starch (\#6) and continue titration until blue color disappears. (This solution contains the equivalent of $320-400 \mu \mathrm{g} / \mathrm{mL} \mathrm{SO}_{2}$.)

10. Working Sulfite/TCM Solution

Pipet $2 \mathrm{~mL}$ of the standard sulfite solution into a $100-\mathrm{mL}$ volumetric flask and dilute to volume with absorbing reagent, $0.04 \mathrm{M}$ (\#1).

Calculatc the $\mathrm{SO}_{2}$ snncentration in the sulfite solution as follows:

$$
\begin{aligned}
\mu \mathrm{gSO}_{2} / \mathrm{mL} & =\frac{(\mathrm{A}-\mathrm{B})(\mathrm{N})(32,000)}{25} \times 0.02 \\
\mathrm{~A} & =\text { volume of thiosulfate for Blank }(\mathrm{mL}) \\
\mathrm{B} & =\text { volume of thiosulfate for Sample }(\mathrm{mL}) \\
\mathrm{N} & =\text { normality of thiosulfate titrant } \\
32,000 & =\text { milliequivalent weight for } \mathrm{SO}_{2}(\mu \mathrm{g})
\end{aligned}
$$




$$
\begin{aligned}
25= & \text { volume of standard sulfite used in } \\
& \text { titration }(\mathrm{mL}) \\
0.02= & \text { dilution factor }
\end{aligned}
$$

This solution is stable for 1 month if kept refrigerated.

11. Pararosaniline Stock Solution $(0.2 \%)$

To a $250-\mathrm{mL}$ volumetric flask add $20 \mathrm{~mL}$ of pararosaniline (Harlcco) - nule the assay \%.- Add an additional $0.2 \mathrm{~mL}$ of pararosaniline for each percent the solution assays below $100 \%$.

'i'hen add $25 \mathrm{~mL}$ of $3 \mathrm{M}$ phosphoric acid* and dilute to volume with distilled water. (Reagent.is stable for at least 9 months.)

*3M phosphoric acid is prepared by adding $20 \mathrm{~mL}$ of concentrated (85\%) $14.7 \mathrm{M}$ phosphoric acid to $60 \mathrm{~mL}$ of water and diluting to $100 \mathrm{~mL}$.

\section{Preparation of Sulfur Dioxide Standard Curve}

1. Pipet $0,0.5,1.0,1.5,2.0 \mathrm{~mL}$ of sulfitc-TCM solution (\#10) into $25-11 \mathrm{~L}$ volumetric flasks : and dilute to $10 \mathrm{~mL}$ with absorbing reagent (\#1).

2. Add $1 \mathrm{~mL}$ of $0.6 \%$ sulfamic acid (H3) to eacl flask and allow to react for 10 minutes (to destroy any nitrite formed by oxides uf nitrogen). Add $2 \mathrm{~mL}$ of $0.2 \%$ formaldehyde solution (\#3) and $5 \mathrm{~mL}$ of pararosaniline stock solution (\#11). Dilute to volume with distilled water:

3. After 30 minutes determine the absorbance of the standard solutions spectro-photometrically at $548 \mathrm{~nm}$ using zero standard as the Blank.

4. The concentration of $\mathrm{SO}_{2}$ in each flask is determined as follows:

$\mu \mathrm{g} \mathrm{SO} 2 / \mathrm{mL}$ in sulfite/TCM solution (\#10) $\times \mathrm{mL}$ added 
5. Prepare a standard curve by plotting the concentrations in $\mu \mathrm{g}$ of $\mathrm{SO}_{2} / \mathrm{mL}$ against the respective $\% \mathrm{~T}$ readings on graph paper.

$$
\text { Analysis of } \mathrm{SO}_{2} \text { Air Samples }
$$

1. Place $50 \mathrm{~mL}$ of absorbing reagent (\#1) into black bubkler.

2. Sample at $200 \mathrm{~mL} / \mathrm{min}$ for 24 hours.

3. After sampling, dilute sample to $50 \mathrm{~mL}$, if needed, with absorbing reagent (\#1).

4. Pipet $5 \mathrm{~mL}$ of the sample into a $25-\mathrm{mL}$ volumetric flask. Add $5 \mathrm{~mL}$ of absorbing reagent (\#1). Delay analysis for 20 minutes to allow any ozone to decompose.

5. For each set of determinations, prepare a reagent Blank by adding $10 \mathrm{~mL}$ of absorbing reagent (\#1) to a $25-\mathrm{mL}$ volumetric flask.

6. To each volumetric flask add $1 \mathrm{~mL}$ of $0.6 \%$ sulfamic acid (\#2) and allow to react 10 minutes to destroy the nitrate formed from the oxides of nitrogen.

7. Add $2 \mathrm{~mL}$ of $0.2 \%$ formaldehyde (\#3) and $5 \mathrm{~mL}$ of pararosaniline (\#11). Dilute to volume with distilled water.

8. After 30 minutes determine the $\% \mathrm{~T}$ of the samples at $548 \mathrm{~nm}$ against the reagent Blank.

9. Read the concentration in $\mu \mathrm{g} \mathrm{SO_{2 }}$ from the standard curve.

Calculation of volume of air sampled:

$$
v=\left(\frac{T_{1}+F_{2}}{2}\right) \times T \times 6 \times 10^{-5}
$$




$$
\begin{aligned}
\mathrm{v} & =\text { volume of air sampled }\left(\mathrm{m}^{3}\right) \\
\mathrm{F}_{1} & =\text { initial flow rate }\left(\mathrm{cm}^{3} / \mathrm{min}\right) \\
\mathrm{F}_{2} & =\text { final flow rate }\left(\mathrm{cm}^{3} / \mathrm{min}\right) \\
\mathrm{T} & =\text { sampling interval (hours) } \\
6 \times 10^{-5} & =\text { conversion factor. }
\end{aligned}
$$

Calculation of $\mathrm{SO}_{2}$ concentration in air:

$$
\begin{aligned}
\mu \mathrm{gO}_{2} / \mathrm{m}^{3} & =\frac{\mathrm{A} \times 50}{\mathrm{~V}} \\
\mathrm{~A} & =\mu \mathrm{g} \mathrm{SO} 2 / \mathrm{mL} \text { read from standard curve } \\
50 & =\text { volume of absorbing reagent }(\mathrm{mL}) \\
\mathrm{V} & =\text { volume of air sampled }\left(\mathrm{m}^{3}\right)
\end{aligned}
$$

To convert $\mu \mathrm{g} \mathrm{SO}_{2} / \mathrm{m}^{3}$ to $\mathrm{ppm} \mathrm{SO}_{2}$

$$
\mathrm{ppm} \mathrm{SO} \mathrm{SO}_{2}=\mu \mathrm{g} \mathrm{SO}_{2} / \mathrm{m}^{3} \times 3.82 \times 10^{-4}
$$


Appendix B

DETERMINATION OF NITROGEN DIOXIDE

Introduction

The method described is applicable to the determination of nitrogen dioxide in outside ambient air in the concentration range from 0.01 to $0.4 \mathrm{ppm}$. Nitrogen dioxide is absorbed in sodium hydroxide to form a stable solution of sodium nitrite. The nitrite ion is reacted with phosphoric acid, sulfanilamide and N-1-naphthylene diamine dihydrochloride and determined spectrophotometrically at $540 \mathrm{~nm}$.

\section{Reagents}

1. Absorbing Solution $(0.1 \mathrm{~N})$

Dissolve 4.0 grams of sodium hydroxide in distilled water in a 1-litre volumetric flask and dilute to volume.

2. Sulfanilamide

Dissolve 20 grams of sulfanilamide in $700 \mathrm{~mL}$ of distilled water. Add, with mixing, $50 \mathrm{~mL}$ of concentrated phosphoric acid $(85 \%)$ and dilute to one litre. (Stable for one month if refrigerated.)

3. NEDA solution $(0.1 \%)$

Dissolve 0.5 gram of $\mathrm{N}$-1-naphthylene diamine dihydrochloride in 500 $\mathrm{mL}$ of distilled water. (Stable for one month if refrigerated and protected from light.)

4. Hydrogen Peroxide

Dilute $0.2 \mathrm{~mL}$ of $30 \%$ hydrogen peroxide to $250 \mathrm{~mL}$ with distilled water. (Stable for one month if protected from light.) 
5. Standard Nitrite Solution

Dissolve sufficient sodium nitrite in one litre of distilled water so that the solution contains $1000 \mu \mathrm{g} \mathrm{NO} / \mathrm{mL}$. The amount of sodium nitrite is calculated as follows:

$$
\begin{aligned}
\mathrm{NaNO}_{2}(\mathrm{gm}) & =\frac{1.5}{\mathrm{~A}} \times 100 \\
\mathrm{~A} & =\operatorname{assay}(\%) \\
1.5 & =\text { factor to convert } \mathrm{NO}_{2} \text { into } \mathrm{NaNO}_{2}
\end{aligned}
$$

6. Working PNlrite solution

Dilute $6 \mathrm{~mL}$ of the standard nitrite oolution ( 45$)$ to $200 \mathrm{~mL}$ with absorbing reagent (\#1) in a volumetric flask. This solution contains $25 \mu \mathrm{g}$ $\mathrm{NO}_{2} / \mathrm{mL}$.

Preparation of the $\mathrm{NO}_{2}$ Standard Curve

1. Pipet $0,1,3,5$ aild $13 \mathrm{~mL}$ of the working nitrite solution (\#6) into 25-, 50-, 50-, 100-, and 250-mL volumetric flasks and dilute each to volume with absorbing solution (\#1). These solutiuns contain 0 , $0.5,1.0,1.25$, and $1.5 \mu \mathrm{g}$ of $\mathrm{NO}_{2} / \mathrm{mL}_{2}$, respectively.

2. Pipet $10 \mathrm{~mL}$ of each of the above standards into $40-\mathrm{mL}$ test tubes.

3. Add $1 \mathrm{~mL}$ of hydrogen peroxide solution (\#4), $10 \mathrm{~mL}$ of sulfantlamide (\#2) and 1.4 mL of NEDA solution (\#3) to each tube, mixing thoroughly after tlie addition of each reagent.

4. After a 10-minute color development interval, transfer solution to small colorimetric tubes and measure the absorbance at $540 \mathrm{~nm}$ against the zero standard.

5. Plot $\mu \mathrm{g} \mathrm{NO} 2 / \mathrm{mL}$ versus $\% \mathrm{~T}$. 
1. Add $50 \mathrm{~mL}$ absorbing reagent (\#1) to the bubbler.

2. Draw air sample at $200 \mathrm{~mL}$ per minute for 24 hours.

3. Replace any water lost by evaporation during sampling.

4. Pipet $10 \mathrm{~mL}$ of collected sample into $40-\mathrm{mL}$ test tube.

5. Add $1 \mathrm{~mL}$ of hydrogen peroxide solution (\#4), $10 \mathrm{~mL}$ of sulfanilamide (\#2) and $1.4 \mathrm{~mL}$ of NEDA solution (\#3). Mix thoroughly after addition of each reagent.

6. Prepare a Blank in the same manner, using $10 \mathrm{~mL}$ of absorbing agent (\#1) in place of sample.

7. After a 10-minute color development interval, transfer solution to colorimeter tubes and measure absorbance at $540 \mathrm{~nm}$ against the Blank.

8. Determine the $\mu \mathrm{g} \mathrm{NO}_{2} / \mathrm{mL}$ from the standard curve.

Calculation of volume of air sampled:

$$
\begin{aligned}
\mathrm{V} & =\left(\frac{F_{1}+F_{2}}{2}\right) \times \mathrm{T} \times 6 \times 10^{-5} \\
\mathrm{~V} & =\text { volume of air sampled }\left(\mathrm{m}^{3}\right) \\
\mathrm{F}_{1} & =\text { initial flow rate }\left(\mathrm{cm}^{3} / \mathrm{min}\right) \\
\mathrm{F}_{2} & =\text { final flow rate }\left(\mathrm{cm}^{3} / \mathrm{min}\right) \\
\mathrm{T} & =\text { sampling interval (hours) } \\
6 \times 10^{-5} & =\text { conversion factor }
\end{aligned}
$$


Calculation of $\mathrm{NO}_{2}$ concentration in air:

$$
\begin{aligned}
\mu \mathrm{g} \mathrm{NO}_{2} / \mathrm{m}^{3} & =\frac{\mathrm{A} \times 50}{\mathrm{~V} \times 0.35} \\
\mathrm{~A} & =\mu \mathrm{g} \mathrm{NO} 2 / \mathrm{mL} \\
50 & =\text { volume of absorbing reagent }(\mathrm{mL}) \\
\mathrm{V} & =\text { volume of air sampled }\left(\mathrm{m}^{3}\right) \\
0.35 & =\text { sampling train efficionoy }
\end{aligned}
$$

To convert $\mu \mathrm{g} \mathrm{NO}_{2} / \mathrm{m}^{3}$ to ppm $\mathrm{NO}_{2}$

$$
\text { ppin } \mathrm{NO}_{2}=\mu \mathrm{g} \mathrm{NO}_{2} / \mathrm{m}^{3} \times 5.32 \times 10^{-4}
$$


Appendix C

DETERMINATION OF HYDROGEN SULFIDE

\section{Reagents}

1. $0.5 \mathrm{~N}$ Sodium Hydroxide

Dissolve 2 grams of sodium hydroxide in $100 \mathrm{~mL}$ of distilled water.

2. Cadmium Chloride

Dissolve 20 grams of cadmium chloride in $900 \mathrm{~mL}$ of distilled water.

3. Absorbing Reagent

Add $20 \mathrm{~mL}$ of $0.5 \mathrm{~N} \mathrm{NaOH}$ to $900 \mathrm{~mL}$ of cadmium chloride solution and mix well.

4. $0.005 \mathrm{~N}$ Iodine Solution

Dilute $0.01 \mathrm{~N}$ iodine solution $1: 1$ with distilled water.

5. $0.005 \mathrm{~N}$ Sodium Thiosulfate Titrant

Dilute $0.01 \mathrm{~N}$ thiosulfate solution $1: 1$ with distilled water.

6. Starch Indic ator Solution

Dissolve $0.4 \mathrm{gram}$ of soluble starch in $200 \mathrm{~mL}$ of boiling distilled water.

Analysis

1. Place $50 \mathrm{~mL}$ of absorbing reagent into glass bubbler and sample for 24 hours at a known air--llow rate. 
2. After sampling, transfer sample to a $250-\mathrm{mL}$ titration flask. Rinse bubbler with 5-10 $\mathrm{mL}$ of distilled water and add to titration flask.

3. Prepare a Blank by adding $50 \mathrm{~mL}$ of absorbing solution to a titration flask.

4. Add $15 \mathrm{~mL}$ of concentrated $\mathrm{HC} 1$ to both sample and Blank and mix well.

5. Add $25 \mathrm{~mL}$ of $0,005 \mathrm{~N}$ standard iodine solution to both Blank and sample solutions. Back titrate the excess iodine with $0.005 \mathrm{~N}$ sodium thioaulfatc using star.clı ds an indicator.

\section{Calculations}

1. Subtract the $\mathrm{mL}$ required for sample analysis from the $\mathrm{mL}$ required for Blank analysis and multiply the difference by 84.6. This corresponds to $\mu \mathrm{g} \mathrm{H}_{2} \mathrm{~S}$ in the sample.

2. Multiply the sampling rate by the sampling interval; multiply this by 0.06 to express volume in cubic metres.

3. Divide $\mu \mathrm{g} \mathrm{H}_{2} \mathrm{~S}$ in the sample by the volume of air sampled for final concentration of $\mu \mathrm{g} \mathrm{H}_{2} \mathrm{~S} / \mathrm{m}^{3}$.

4. The following equation describes the above procedures:

$$
\begin{aligned}
\frac{\mu \mathrm{H} \mathrm{H}_{2} \mathrm{~S}}{\mathrm{~m}^{3}} & =\frac{(\mathrm{A}-\mathrm{B}) 84 . \mathrm{RT} 0.06}{\Lambda}=\mathrm{mL} \text { of titrant required for blank }
\end{aligned}
$$


$\mathrm{B}=\mathrm{mL}$ of titrant required for sample

$\mathrm{R}=$ sampling rate (litres $/ \mathrm{min}$ )

$\mathrm{T}=$ sampling interval (hours). 


\section{Appendix D}

AIR QUALITY STANDARDS - APRIL 28, 1971

$$
\text { Federal Regulations - April 30, } 1971
$$

$\mathrm{SO}_{2}$

(Primary)

$\mathrm{SO}_{2}$

(Secondary)

$\mathrm{CO}$

(Primary)

(Secondary)

Oxidant

(Primary)

(Secondary)

$\mathrm{NO}_{2}$

(Primary)

(Secondary)

Particulate

(Frimary)

Particulate

(Sec ondary)

$$
\begin{array}{r}
80 \mu \mathrm{g} / \mathrm{m}^{3} \\
365 \mu \mathrm{g} / \mathrm{m}^{3}
\end{array}
$$

$60 \mu \mathrm{g} / \mathrm{m}^{3}$

$260 \mu \mathrm{g} / \mathrm{m}^{3}$

$1300 \mu \mathrm{g} / \mathrm{m}^{3}$

$10 \mathrm{mg} / \mathrm{m}^{3}$

$40 \mathrm{mg} / \mathrm{m}^{3}$

$160 \mu \mathrm{g} / \mathrm{m}^{3}$

(0.08 ppm)

(0.02 ppm)

(0.1 ppm)

$(0.5 \mathrm{ppm})$

( 9 ppm)

(35 ppm)

$\max 8 \mathrm{hr}$

$\max 1 \mathrm{hr}$

(1x)

$(1 \mathrm{x})$

annual arithmetric mean

$\max 24 \mathrm{hr} \quad(1 \mathrm{x})$

$\max 3 \mathrm{hr} \quad(1 \mathrm{x})$

$\max 1 \mathrm{hr}$

$\max 1 \mathrm{hr} \quad(1 \mathrm{x})$

(0.05 ppm)

annual arithmetric mean

annual geometric mean

$\max 24 \mathrm{hr} \quad(1 \mathrm{x})$

annual geometric mean

$\max 24 \mathrm{hr} \quad(1 \mathrm{x})$ 
A. Maximum allowable concentration of total suspended particulate:

$\begin{array}{lr}\text { 24-hour average } & 150 \mu \mathrm{g} / \mathrm{m}^{3} \\ 7 \text {-day average } & 110 \mu \mathrm{g} / \mathrm{m}_{3}^{3} \\ 30 \text {-day average } & 90 \mu \mathrm{g} / \mathrm{m}_{3} \\ \text { Annual geometric mean } & 60 \mu \mathrm{g} / \mathrm{m}^{3}\end{array}$

B. Air contaminants - maximum allowable concentration:

Sulfur Dioxide $\left(\mathrm{SO}_{2}\right)$

24-hour average

Annual arithmetic mean

$0.10 \mathrm{ppm}$

$0.02 \mathrm{ppm}$

$260 \mu \mathrm{g} / \mathrm{m}_{3}^{3}$

$53 \mu \mathrm{g} / \mathrm{m}^{3}$

Hydrogen Sulfide $\left(\mathrm{H}_{2} \mathrm{~S}\right)$
1 -hour average
$0.003 \mathrm{ppm}$
$4.5 \mu \mathrm{g} / \mathrm{m}^{3}$

Carbon Monoxide (CO)
8-hour average
$8.7 \mathrm{ppm}$
1 -hnir average
$13.1 \mathrm{ppm}$

Nitrogen Dioxide $\left(\mathrm{NO}_{2}\right)$

24-hour average

$0.10 \mathrm{ppm}$

Annual arithmetic mean

$0.05 \mathrm{ppm}$

$220 \mu \mathrm{g} / \mathrm{m}_{3}^{3}$ $100 \mu \mathrm{g} / \mathrm{m}^{3}$

Photochemical Oxidant $\left(\mathrm{O}_{3}\right)$
1-hour average
$0.06 \mathrm{ppm}$ 


\section{REFERENCES}

1. D. B. Yeates, A. S. Goldin, and D. W. Moeller, "Natural Radiation in the Urban Environment, " Nuclear Safety, 13:275-286 (July-August 1972)

2. NCRP (1975). National Council on Radiation Protection and Measurements. Natural Background Radiation in the United States, NCRP Report No. 45, National Council on Radiation Protection and Measurements, Washington.

3. W. Herbst, "Investigations of Environmental Radiation and Its Variability," Proceedings of the 1st International Symposium on the Natural Radiation Environment, Houston, Texas, 1963 (1964) pp. 781-796.

4. K. O'Brien and J. E. Mc Laughlin, "The Radiation Dose to Man from Galactic Cosmic Rays," Health Physics, 22:225-232 (March 1972).

5. J. A. MacKaller, "Aeroradioactivity Survey and Geology of the Gnome (Carlsbad) Area, New Mexico and Texas (ARMS-1); USAEC Document CEX-59.4.24 (1965).

6. A. W. Klement, Jr., C. R. Miller, R. P. Minx, and B. Shleien, Estimates of Ionizing Radiation Doses in the United States 1960-2000, EPA Report ORP/CSD 72-1, U.S. Environmental Protection Agency, Rockville, MD (1972).

7. Air Sampling Instruments for Evaluation of Atmospheric Contaminants, 4th edition, American Conference of Governmental Industrial Hygienists (1972).

\section{BIBLIOGRAPHY}

1. Adams, J. A. S., and W. M Lowder, The Natural Radiation Environment, The University of Chicago Press, Chicago (1964).

2. Pertsov, L. A., The Natural Radioactivity of the Biosphere, Israel Program for Scientific Translations, Jerusalem (1967).

3. Oakley, D. T., Natural Radiation Exposure in the United States, EPA Report ORP/SID 72-1, U.S. Environmental Protection Agency, Washington (1972).

4. NCRP (1976). National Council on Radiation Protection and Measurements. Environmental Radiation Measurements, NCRP Report No. 50, National Council on Radiation Protertion and Measurements, Washington. 


\section{DISTRIBUTION:}

Delacroix Davis (25)

Nuclear Materials and Waste

Management Division, ERDA / A LO

Albuquerque, NM 87115

Amax Chemical Corporation

P. O. Box 279

Carlsbad, NM 88220

Ray Bahm, Bureau of Engineering Research University of New Mexico

Albuquerque, NM 87131

Dr. Ken Barnett, Physical Science Lab New Mexico State University

P.O. Box 3548

Las Cruces, NM 88003

Ivan Bennett, Department of Geography

Univer sity of New Mexicu

Albuquerquo, NM 87131

Dr. Garry Donart

New Mexico State University

P.O. Box 3548

Las Cruces, NM 88003

Duval Corporation

P.O. Box 511

Carlsbad, NM 88220

Attn: Mike Scroggins

A. L. Gennarn

Eastern New Mexico University

Portales, NM 88130

Edward Groth, Jr.

New Mexico State University

P. O. Box 3548

Las Cruces, NM 88003

International Minerals and Chemical Corp. Mine Site

Carlsbad, NM 88220

LaM ar Johnson, H-8

University of California

Los Alamos Scientific Laboratory

P.O. Box 1663

Los Alamos, NM 87544

Ker-McGee Chemical Company

P.O. Box 1120

Carlsbad, NMI 88220

Mississippi Potash. Inc.

P.O. Box 101

Carlsbad, NM 88220

National Potash Company

P. O. Box 731

Carlsbad, NM 88220

New Mexico Bureau of Mines and

Mineral Resources

Socorro, NM 87801
New Mexico Environment Improvement Agency (5)

P.O. Box 2348

Santa Fe, NM 87501

Attn: George Scudella

Russ Rhoades

Ted Wolff

Ken Hargis

Dick Burgard

New Mexico Governor's Energy Resources Board 350 E. Palace

Santa Fe, NM 87501

Attn: Larry Kehoe

New Mexico Scientific Laboratory System

700 Camino De Salud NE

Albuquerque, NM 87110

Attn: Aaron Bond

New Mlexiço Sttate Engineer

Bataan Building

Santa Fe, NM 87501

Attn: Steve Reynolds

New Mexico State Geologist

P.O. Box 2860

Santa Fe, NM 87501

Attn: Imory C. Arnold

New Mexico State Planning Office

505 Don Gaspar

Santa Fc, NM 87503

Attn: Ms Kate Wicks

Potash Company of America

$\mathrm{P}: \mathrm{O}, \mathrm{Box} 31$

Carlsbad, NM 88220

Dr. Marvin H. Wilkening (4)

Graduate Office

New Mexico Institute of Mining \& Technology

Socorro, NM 87801

Dr. Bruce Wilson

New Mexico State University

P.O. Box 3805

Las Cruces, NM 88002

Dr. Ronald Lantz

1201 Dairy Ashford

Suite 200

Houston, TX 77079

1000 G. A. Fowler

1100 C. D. Broyles

1120 G. E. Hansche

1125 G. L. Ogle

Attn: J. T. McIlmoyle

1130 H. E. Viney

1140 W. D. Weart

1141 L. R. Hill

1141 A. R. Sattler

1142 L. W. Scully

1142 J. E. Magruder (5)

1143 J. W. McKiernan 
DISTRIBUTION: (cont)

$1150 \mathrm{~J} . \mathrm{W}$. Banister

1151 M. L. Merritt (5)

1336 J. K. Cole

Attn: Ann E. McIntyre

R. B. Powell

3300 S. P. Bliss

3310 W. H. Kingsley

3311 D. R. Parker

3312 W. D. Burnett

3313 G. E. Tucker, Jr.

5400 A. W. Snyder

5443 B. D. Zak

Attn: H. W. Church

8266 E. A. Aas

3141 C. A. Pepmueller (Actg) (5)

3151 W. L. Garner (3)

For ERDA/TIC

ERDA / TIC (25)

(R. P. Campbell, 3172-3) 